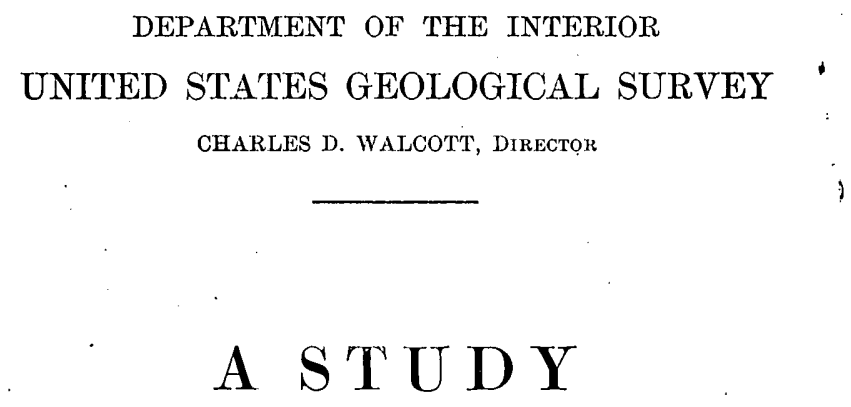

OF THF

\title{
FAUNA OF THE HAMILTON FORMATION OF THE CAYUGA LAKE SECTION IN CENTRAL NEW YORK.
}

\author{
BY \\ HERDMAN FITZGERALD CLELAND
}

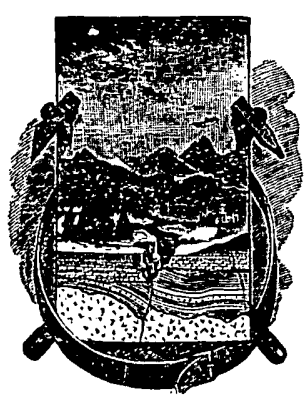

W ASHINGTON

GOVERNMENT PRINTING OFFICE 

Tetter of thange.

Introduction, by Henry S. Willian

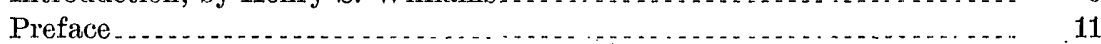

Chapter I. General description and general geology of Cayyuga Lake region_ $\quad 13$

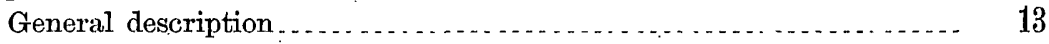

General geology $\ldots . . .14$

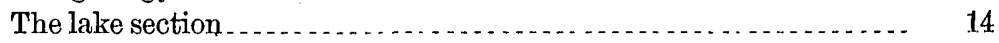

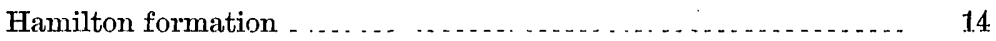

Encrinal beds ..............

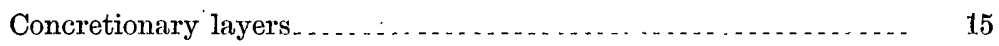

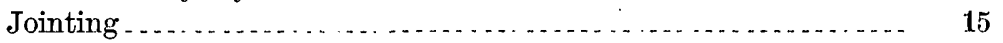

Tully fold $\ldots \ldots \ldots \ldots \ldots \ldots \ldots$

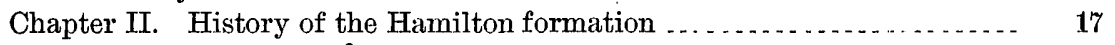

McClure .

Eaton

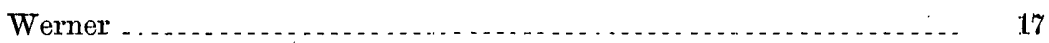

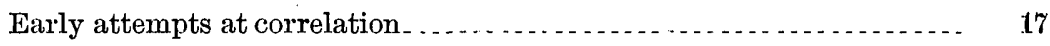

Search for coal ... $\ldots \ldots \ldots \ldots . \ldots 17$

Conrad and Hall $\ldots \ldots \ldots$

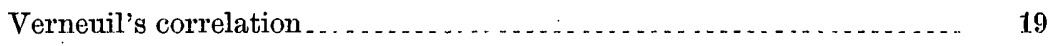

Renevier's correlation $\ldots \ldots \ldots \ldots$

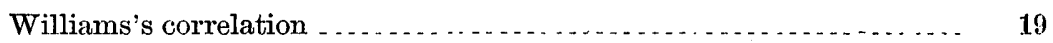

South American Hamilton . . . . . . . . . . . . . . . . . . . . . . . . . . . . . 19

Chapter III. Descriptions of the fossiliferous zones .................. 20

Hamilton-Onondaga (Corniferous) zone ...................... 20

First Leiorhynchus zone (Marcellus shale) ...... ............. 22

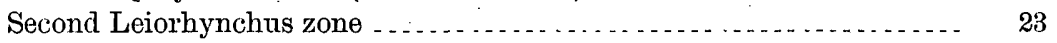

First Terebratula zone (Basal limestone of Clarke) - . . . .

Third Leiorhynchus zone ....................................... 25

Michelinia zone (provisionally) . .

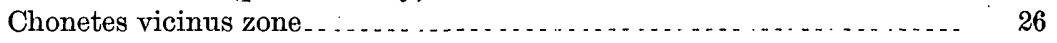

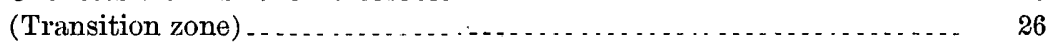

First Cypricardella bellistriata-Athyris spiriferoides zone .......... 26

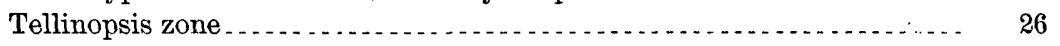

Second Cypricardella bəllistriata-Athyris spiriferoides zone .......... 27

Second Terebratula zone (Encrinal beds) _.................... 27 .

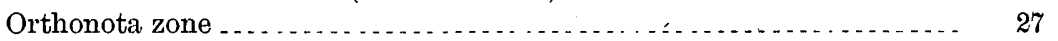

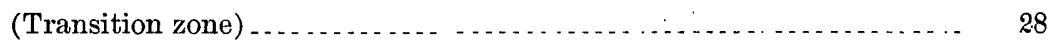

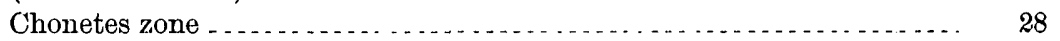

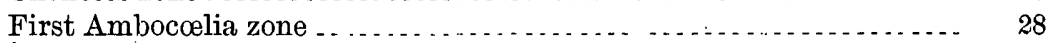

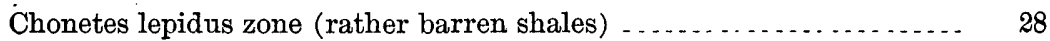


Chapter III, Description of the fossiliferous zones-Continued. Page.

Second Ambocolia zone....................................... 29

Stropheodonta-Coralline zone

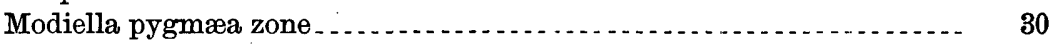

Ambocœlia præumbona zone............. 30

Orbiculoidea or modified Leiorhynchus zone................... 30

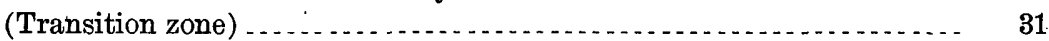

Spirifer-Atrypa zone .

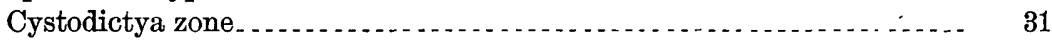

Explanation of diagrams on Pl. V . . . . . . . . . . . . . . . . . . . . . . 32

Chapter IV. Annotated list and classification of species found in the

Hamilton formation of the Cayuga Lake section

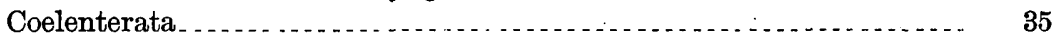

Anthozoa-Actinozoa $\ldots . . . \ldots \ldots$

Echinodermata ............ 38

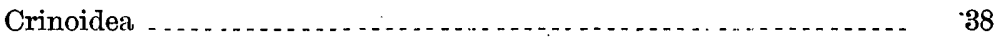

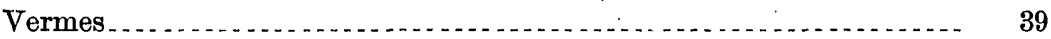

Molluscoidea . . . .

Bryozoa $\ldots$

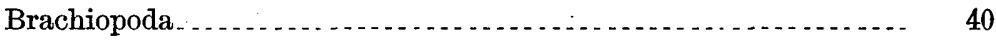

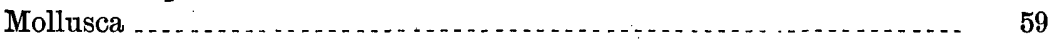

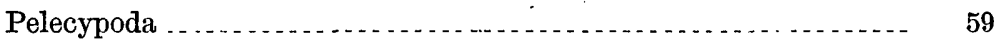

Gasteropoda.

Cephalopoda..................... 77

Arthropoda $\ldots \ldots$

Crustacea $\ldots \ldots \ldots$

Plantæ ... . . . . . . . . . . . . .

Chapter V. Comparison of the Cayuga Lake section with other sections of the Hamilton formation. . . 83

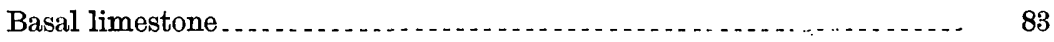

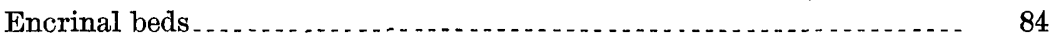

Gasteropoda

Use of the terms " upper" and "lower" Hamilton faunas......... $\quad 86$

Explanation of diagram, fig. 3 .

Chapter VI. Conclusions......................................... 89

Chapter VII. Bibliography of literature used in preparation of this paper.. $\quad 92$

Appendix. Table showing vertical distribution of faunal zones, with their contained faunules, in the Hamilton formation of Cayuga Lake, New York

Index $\ldots \ldots \ldots$ 


\section{L U S T R A T I O N S.}

Page.

PLate I. Geologic map of Cayuga Lake region . ......................... 14

II. Jointing in the Upper Hamilton shales at Shurger Glen (fall over the Tully limestone) .................................. 16

III. $A$, Tully limestone south of Shurger Glen; $B$, Encrinal beds showing dip to the south, south of Shurger Glen ................. 18

IV. Alternation of impure limestones and shales above the Onondaga beds at Union Springs ........................................

V. $A$, Diagram showing the relative abundance of Pelecypoda and Brachiopoda in the Cayuga Lake section; $B$, Diagram showing the relative abundance of individuals and species in the Cayuga Lake section

Fiq. 1. Cayuga Lake section . .

2. Zones in Cayuga Lake section . . . . . . . . . . . . . . . . . . . . . . .

3. Diagram showing the distribution of fossils of the Hamilton formation throughout New York State 



\section{LETTER OF TRANSMITTAL.}

Yale University,

New. Haven, Conn., June 28, 1902.

SIR: I have the honor to transmit herewith, for publication as a bulletin of the United States Geological Survey, the manuscript of a paper entitled A Study of the Fauna of the Familton Formation of the Cayuga Lake Section in Central New York, prepared at my suggestion by Herdman Fitzgerald Cleland.

Respectfully, yours,

Henry ShaleR WiLliams, Geologist and Paleontologist.

Hon. Charles D. Walcott,

Director of United States Geological Survey. 



\title{
IN TR OD UCTION.
}

\author{
By Henry Shaler Williams.
}

The following paper is a contribution to the knowledge of the fossil faunas of the Devonian of the United States. It was begun by Mr. Cleland as a piece of research work in the course of study for the doctorate degree at Yale University, and was used as a thesis in taking the degree of doctor of philosophy in June, 1900. During the summer of 1901 some additional work was put on it, based upon more extended field work.

The value of the investigation consists chiefiy in the statistics it furnishes as to the approximate composition of each of the successive faunules making up the total fauna occupying the Hamilton formation of central New York. In it account is given of the species obtained in a careful and full examination of every foot of the section from the top of the Onondaga (Corniferous) limestone to the base of the Tully limestone, both of which are well marked in the Cayuga Lake section, thus constituting definite limits for the Hamilton formation of this particular region.

All the fossiliferous zones (seventy-six in number) were examined, and upon analysis of the faunules of each zone those which were so closely alike as to signify practically the same set of species, associated in the same biological equilibrium of relative abundance, were grouped together, constituting in all twenty-five separate faunules. These may properly be described as the faunules of the twenty-five successive hemeræ into which the Hamilton epoch of this section may be distinguished by its fossils. These faunules are associated with more or less definite changes in the character of the sediments in which they were buried. The separate divisions of the formation thus recognized by slight differences in faunal composition as well as in lithologic constitution may be called zones. The Hamilton formation, its fauna, and the particular section here studied are well known to paleontologists; so that the species can be easily recognized and listed. In making the collections special attention was given to the discovery of the relative abundance of the species found associated together in each rock stratum. Direction was given to collect the fossils as near as possible in the proportion of numbers presented by the natural occurrence in the rocks. Instead of attempting to dis- 
cover rare species, the purpose was to let the preserved collection represent as perfectly as possible the natural proportion of association. The working up of the collection was made to express this natural proportion expressed by the species.

The identification of species is probably always affected more or less by personal judgment. In order to make the statistics of the greatest relative value, therefore, no attempt was made to criticise these personal elements in the author; and while it is probable that another worker dealing with the same specimens would not reach absolutely identical listing of species, it is probable that the errors, if any, from inaccuracy of specific identification are so small relatively as to not disturb the statistical value of the facts recorded. Further and more exhaustive search, also, may be expected to considerably modify the statistics here given; but even this fact does not detract from the value of those here recorded: The more refined the analyses become the more perfect will be our knowledge of faunal compositions. The present investigation is a step in the direction of attaining the fullest possible perfection in recording faunal statistics, and in making these faunal analyses as perfect as they can be made, toward which end the contributions of many workers will be needed. With such statistics in hand we may hope to understand better the laws of evolution as affected by and related to the varying conditions of environment and time.

It will be noticed that the thickness' of the Hamilton, as measured by Prosser in the Ithaca well, is 1,224 feet-that is, between the top of the Onondaga (Corniferous) limestone and the base of the Tully limestone. The exact thickness was not determined by the author. The reason for this is that the great thickness and similarity in the character of the rock of Zones $B$ and $C$ made the accurate measurement of these zones impossible. This is shown in the section (fig. 2) by broken lines. Nevertheless it is believed that the discrepancy does not affect the accuracy of the succession of the fossiliferous zones recorded in this paper. Attention is here called to the fact in order to show how difficult it is to make exact correlation for short distances when the sediments are of similar composition and structure and the general fauna is the same. For the purpose of ascertaining the exact thickness of each zone, a continuous section is necessary, but a long series of shorter sections, where the dip is slight, offers the advantage of a greater number of exposures of the rocks for the collection of the fossils. It is hoped that the present sample of what can be done in the way of an historical study of a fossil fauna may inspire other workers to make similar studies of the rocks in their own localities for comparison and demonstration of the geographical as well as the geological modifications of fossil faunas. 


\section{PREF A CE.}

The material for this study was collected during three months of the summer of 1899 and during May, 1901, from the Hamilton formation exposed along the east side of Lake Cayuga and the west side of Seneca Lake. Commencing at the Onondaga (Corniferous) limestone, an attempt was made to collect the complete faunule from each zone throughout the entire Hamilton formation up to the Tully limestone.

In the identification of the fossils the principle has been followed that unless absolutely necessary no new species or varieties should be described, but that all doubtful specimens should be referred to species already figured.

The writer is indebted to Prof. H. S. Williams for many helpful suggestions concerning methods of work. 



\section{A STUDY. OF THE FAUNA OF THE HAMILTON FORMA- TION OF THE CAYUGA LAKE SECTION IN CENTRAL NEW YORK.}

By Herdman Fitzgerald Cleland.

\section{CHAPTER I.}

\section{GENERAL DESCRIPTION AND GENERAL GEOLOGY OF CAYUGA LAKE REGION.}

GENERAL DESCRIPTION.

The region studied is about 70 miles west of the center of New York State, and extends across about one-third of the State from north to south, the center of the region being nearly in the center of the north-south line. Cayuga Lake, along the east side of which the material for this study was collected, is one of the so-called "finger lakes" of the State, and, with its outlet, forms the boundary between Seneca and Cayuga counties.

In the western two-thirds of the State the strata stirike in an eastwest direction and dip to the south. Because of this southerly dip it is possible for one to see a large part of the Paleozoic section in a comparatively short distance-in passing from north to south. The Cayuga Lake region itself embraces all of the formations between and including the Salina and the Ithaca.

This region is overlain by glacial drift, which hides the rock, except where worn away by erosion. Almost every stream that enters the lake has cut a deep gorge through the drift and into the shale, making excellent exposures. The gorges thus formed often have banks of shale 100 feet or more in height. In all of these creeks there are from one to four falls, the highest of which are caused by four strata of limestone and the hard sandstones or flags of the Portage. A description of Shurger Glen, about 5 miles from the south end of the lake, will, in a general way, answer for all the streams flowing into the lake, the only difference being that the streams farther down the lake do not flow over the Tully limestone, Portage sandstone, etc., 


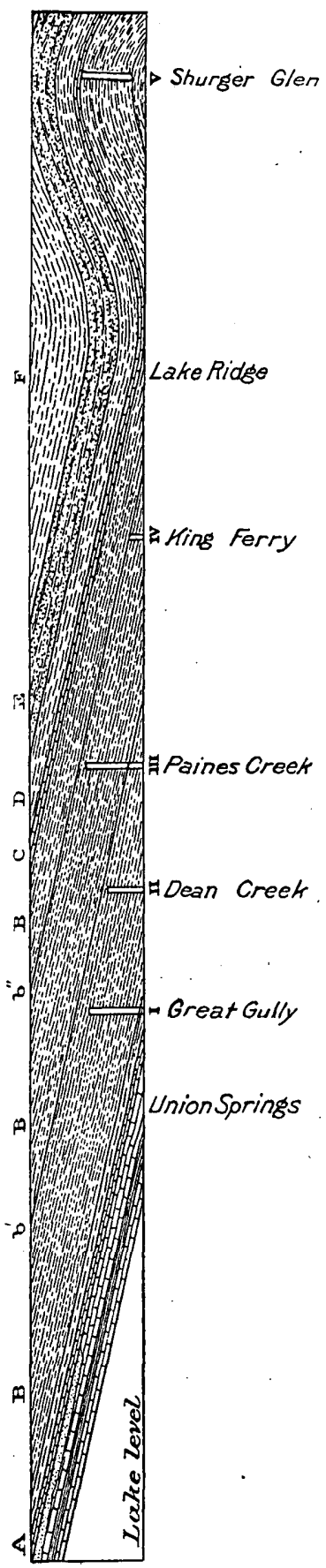

FIG. 1,-Cayuga Lake section. A, Marcellus shale; B, Hamilton for mation; $b^{\prime}$, limestone of zone D; sandy toward the top and closes with a very $b^{\prime \prime}$ Encrinal beds; C, Tully lime- hard, impure limestone. The Marcellus, as stone; D, Genesee shale; E, Portage; F, Ithaca. and consequently have fewer falls. In Shurger Glen there are four sets of falls. The first, nearest the lake, about 30 feet high, is caused by the Encrinal beds (limestone); the second, by a hard shale; the third, by the Tully limestone; and the fourth, by the Portage. In Paines Creek near Aurora the Tully and Portage have been eroded away, leaving the Encrinal and the hard calcareous shales of Zone D at Moonshine to form the fall. In the creeks at Farleys the upper hard limestone capping the Marcellus shale, Zone B, forms the falls.

\section{GENERAL GEOLOGY.}

The lake section.-In traveling from the village of Cayuga to Ithaca one passes over and can collect from, (1) the Eurypterus beds (Rondout limestone or Waterlime), (2) black gypsum (probably Rondout limestone), (3) Stromatopora beds (Manlius limestone ${ }^{a}$ ), (4) Oriskany sandstone (this formation has a maximum thickness here of 4 feet 10 inches and thins out to nothing in less than a mile, leaving the Onondaga (Corniferous) in contact with the Lower Helderberg), (5) Onondaga limestone, (6) Marcellus shales, (7) Hamilton shales and impure limestones, (8) Tully limestone, (9) Genesee shale, (10) Portage shales and sandstones. (See fig. 1.)

For the purpose of this paper it will not be necessary to speak more fully of any of the formations mentioned above, with the exception of the Hamilton.

Hamilton formation. - The description of the shales and limestones of the Hamilton formation is given in detail in the description of the different zones which make up this formation. In general it may be said that the Marcellus shales immediately above the Onondaga limestone (where they are very black and fine) alternate with eight or ten layers of impure limestone for a distance of 10 feet. The shale becomes harder and a Memoir New York Mus., Vol. II, No. 3, Oct., 1900, pp. 8-9. 


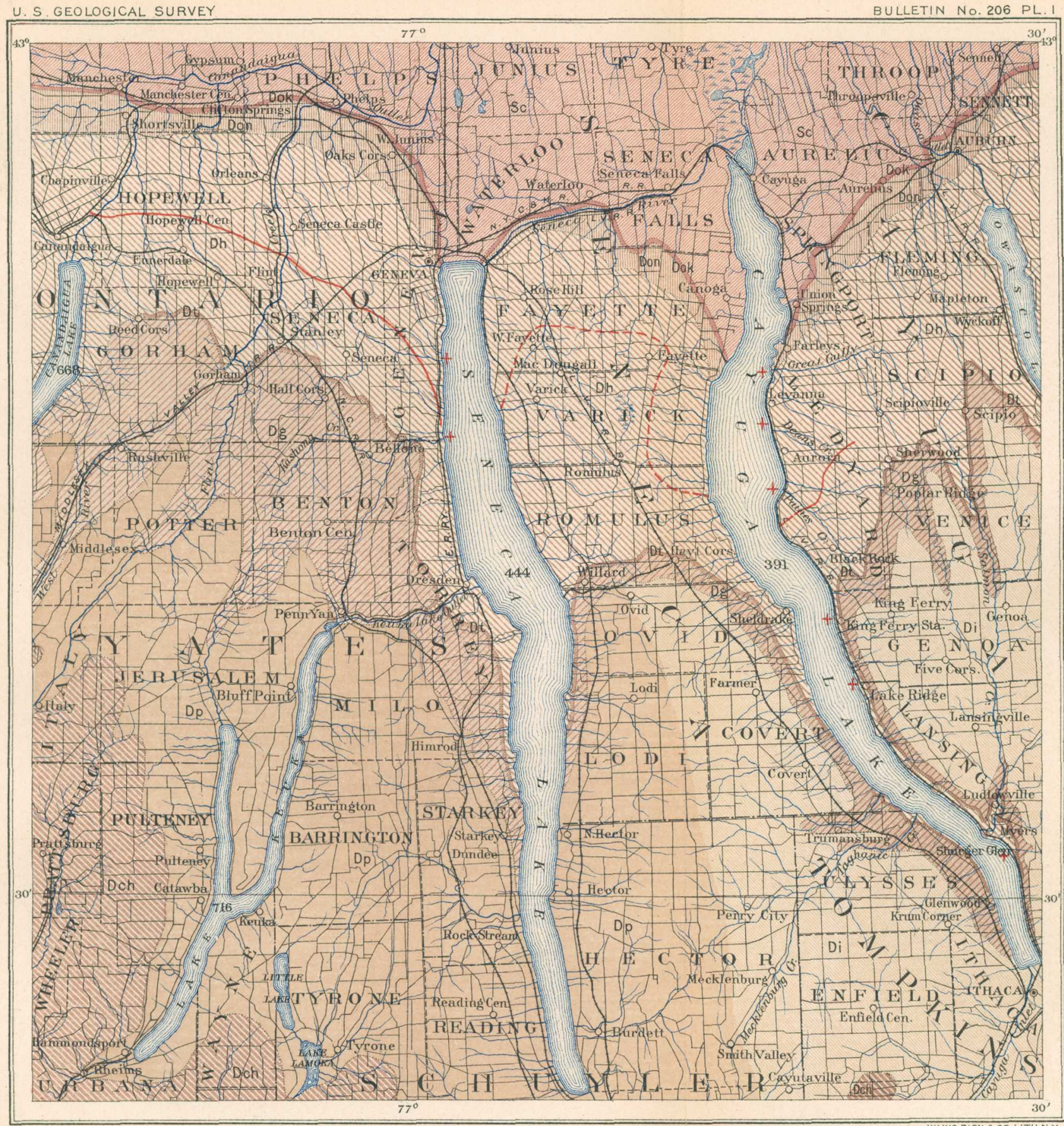

LEGEND

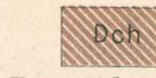
Chemung formation

Dp Di

Portage an Ithaca formation

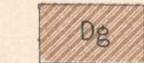

Genesee shale

Dt

Tully limestone

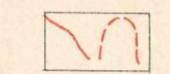

z

Terebratula bed of Hamilton formation basal limestone of Clarke

MUIN

Hamilton formation

Don

Onondaga limestone

Dok

Oriskany sandstone

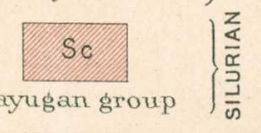

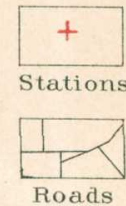

GEOLOGIC MAP OF THE CAYUGA LAKE REGION

Scale 
shown by a recent well boring, is 81 feet thick. Above this limestone are the shales of Zone $\mathrm{C}$, several hundred feet thick, which are very soft, with occasionally a harder, more calcareous, or sandy layer, and several courses of concretions. The thick, impure limestone or hard calcareous shale, Zone D, which overlies the soft shales of Zone C, is very marked because of its hardness and richness in fossils. Immediately above this zone and in contact with it is a layer of shale 50 feet thick, as fine and black in the lower part as the Marcellus shale. Above this the calcareous Hamilton shales continue to the Encrinal, becoming somewhat harder as the Encrinal is approached.

Encrinal bed.-The Encrinal is a crystalline limestone about $1 \frac{1}{2}$ feet thick. Above this the Upper Hamilton or Moscow shales extend to the Tully limestone. The Upper Hamilton shales vary greatly in hardness and faunal combination.

Concretionary layers.-Concretions appear not far from the Encrinal beds. These concretionary layers are at first shaly, but in the Cayuga Lake section become progresssvely more calcareous as the Tully limestone is approached.

The persistence of the concretionary layers was observed for some distance. One course, which contained Leiorhynchus laura and Orbiculoidea lodiensis media (Zone V), was observed at Shurger Glen, Lake Ridge, and King Ferry, a distance of 12 miles. These concretions could not be identified in the Seneca Lake section. . The thin layer of limestone under the Tully, included in Zone $\mathrm{Y}$, was noted at these places also. Both the limestone layers and the fossils of Zone $\mathrm{Y}$ were wanting in the Seneca Lake region. Zone $\mathrm{H}$ at King Ferry, containing small upright concretions, with a characteristic fauna, was found also in Paines Creek, 5 miles north. The extent of the Encrinal beds and hard calcareous shales of Zone D is spoken of in another place (pp. 82-83).

Jointing.-The jointing of the rock in this whole region is exceptionally well developed. The joint planes have a direction of $\mathrm{N} \cdot 20^{\circ}$ $30^{\circ} \mathrm{W}$. and S. $5^{\circ}-15^{\circ} \mathrm{E}$., and are almost vertical. (See Pl. II.) This jointing accounts, in large measure, for the perpendicular faces of the falls and cliffs which are so noticeable in this region.

Tully fold.-As one goes up the lake from Union Springs the general dip of the rock to the south is very noticeable, the different strata continuing for some distance and then disappearing under the lake. Using the Tully as a reference plane, ${ }^{a}$ it was found that from King Ferry to Lake Ridge the strata descend about 45 feet to the mile. To the south the Tully limestone takes a horizontal position and remains a little above lake level for about 3 miles. It there rises into an arch over 6 miles long, with its highest point at least 235 feet above the lake. From this point south the dip is very rapid, varying from a

\footnotetext{
$a$ Dip of rocks in central New York, by S. Q. Williams: Am. Jour. Sci., 3d series, Vol. XXVI,
} 1883, pp. 303-305. 
maximum of 400 feet to the mile, the average being 110 feet. Vanuxem ${ }^{a}$ noticed this fold, and explained it as an apparent but not a real fold, reasoning that since the strata dipped southward the bend of the lake to the east would cut into the strata and give the appearance of a fold. The direction and amount of dip of the strata are such that the bend in the lake could not alone have produced such an arch, although it undoubtedly had some effect. The folds along Seneca Lake and the fault in the outlet of Keuka Lake, which are in a west-of-north direction from the Cayuga Lake arch, point to the explanation that this whole region suffered a lateral pressure sufficient to crumple the strata, thus forming a long fold of which the arch at Cayuga Lake and the undulations in the strata at Seneca Lake are a part. The impure limestone of Zone $\mathrm{D}$ is so folded that the creek cuts throngh it twice before it reaches the fall at Moonshine. In Big Gully Creek the limestone which caps the Marcellus shales is cut through by the stream before it reaches the fall; it also makes a fold to the south, forming falls in two small streams.

The fact that the region is not faulted, that the. folds are easily seen, and that the creeks cut through the glacial drift into the shales, makes the collecting especially easy, and reduces to the minimum the liability to error in locating the horizons in different sections. The difficulties in the way of making accurate measurements with the instruments at hand were such that all measurements given are only approximate. 


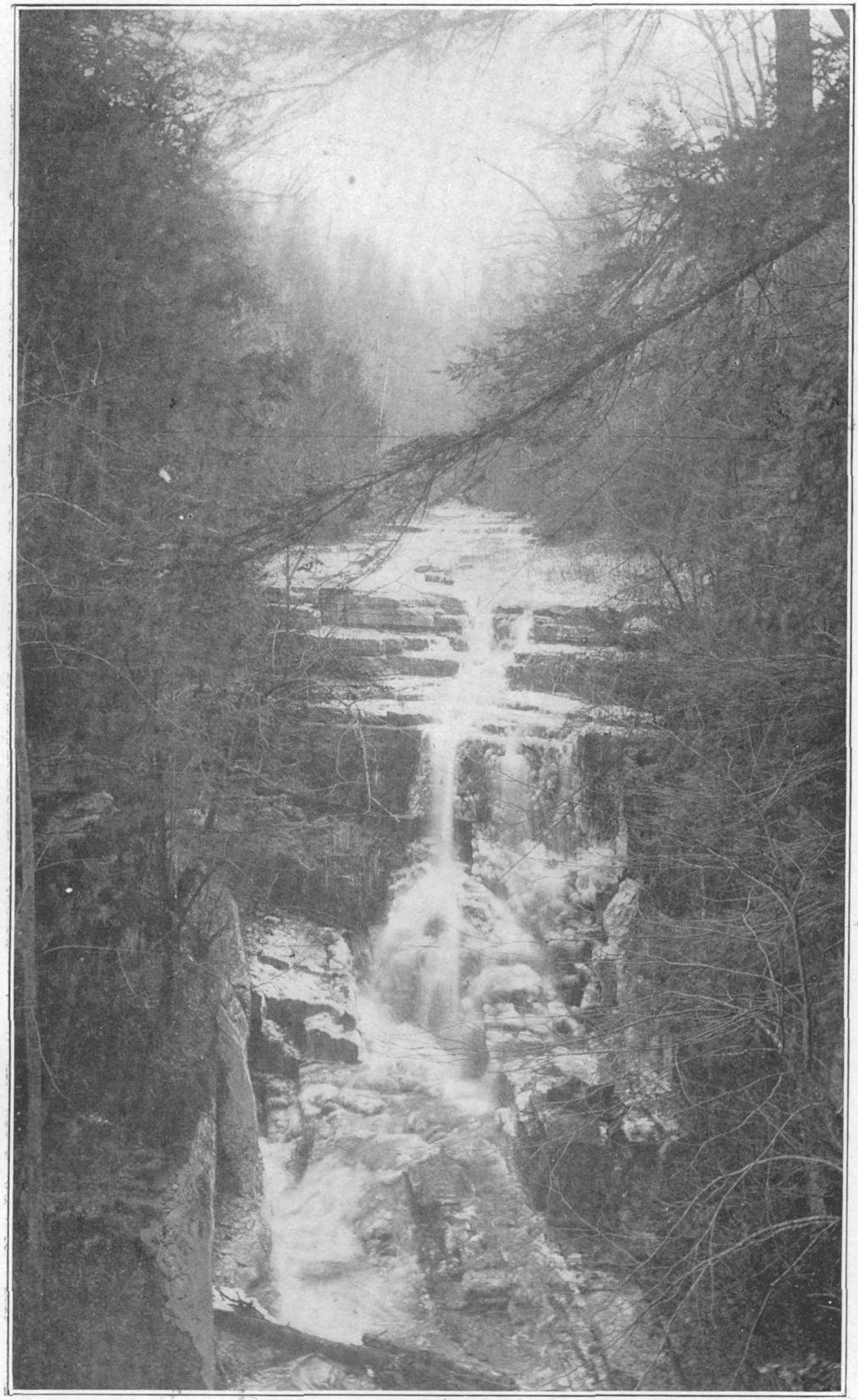

JOINTING IN UPPER HAMILTON SHALE AT SHURGER GLEN.

The stream falls over Tully limestone. 


\section{H A P TER. II. \\ HISTORY OF THE HAMILTON FORMATION.}

McClure.-The first American geologist, William McClure, published a geological map of the United States in the Transactions of the American Philosophical Society in 1809. In this map "he struck out the ground outline of geographical geology." "The line separating the "Primitive rocks" from the "Floetz, or secondary," followed the Oneida and Mohawk rivers of New York to the Hudson River. All the country between the Alleghenies and a line running north and south through the western boundary of Arkansas, with the exception of a narrow strip along the Gulf of Mexico, is marked as Floetz, or secondary, and embraces, in a general way, the formations from the Silurian to the Pleistocene. ${ }^{b}$

Eaton--Amos Eaton after, for that time, considerable travel and observation, published An Index to the Geology of the Northern States in 1820, and later, under the patronage of Stephen Van Rensellaer, made a geological survey of the district adjoining the Erie Canal. These observations he published in $1824 .^{c}$

Werner.-These pioneers in geology were followers of Werner, who attempted to correlate the strata in America with those of Europe as described by the German geologist. As Werner depended entirely upon the lithological character of the strata for his correlations (the value of fossils in correlation not being known at that time) great confusion resulted.

Early attempts at correlation.-Since the Old Red sandstone of England is a conspicuous formation, both McClure and Eaton took it as a convenient reference plane. Eaton first correlated it with the Catskill sandstone (Devonian) and the Triassic sandstone of the Connecticut River. McClure considered the Red sandstone of the Medina group (Silurian) and the Triassic sandstone of the Connecticut River as the equivalent of the Old Red sandstone of Europe. In 1824 Eaton concluded that " the 'Old Red sandstone' rests on the Metalliferous graywacke [Utica and Hudson River group] and underlies the Millstone grit" [Oneida conglomerate of the Medina group]; that is, that the Old Red sandstone (Devonian) should be correlated with a portion of the Medina sandstone, thus placing the greater part of the Upper: Silurian and the Devonian in the Carboniferous.

Search for coal.-After the decision was reached that the Red sandstone of the Medina was equivalent to the Old Red sandstone (Devo-

$a$ Index to the Geology of the Northern States, by Amos Eaton, 1820, p. viii. $b$ Trans. Am. Philos. Soc., Vol. VI, 1809, pp. 411-428.

$c$ Geological and Agricultural Survey of the District adjoining the Erie Canal.

Bull. 206-03-2 
nian) of England which underlies the coal, Eaton expected to find coal in some of the formations in the southern part of the State, and advised the people who lived south of the Medina sandstone to dig for coal wherever there were any indications. Eaton's belief that what we now know to be the Devonian was Carboniferous was strengthened by the finding of thin layers of carbonaceous matter in what, from the localities montioned, must have been the Marcellus and Genesee shales. This coal in very thin layers is occasionally found in these horizons. Because of this advice a great deal of money was wasted in a vain search for coal.

The different formations of the Devonian were not distinguished by Eaton. The "third graywacke" or "pyritiferous rocks" included all the formations above the Onondaga. His description of this "rock" as a calcareous or siliceous gray rock, with aluminous cement, either slaty or in blocks and rich in fossils, and the localities, the end of Cayuga Lake and the south shore of Lake Erie, between its eastern extension and Sturgeon Point, does not distinguish between the different formations. The Hamilton in the Cayuga Lake locality was not included, as is shown by the fact that the Tully was mistaken for the Onondaga (Corniferous) limestone.

Conrad and Hall.-In 1837 Conrad gave as the object of the New York State survey the stratigraphical and economic study of the various rock formations. The attention of his assistants was directed to the "mineral and fossil contents" of the rock, as the fossils." serve to determine with much accuracy the geological age and character of the strata."

In 1838 Hall considered the rocks of western New York as belonging to the Devonian and Carboniferous. His reason for believing this, he says, rested chiefly on the study of the organic remains, especially of the vertical distribution of the trilobite. ${ }^{a}$

Conrad, in the same report, concluded that the rocks of New York, with the exception of the Catskill, terminated with the Upper Ludlow rosks of Murchison [Upper Silurian].

In the section along the Genesee River, given in the same report, the shales between York and Mount Morris are marked as "limestone shales." This was one of the first attempts to separate the rocks above the Onondaga (Corniferous) in New York State into finer divisions.

In the Fourth Annual Report, 1840; Hall compared the fossils from the New York strata with those of England and correlated the Catskill with the Old Red sandstone [Devonian] of England; the Chemung to Moscow shales [Upper Hamilton], inclusive, with the Upper Ludlow rocks [Upper Silurian]; and the Ludlowville [Lower Hamilton] and Marcellus shales with the Lower Ludlow rocks [Upper Silurian], and adopted the name Ludlowville to show this correlation. 


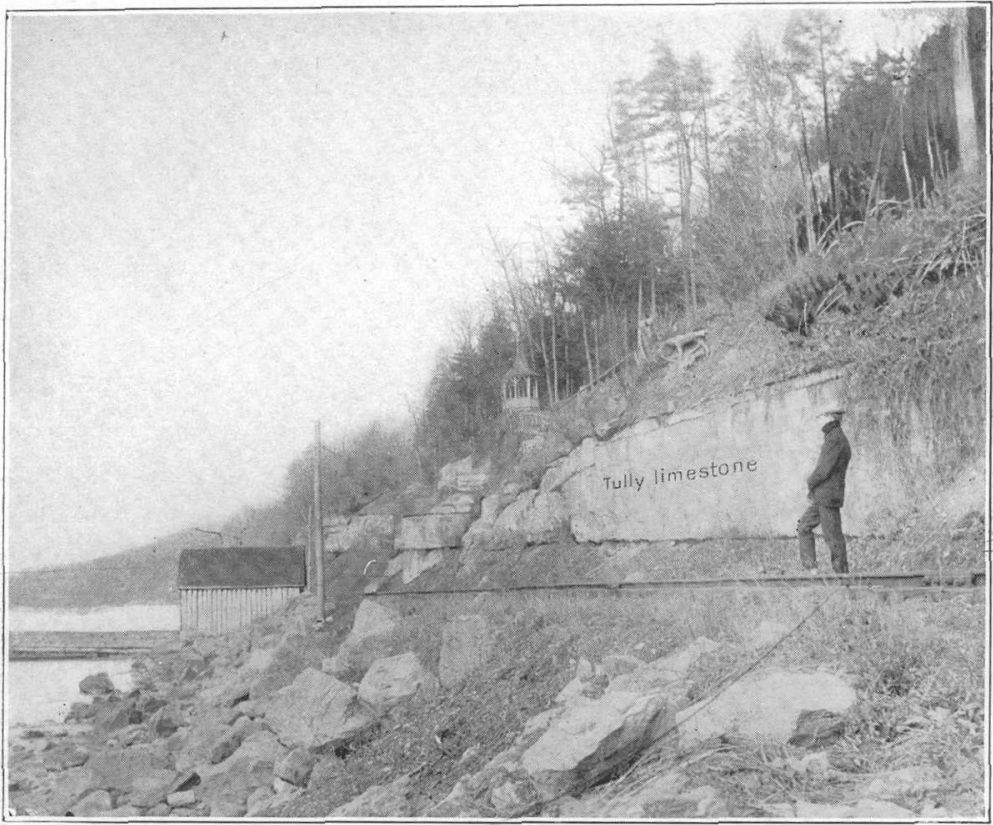

A. Tully limestone, south of shurger glen.

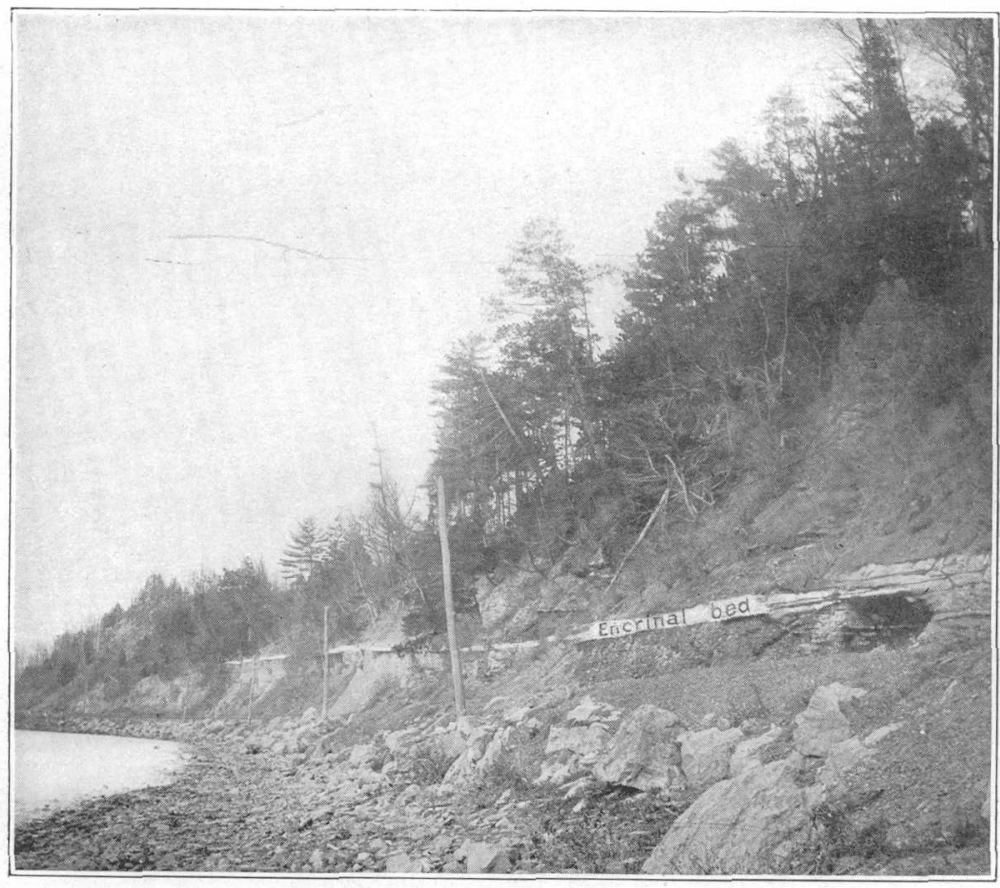

B. ENCRINAL BED, SOUTH OF SHURGER GLEN, SHOWING DIP TO THE SOUTH. 
The report of 1841 placed the Hamilton (called Sherburn group and shales near Apülia) and Marcellus (called Black shale) in the Aymestry [Upper Silurian]. According to this correlation the "Lower Ludlow rock" closed with the Onondaga (Corniferous) limestone.

Verneuil's correlation. - In his concluding remarks on Verneuil's Parallelism of the Paleozoic Deposits of America with those of Europe, ${ }^{a}$ Hall says that the "line of demarcation between the Devonian and Silurian is at the base of the Upper:Helderberg or at the bottom of the Schoharie grit. Verneuil proposed to unite the Marcellus shale, Hamilton shale, Tully limestone, and Genesee shale in one division, and make the Portage and Chemung the second of this period. He correlated the Chemung, Portage, Genesee, Tully, and Hamilton with the formations of Eifel and Devonshire; the Marcellus with the shales of Wissenbach in Nassau.

Renevier's correlation.-In the second edition, 1896, of the Tableau des Terrains Sédimentaires formés pendant des Époques de la Phase Organiqueddu Globe Terrestre, by Professor Renevier, the Marcellus and Hamilton are taken together and considered to have been deposited at the same time as the Tentaculites shales (lower part) of Thuringia and Bohemia, Wissenbacher slates, and the schists "à Phacops Potieri de Bretagne."

Williams's correlation.-The line separating the Meso- and EoDevonian in America was determined by Prof. H. S. Williams to be at the base of the Tully limestone. Previously the Tully had been included in the Meso-Devonian. The reason for this correlation is as follows : ${ }^{b}$

The conclusions we draw from this study of the faunas of the Cuboides zone and the Tully limestone are that within narrow limits, geologically speaking, the point in the European time scale, represented by the beginning of the deposition of the Cuboides Schichten of Aix la Chapelle, etc., is represented in the New York sections by the Tully limestone, and, second, that the representative of the fauna of the Cuboides zone of Europe is seen in New York not only in the Tully limestone, but in the shaly strata for several hundred feet above. Therefore, if we wish to express precise correlation in our classification of American rocks, the line between Middle and Upper Devonian formations should be drawn at the base of the Tully limestone, to correspond with the usage of French, Belgian, German, and Russian geologists, who include Frasnein, Cuboides Schichten, and correlated zones in the Upper Devonian.

The Meso-Devonian must therefore be considered as bounded above by the Tully and below by the Onondaga (Corniferous).

South American Hamilton.-The sandstone of Erere in Brazil, a portion of the Huamampampa sandstone of Bolivia, and a portion of the formations of the Jachel River in central Argentina are correlated with the New York Hamilton. These correlations were determined chiefly by the presence of Vitulina pustulosa and Tropidoleptus carinatus. 


\section{CHAPTER III.}

\section{DESCRIPTIONS OF THE FOSSILIFEROUS ZONES.}

The Hamilton formation, including the Marcellus shales, is in this region, as shown by the Ithaca well section, 1,224 feet thick. ${ }^{a}$.It is bounded above by the Tully and below by the Onondaga (Corniferous) limestone.

The Cayuga Lake section has been divided into twenty-five zones, each zone having been determined by its contained fauna. When, in working up the section, there seemed to be a change in the fauna or the character of the rock, a provisional division was made, the total number of such divisions being seventy-six. Later, in working up the material in the laboratory, it was found necessary to combine many of these divisions, reducing the number to twenty-five.

The name of each zone is the name of the group, genus, or species which seems especially characteristic of the faunule of that zone. The name chosen is not necessarily that of the most abundant species unless that species is, as far as our present knowledge goes, associated with a definite group of fossils. For example, the three Leiorhynchus zones have a faunal resemblance which can not be mistaken, although in the first Leiorhynchus zone Leiorhynchus limitare is the characteristic species, while in the other two zones the species is Leiorhynchus laurc. It is also true, that Leiorhynchus laura may be associated with an abundance of Orbiculoidea lodiensis media, as in Zone V. In the first and second Ambocolia umbonata zones a group of species occurs which is often found associated together when Ambocolia umbonata is abundant. In every zone the fauna is more or less modified by species from lower zones continuing on, and by local conditions, but the essential character of the fauna is determined by the environmental conditions.

A. HAMILTON-ONONDAGA (CORNIFEROUS) ZONE.

Stratigraphy.-This faunule at Cayuga Lake was found in a layer 2 inches thick, almost completely made up of poorly preserved fossils. The shale which held them together was composed of finely comminuted fossils, principally tentaculites. Between this zone and the Onondaga (Corniferous) limestone are eight or ten alternations of impure limestones and fine sooty shale, aggregating 12 feet (see 


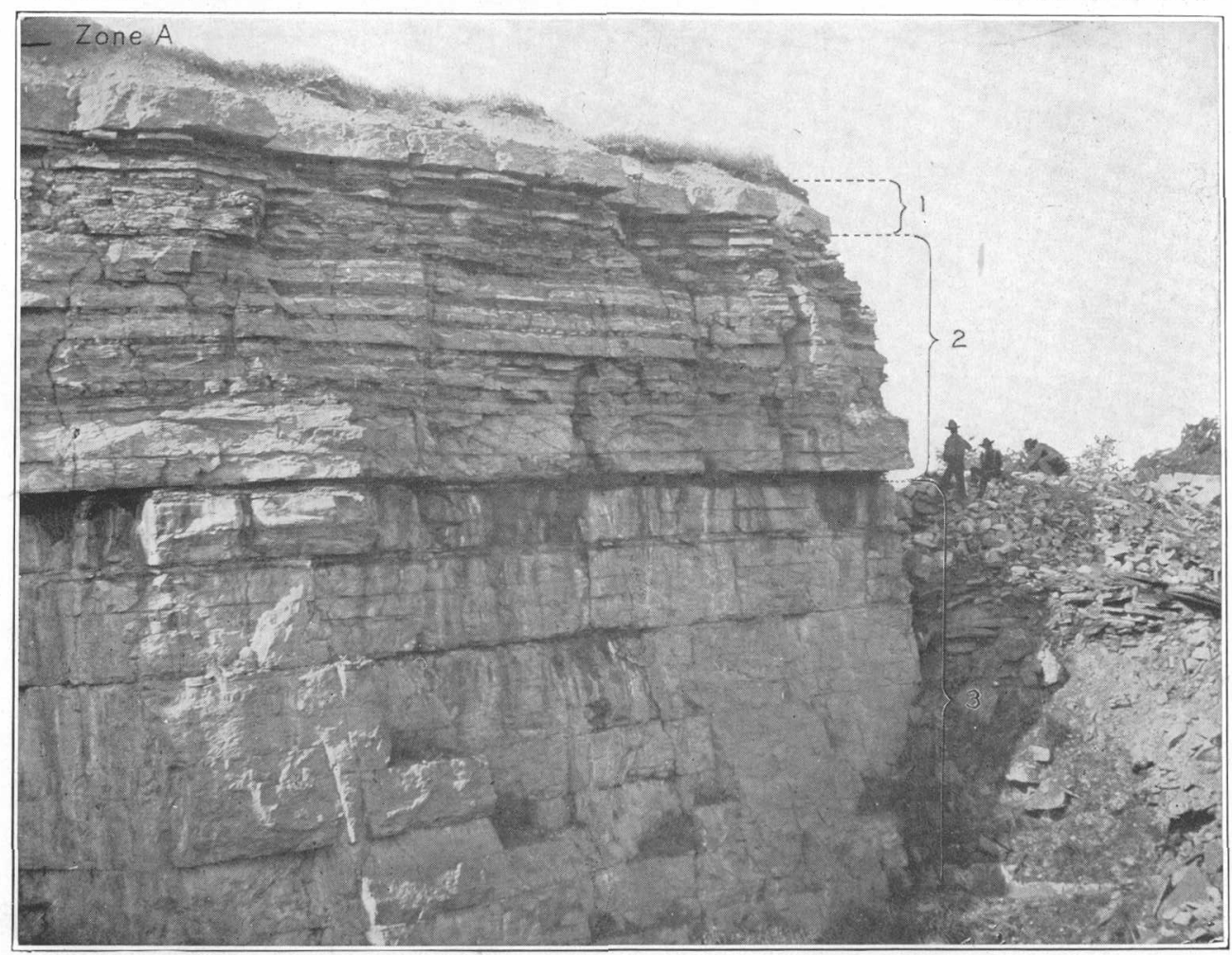

ALTERNATION OF IMPURE LIMESTONES AND SHALES ABOVE THE ONONDAGA BEDS AT UNION SPRINGS. Zone A: 1, Goniatite bed; 2, impure limestones and shales; 3, Onondaga limestone. 
Pl.-IV). - Two feet below this zone is a limestone layer (Goniatite l:mestone), which is purer than any of the layers between it and the

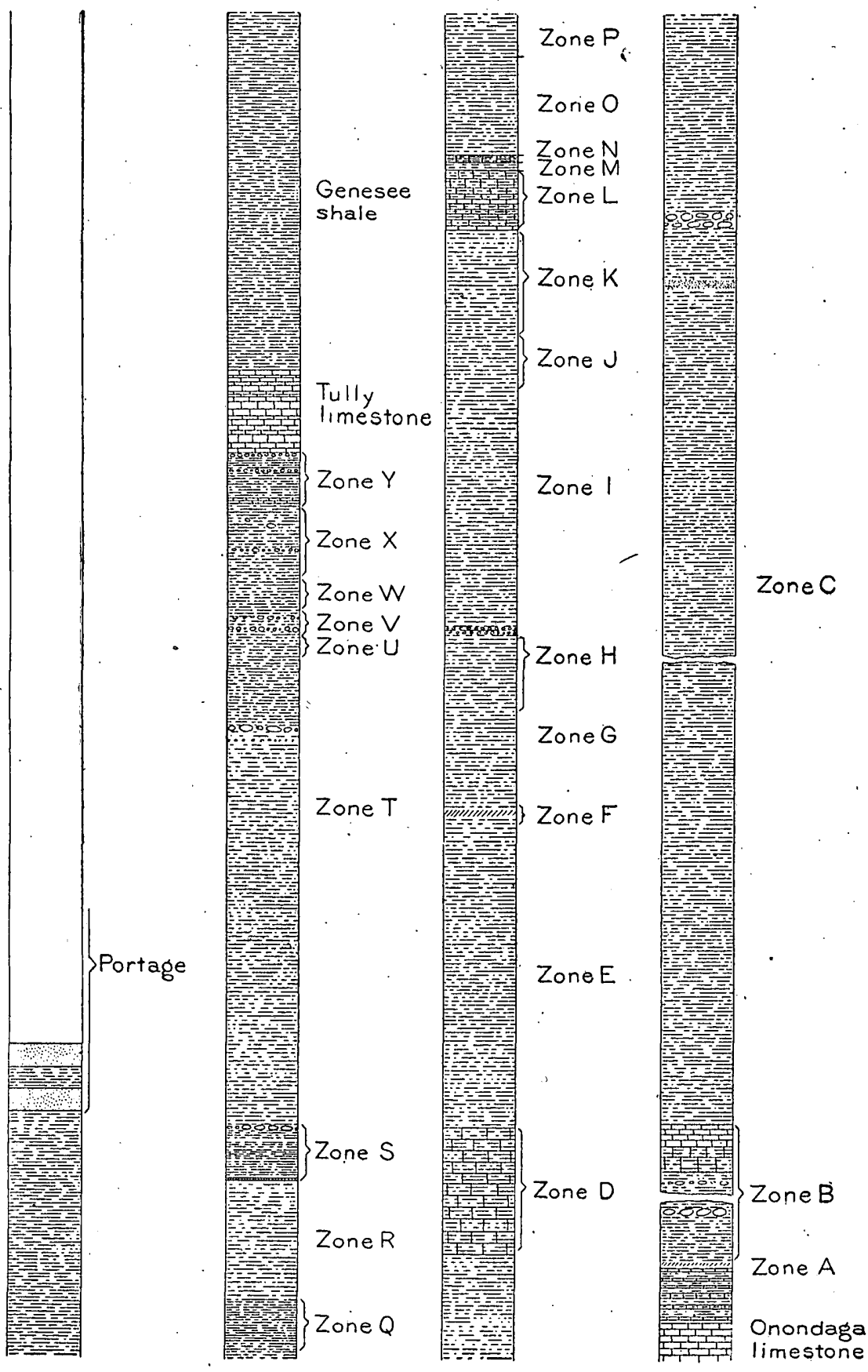

Fig. 2-Zones in Cayuga Lake section.

Onondaga limestone. Below and above Zone $\mathrm{A}$ the shale is very rich in Styliola fissurella and T'entaculttes. 
Faunule.-The faunule of this zone is a mixture of Onondaga and Hamilton species, of which Brachiopoda make up the greater part. It contains Chonetes mucronatus, Ambocœlia umbonata, Tropidoleptus carinatus, and other Hamilton species, together with Spirifer macrus, Anoplotheca camilla, Chonetes lineatus, and Phacops cristata var. pipa of the Onondaga. The absence of Chonetes coronatus and Tropidoleptus carinatus below this level (12 feet above the Onondaga) shows that the Hamilton must have been developed elsewhere for a long period of time before the deposition of this zone. The fauna is remarkable in that it is not a transition between the Onondaga and Marcellus, but between the Onondaga and Hamilton. Although all the species mentioned, with the exception of Chonetes coronatus, have been found in the Marcellus, they are not characteristic of that horizon, but most of them are the common fossils of richly fossiliferous Hamilton zones.

A faunule of similar composition was found in an impure limestone 9 feet above the Onondaga limestone, at Livonia. This faunule contained Anoplotheca camilla associated with Hamilton and Onondaga fossils. ${ }^{a}$

Locality.-South of Union Springs, 12 feet above the Onondaga. Layer of gray shale 2 inches thick.

\section{B. FIRST LEIORHYNCHUS ZONE (Marcellus shale).}

Stratigraphy.-In the first creek south of Great Gully Creek, in the bed of the stream near the mouth, and in the shale along the lake shore south of this, flattened spherical concretions occur, many being 3 feet in horizontal and $i \frac{1}{2}$ feet in vertical diameter. No fossils were found in them.

The Marcellus shale closes with a hard, impure limestone, $4 \frac{1}{2}$ feet thick, which is very noticeable in the creeks in this vicinity, since it forms falls wherever it occurs. It is important in this section, because it makes a distinct line between the shales of the first and second Leiorhynchus zones.

With the exception of 2 feet of bituminous shales immediately above Zone $\mathrm{A}$, the Marcellus shales between Union Springs and Great Gully Creek are covered. It is impossible to make an accurate estimate of the thickness of this zone because of the folding of the strata in this region. At Union Springs the Onondaga is folded, and at Great Gully Creek the limestone layer of the Marcellus is so folded that it forms two falls. This same stratum folds to the sonth, making the rise of ground south of Levanna. The well boring recently made at Ithaca (1900) shows the fine black shale of the Marcellus to be 81 feet thick. It is probable, therefore, that the total thickness is between 80 and 100 feet.

Faunule.-The faunal combination of this zone does not differ materially from that of the second and third Leiorhynchus zones with 
the exception of the replacement of $L$. limitare by $L$. laura. In the lower portion of the zone the shale is extremely fine, and the abundance of Styliola and Tentaculites much greater than in the other Leiorhynchus zones. The shales become coarser and the fossils more abundant (with the exception of Tentaculites and Styliola) as Zone C is approached. The fauna of the upper portion is especially rich in Orthoceratites. About 2 feet below the limestone is a nodular layer extremely rich in Leiorhynchus limitare in an excellent state of preservation. The shale for $2 \frac{1}{2}$ feet below the limestone is very calcareous and coarse, but still contains $L$. limitare and its characteristic fauna.

A Leiorhynchus fauna has approximately the following composition:

Leiorhynchus $\left\{\begin{array}{l}\text { laura, } \\ \text { limitare. }\end{array}\right.$
Chonetes $\left\{\begin{array}{l}\text { mucronatus, } \\ \text { scitulus, } \\ \text { lepidus. }\end{array}\right.$

(Orbiculoidea media).

Strophalosia truncata.

Lunulicardium fragile.
Leiopoteria lævis. Nuculites $\left\{\begin{array}{l}\text { triqueter, } \\ \text { oblongatus. }\end{array}\right.$

Nucula corbuliformis. Styliola fissurella.

Tentaculites.

Phacops rana.

Locality.-Near the mouth of the creeks between Levanna and Farleys. The best exposure for the upper portion is in Great Gully Creek; for the lower, the quarries south of Union Springs.

\section{SECOND LEIORHYNCHUS ZONE.}

Stratigraphy. - This zone is quite uniform in its lithological and faunal characters with the exception of one layer of dark calcareous shale about 15 feet above the Marcellus shale, which contains a greater number of Phacops rana and Ambocolia umbonata than is usual elsewhere in the section. As a rule the shale is fine and seldom contains more than eight or nine species to each 5 feet. Two courses of concretions occur 70 feet below Zone D. Occasionally a harder layer occurs; but, with the exception mentioned, the species do not change with this slight change in sedimentation.' The lower and upper portions of this zone were worked more carefully than the middle portion.

Faunule.-This zone, which is several hundred feet thick, is very poor in fossils. The faunule is one which usually occurs in the fine shales of the Hamilton stage where the conditions were not favorable to a rich Hamilton faunule. The make-up of the fauna is given under Zone $B$. This same faunule is reported from the Livonia section.

Localities.-Paines Creek, south of Aurora, from Moonshine Falls to the lake; Deans Creek, north of Aurora, from Goulds Falls to the lake; Great Gully Creek, south of Union Spring, to the Marcellus shale. It is also finely developed in the Seneca Lake section.

D. FIRST TEREBRATULA ZONE (Basal limestone of Clarke).

Stratigraphy.-Because of its hardness, compared with the soft shales above and below, this zone forms a fall in all of the creeks 
where it appears. Moonshine Falls, on Paines Creek, and the fall in Deans Creek, on the farm of James Gould, are from 30 to 40 feet high. The rock is a hard calcareous shale, almost an impure limestone. The fauna as well as the lithological character separates this zone sharply from the shales above and below. It is 25 feet thick in Paines Creek.

Faunule.-The genera of this section are not, by any means, the most common fossils in this zone; but since they are associated with a peculiar combination of species, both here and at Eighteenmile Creek, the name Terebratula has been used to designate that combination. The combination of species spoken of above is Cryptonella planirostris, C. rectirostris, Meristella haskinsi, Eunella lincklani, Spirifer divaricatus, Vitulina pustulosa, and in the Encrinal, in addition or by substitution, Centronella impressa.

This is the first and only zone in which Heliophyllum halli appeared in any numbers. The locality wàs, however, especially favorable for collecting, on account of the great area of the zone exposed by the folding of the strata and the consequent wearing away of the soft upper shales in several places by the action of the water. One specimen of $H$. confluens was obtained from the Encrinal beds at Black Rock, on Paines Creek, and one specimen of $H$. halli from a doubtful locality in the Upper Hamilton. With these exceptions no specimens of this genus were found above or below Zone D. Vitulina pustulosa is common, and was found in the same abundance in the Encrinal beds, but not elsewhere in the section.

The shale of this zone is extremely fossiliferous. The total number of species found was 84 ; of these, 32 are Pelecypoda, 33 Brachiopoda, 4 Gasteropoda, 3 trilobites, 3 corals.

Localities.-Paines and Deans creeks on the east side of Cayuga Lake; Slate Rock Run on west side of Seneca Lake. D. F. Lincoln ${ }^{a}$ reports it from Bentons Run, west side of Seneca Lake; north of Days Landing; Reeders Creek; West Fayette station; 1 mile west of West Bearytown; 1 mile southeast of Bearytown; Big Hollow Creek east of Romulus. Clarke reports it from Canandaigua Lake and Flint Creek.

NoTE.-This zone is well exposed in Slate Rock Run on the west side of Seneca Lake. In this locality it is 15 feet thick and contains a faunule very similar to that of the Cayuga Lake region. The principal difference noted was the greater abundance of cyathophylloid and Favosite corals. The common fossils of this zone in Slate Rock Run are:

Heliophyllum halli.

Cystophylum americanum.

Favosites.

Chonetes mucronatus.

Eunella lincklæni.

Rhipidomella vanuxemi.

Crinoid stems.

Stropheodonta inæquistriata. 


\section{E. THIRD LEIORHYNCHUS ZONE.}

Faunule.-Immediately above the calcareous shales of Zone D occur 55 or 60 feet of very fine black shales which are extremely barren of fossils. This is especially true of the lower 25 feet, in which but ten species were found, the complete faunule being twenty-seven species. Styliola fissurella and ostracods occur abundantly in thin layers, but in the body of the shale they are seldom seen. With few exceptions the ostracods and styliolæe do not reappear in this section above this zone and never again in abundance.

The change of sedimentation from a firm calcareous to a fine black mud was evidently a condition unfavorable to the rich faunule of Zone D, and either (1) it was replaced by migration of a faunule similar (recurrent) to that of the shales below Zone D or, what seems probable, (2) the species found in Zone $\mathrm{E}$, which were inconspicuous in the faunule of Zone D, lived on while their less adaptable neighbors perished. The shales of this zone contain no brachiopods and only three species of pelecypods-and they are rare-which are not found in Zone $\dot{C}$. They contain one brachiopod and two pelecypods which are not found in Zone D. The faunule of this zone bears a strong resemblance to the "recurrent fauna" of Ontario County."

Localities. - Above and in contact with Zone D in Paines and Deans creeks, on Cayuga Lake, and in the Seneca Take section.

NoTw. - The shales of this zone are of this same character west of Seneca Lake. The resembance to the Marcellus is so strong that Mr. Berlin .H. Wright ${ }^{b}$ called the shales of this zone in the Kashong Creek section "Marcellus." The lithological character and the faunule are both very much like that.of the Marcellus, with the exception of Leiorhynchus limitare, which the writer did not find in the Kashong section.

\section{F. MICHELINIA ZONE (Provisionally).}

Stratigraphy.-This zone is not separated from the lower shales by any distinct line, the division being made by the abundance of the fossils and change in species. It terminates in a more calcareous layer 4 inches thick, in which Michelinia stylopora is common. The number of species is not great except by comparison with the zones above and below. Compared with $\mathrm{E}$ and $\mathrm{G}$ the species are in the ratio (E) $29:(F) 50:(G) 23$. The thickness of the zones, in feet, is in the ratio (E) $55:$ (F) $5:$ (G) 18 .

Faunule.-The only common species are Tropidoleptus carinatus, Nucula corbuliformis, Cypricardella bellistriata, Michelinia stylopora, and crinoid stems. Grammysia constricta, Ceratopora dichotoma, and Michelinia appear for the first time. Tropidoleptus carinatus is very common, but of small size.

Location.-Paines Creek, 60 feet above Moonshine Falls. Five feet thick. 


\section{G. CHONETES VICINUS ZONE.}

Stratigraphy. - This zone comprises the firm shales below the falls nearest the lake, at King Ferry, and the upper portion of the section on Paines Creek; 23 species; 18 feet thick.

Faunule.-Chonetes vicinus, which appeared in Zone F, became very abundant and of large size in this zone. Tropidoleptus carinatus is common. Lunulicardium fragile and Cypricardella bellistriata are found occasionally. The shales are not so barren as the small number of species would indicate, although they are by no means rich in fossils.

\section{Locality.-King Ferry and Paines Creek.}

NotE.-Later investigation shows that the name Chonetes vicinus does not express a faunal combination. The zone is a distinct one at King Ferry, but is an expression of peculiar local conditions rather than a normal faunule. This zone was not found in the Kashong Creek section.

\section{H. TRANSITION ZONE.}

This zone does not have a distinctive faunule and is probably a transition between Zones $\mathrm{G}$ and $\mathrm{I}$.

Locality.-King Ferry, N. Y.

\section{FIRST CYPRICARDELLA BELLISTRIATA-ATHYRIS SPIRIFEROIDES ZONE.}

Faunule.-The abundance of Cypricardella bellistriata, Athyris spiriferoides, and Spirifer pennatus is characteristic of this faunule. The relative abundance of all of the species in the zone changes somewhat from the bottom to the top. Tropidoleptus is common in the lower third, rare in the middle, and common again in the upper third. Pholidostrophia iowaensis appears for the first time in the lower third and was not common elsewhere in the section.

Location.-King Ferry, above the first falls; 47 feet thick.

NotE.-The faunule of the shale 25 feet below the Encrinal beds, 19 feet thick in the Kashong Creek (Seneca Lake) section, bears a stronger resemblance to Zones $\mathrm{I}$ and $\mathrm{K}$ than to $\mathrm{J}$, but the faunule as a whole has a different facies. It resembles $I$ in the abundance of Tropidoleptus carinatus CA, Chonetes mucronatus CA (instead of C. vicinus), and Spirifer pennatus. It differs in the scarcity of Cypricardella bellistriata and A. spiriferoides and in the abundance of Bryozoa and crinoid stems. The 25 feet of shale immediately underlying the Encrinal is very poor in fossils, the faunal combination of which is not plain.

\section{J. TELLINOPSIS ZONE.}

Faunule.-This faunule differs from that of Zones $\mathrm{K}$ and $\mathrm{I}$ in its paucity of spirifers, Athyris spiriferoides and Tropidoleptus carinatus 
and in the abundance of Ambocolia umbonata, Tellinopsis subemarginata, and Modiomorpha. There is one thin layer of Ambocolia umbonata and Chonetes scitulus. The shale of Zone $\mathrm{J}$ is finer than that of Zone $K$ and more fossiliferous.

Locality.-King Ferry, 20 feet below the Encrinal beds; 10 feet thick.

\section{K. SECOND CYPRICARDELLA BELLISTRIATA-ATHYRIS SPIRIFER-} OIDES ZONE.

Faunule.-This faunule is a recurrence of Zone I, with slight modifications. The numerous individuals of the upper third of Zone $J$ are the characteristic fossils of $\mathrm{K}$ with the exception of Chonetes vicinus. Other species of Chonetes are common and balance the loss of C. vicinus. The abundant species of Zone $\mathrm{I}$ are most common in Zone $\mathrm{K}$. This zone resembles Zone $\mathrm{X}$ of the Upper Hamilton, except that in Zone $\mathrm{X}$ Leiorhynchus laura continues from Zone V.

Locality.-King Ferry, extending down from the Encrinal for 22 feet.

\section{SECOND TEREBRATULA ŻONE (ENCRINAL BEDS). $a$}

Stratigraphy. - The Encrinal bed includes 8 feet of calcareous shales, impure limestone, and $1 \frac{1}{2}$ feet of crystalline limestone, with an abundance of crinoid stems in the upper part.

Faunule.-Of the 47 species occurring in this bed, 14 are from the crystalline limestone. No fossils are abundant. Of the 7 species which are common 3 are distinctive; Vitulina pustulosa is found also in D; Centronella impressa occurs here for the first time and does not appear again; Eunella linckloni is found also in D and $\mathrm{Y}$; Spirifer divaricatus, one fragment, is found in D; Nucleospira concinna is rarely found in the section, and Spirifer granulosus reappears here. (For discussion of Encrinal see Chapter V.)

Locality.-This zone, called also the Encrinal bed, includes the crystalline Encrinal beds and impure limestone and shales, 8 feet in all, found in the creeks between Shurger Glen and Aurora.

\section{ORTHONOTA ZONE.}

Faunule.-This zone differs decidedly from that above and below in the composition of its fauna. A glance at the accompanying table (PI.V) will show the distinctness of this zone. The common Pelecypoda are Phthonia nodicostata, Orthonota undulata, Prothyris lanceolata, and Tellinopsis subemarginata.

Locality.-Shurger Glen. A rather fine shale $1 \frac{1}{2}$ feet thick underlying a harder layer (Zone $\mathrm{N}$ ) which forms a small falls $2 \frac{1}{2}$ feet high a short distance from the fall over the Encrinal.

a Including the genera of Section A; cf. Schuchert: Bull. U. S. Geol. Survey No. 87, p. 124. 


\section{N. (TRANSITION ZONE.)}

Zone $\mathrm{N}$ is a rather hard, limy layer, 6 inches thick, which forms the capping for a falls $2 \frac{1}{2}$ feet high. The faunule is not a distinct one. The abundance of Tropidoleptus carinatus places it with the zone which follows, while the fewness of Chonetes and abundance of crinoid stems and Bryozoa places it with the preceding faunule. It is lithologically distinct, but must be called a transition faunule.

\section{O. CHONETES ZONE.}

Faunule.-The abundance of Chonetes mucronatus and $C$. scitulus is very noticeable. In a fine shale, 3 inches thick, is an abundance of Spirifer pennatus and Tropidoleptus carinatus. A hard, argillaceous, sandy layer above this is very rich in S. pennatus. This zone is not well marked, and is probably very local.

Locality.-Shurger Glen. Coarse and rather sandy strata overlying the hard layer forming the small fall; 10 feet thick.

\section{P. FIRST AMBOCGELIA ZONE.}

Faunule.-There is little difference between this zone and Zone $\mathbf{R}$ except that there is a greater abundance of individuals in the latter. Ambocolia umbonata and Phacops rana are abundant and Pholidops hamiltonice and Chonetes mucronatus are common. Pelecypods, with the exception of Palceoneito constricta, are rare. The association of $P$. rana and $A$. umbonata is seen.in thin layers throughout the section. (See under A. umbonata, Chapter IV.)

Locality. - Twenty feet above the Encrinal beds at Shurger Glen; 5 feet thick.

Q. CHONETES LEPIDUS ZONE (rather barren shales).

Faunule.-The 15 feet of thin shale of which this zone is composed is very barren both in individuals and in species, the upper 5 feet being extremely so. Only 16 species were found in the entire bed; of these 6 species are found in the upper 5 feet and 12 species in the lower 10 feet. In the upper 5 feet Chonetes lepidus and $A$. umbonata are the only common fossils.

The conditions in this region during the deposition of these shales were very unfavorable to life. At first the fauna was rather large, but at last the two species mentioned above were almost the only ones that were able to survive. The conditions were not unlike those which existed during the deposition of the muds forming Zone $\mathrm{E}$. The effect of the unfavorable environment is seen in the small size and number . of individuals.

Locality.-Shurger Glen. Twenty-five feet above the Encrinal beds and 20 feet below the concretionary layer of Zone S. 


\section{R. SECOND AMBOCCELIA ZONE.}

Stratigraphy.-This zone is bounded above by the StropheodontaCoralline zone and below by fine shale. It is a very marked zone in the Shirger Glen section. Large blocks of shale which have fallen from the cliff are almost completely made up of Amboccelia umbonata, with many Phacops rana in an excellent state of preservation.

Faunule.-Besides A. umbonata and P. rana, Pholidops hamiltonice and Palceoneilo constricta are very common. Chonetes mucronatus is often found. A comparison of "the fauna of the Spirifer consobrinus fauna, Da" of Grabau " with this zone shows that (1) the relative position and (2) the faunule are the same. (See under Ambocuetica umbonata.)

Locality.-Shurger Glen and King Ferry, 40 feet above the Encrinal beds. Underlies the concretionary layer of Zone S. Twenty-five feet thick.

Note. - A bed with a fauna of this same composition occurs in the Kashong section. The resemblance is so striking that it can not be mistaken. It is about 80 feet above the Encrinal beds in this section and but 40 feet at Shurger Glen. The zones of the two sections may be continuations of the same bed, but there is no evidence to that effect except the character of the faunule and the rock.

\section{S. STROPHEODONTA-CORALLINE ZONE.}

Stratigraphy.-This zone includes the lowest concretionary layer in which the concretions are of large size. The concretions are shaly, but the shale in which they are embedded is rather more calcareous than usuàl. The fossils occur in three or four layers, about 2 or 3 inches thick. In these thin fossiliferous layers the shale weathers into a mud, leaving the fossils conspicuous. In the lower part of the zone occurs a very thin layer composed almost entirely of crinoid joints.

Faunule.-The rarity of Ambocolia umbonata and the abundance of Bryozoa and crinoids, together with Stropheodonta incequistriata, S. concava, Rhipidomella vanuxemi, and corals in considerable numbers, make this zone distinct from that above and below.

Locality.-Shurger Glen, 60 feet above the Encrinal beds. In a eoncretionary layer 10 feet thick.

NOTE.-Thin layers containing this faunule commence 40 feet below the Tully at Kashong Creek (Seneca Lake), and occur frequently for 30 feet. The common fossils are:

Spirifer pennatus.

Stropheodonta inæquistriata.

Stropheodonta concava.

Sitropheodonta junia.
Atrypa reticularis.

Ștreptelasma rectum.

Amplexus sp.?

Crinoid stems.

This faunule responded very quickly to certain conditions, as is shown by its frequent occurrence in the Seneca and Cayuga lake sections. It also has a very constant faunal combination. 


\section{T. MODIELLA PYGMAAA ZONE.}

Stratigraphy.-The shale in this zone is compact and fairly uniform throughout. It is not very fossiliferous, but by no means barren, except where thin layers of fine shale occur.

Faunule.-This is distinctly a pelecypod zone in which small pelecypods, such as Nucula, Modiella, Palcooneilo, and Tellinopsis are common. Leiopteria is frequently found near the center of the zone. The total number of species in the zone is large because of the occasional appearance of a number of rare species. The number of species of brachiopods are to those of pelecypods as 27 to 39 . Of the brachiopods, Spirifer pennatus and Amboccelia umbonata are found in all parts of the zone, sometimes being very common. Stropheodonta, Nucleospira, and Reticularia are absent. Nucula, Nuculites, Modiella, and Palceoneilo, which are rare in the lower zones, become common in this zone, though never abundant. The faunule disappears with the appearance of Leiorhynchus laura and Orbiculoidea.

Locality.-Shurger Glen, 40 feet below the Tully limestone. A Septaria layer is embedded in the upper few feet of this zone. The total thickness is 98 feet.

\section{U. AMBOCCELIA PR EEUMBONA ZONE.}

Faunile.-This is a transition zone between $\mathrm{T}$ and $\mathrm{V}$. It is characterized by the commonness of $A$. prceumbona, which appeared a foot below this for the first time in this section, and in the reappearance of Spirifer tullius, which, until within a foot of this zone, was not present in the shale below for 20 feet. The faunal combination is not plain.

Locality.-Shurger Glen. Underlies the concretionary layer of Zone V. Five feet thick.

NotE.-A bed in the Kashong (Seneca Lake) section contains the following species:

Ambocolia præumbona.

Leiorhynchus laura.

Orbiculoidea lodiensis media.?

Chonetes mucronatus.

This faunule is probably a continuation of that at Cayuga Lake.

\section{ORBICULOIDEA OR MODIFIED LEIORHYNCHUS ZONE.}

Leiorhynchus laura and Orbiculoidea lodiensis media in abundance in a fine shale make this a very distinct zone. It may be considered a Leiorhynchus zone with Orbiculoidea lodiensis media, modified by the addition of S. tullius and Ambocœlia prceumbona. In the center of the zone, however, the faunule is, with the addition of O.loriensis media, an almost typical Leiorhynchus fauna. T'he Leiorhynchus laura and Orbiculoidea lodiensis media are very large and in an excellent state of 
preservation in the concretionary layer, which is embedded in the fine shale of this zone. These concretions are over a foot in horizontal diameter.

Locality.-Shurger Glen, Salmon River, Lake Ridge, King Ferry, 30 feet below the Tully limestone.

\section{W. (TRANSITION ZONE.)}

Faunule.-The abundance of Rhipidomella vanuxemi and Phacops rana, which are rare in the next zone above, and the frequency with which Pholidops hamiltonice and Dalmanites boothi occur, present the appearance of a somewhat distinct faunule. However, Chonetes mucronatus, Leiorhynchus laura, Spirifer audaculus, Stropheodonta junia, and S. perplana are common to both.

The faunule can not be taken as a part of either Zone $\mathrm{V}^{\circ}$ or Zone $\mathrm{X}$, although it contains a number of species of each, nor can it be considered a separate zone. During its deposition the conditions permitted the migration of a Spirifer-Atrypa faunule, together with $R$. vanuxemi and $P$. rana, and at the same time were not unfavorable to some of the species of the Orbiculoidea faunule.

Locality.-Shurger Glen. In a pyritiferous concretionary layer, 23 feet below the Tully, 10 feet thick.

\section{SPIRIFER-ATRYPA ZONE.}

Faunule.-Atrypa reticuiaris, Athyris spiriferoides, and Spirifer - audaculus occur here in very great abundance. S. granulosus has a greater development than in any other portion of the section. Leiorhynchus laura is less abundant than in the zone below and is not found in the Cystodictya zone. Bryozoa, which were rare in Zone W, begin to be abundant and continue in great numbers to the Tully limestone.

Locality-Shurger Glen. Nine feet below the Tully limestone.

\section{Y. CYSTODICTYA ZONE.}

Stratigraphy.-The Hamilton stage closes with this zone, which includes an alternation of limestone and limy shales and a nodular layer. This condition is seen at Ludlowville, Lake Ridge, and King Ferry.

Faunule.-The zone is rich in Bryozoa, especially Cystodictya incisurata, and crinoid stems. Tropidoleptus carinatus is the fossil most often seen in the upper portion. Spirifer pennatus and $S$. audaculus are very common, while $S$. marcyi is represented by wellpreserved specimens in the calcareous shales 5 feet below the Tully limestone. Pelecypods are very rare in the upper few feet. This, with a slight modification, is the same as the Cystodictya faunule of Grabau, which at Eighteenmile Creek occurs in the Lower Hamilton. 
Locality.-Shurger: Glen, Salmon Creek, Lake Ridge. In contact with the Tully limestone.

NOTE.-The Hamilton formation in the Kashong Creek section, Seneca Lake, closes with a fine shale 7 feet thick, very much like the Genesee in appearance and very poor in fossils.

The faunule of this zone is:

Ambocœlia umbonata.

Pholidops hamiltoniæ.

Phacops rana.

Tropidoleptus carinatus.
Ostrocods.

Palæoneilo constricta.

Tèllinopsis subemarginata.

\section{EXPLANATION OF DIAGRAMS, PL. V.}

Diagram.A.-With the exception of Zone A, 2 inches thick, 12 feet above the Onondaga (Corniferous) limestone, which is very rich in individuals, the number of species of Pelecypoda and Brachiopoda is very uniform throughout the soft shales until Zone $\mathrm{D}$ is reached. A few feet of the Upper Marcellus shales are quite fossiliferous, but the number of species is not large. The concretionary layer of Zone $\mathrm{C}$ contains a faunule fairly rich in individuals, but poor in species.

As indicated by the angle, Zone D is sharply defined from the shales above and below by the great abundance of species and individuals as well as by the greater hardness of the rock. With the exception of a portion of Zone $X$, the lower 10 feet of Zone D contains more species of both Brachiopoda and Pelecypoda than the same number of feet in any other part of the section. In the lower portion of the zone the brachiopods and pelecypods are represented by an equal number of species. In the upper portion both decrease in the number of their species, but the lamellibranchs suffer the greater loss.

The most barren shales of the section above Zone D, both in individuals and in species, are the 5 feet of fine black shales immediately in contact with it. The black shales. of this zone (E) are very noticeable.

Zone $\mathrm{F}$, which is a coralline zone, is rich in species, especially of pelecypods. After reaching a low point in Zone $G$ there is a rapid increase in pelecypods, the increase in brachiopods remaining almost uniform thronghout Zone I, while the pelecypods reach a high point in the center of the zone, but fall below the Brachiopoda toward the upper portion.

The next noticeable change is in the Encrinal bed, Zone L, where the pelecypods are extremely rare, while the brachiopods have a rich development. The brachiopods gradually decrease in the number of species until Zone $\mathrm{Q}$ is reached, where there is a greater paucity than in any other zone in the Upper Hamilton. The pelecypods become common in Zones $\mathrm{O}, \mathrm{M}$, and $\mathrm{N}$, but become rare in species in Zone $\mathrm{Q}$. In the 35 feet above Zone $Q$ there is an increase, which culminates in Zone S, the brachiopods being predominant. Above Zone S to Zone 

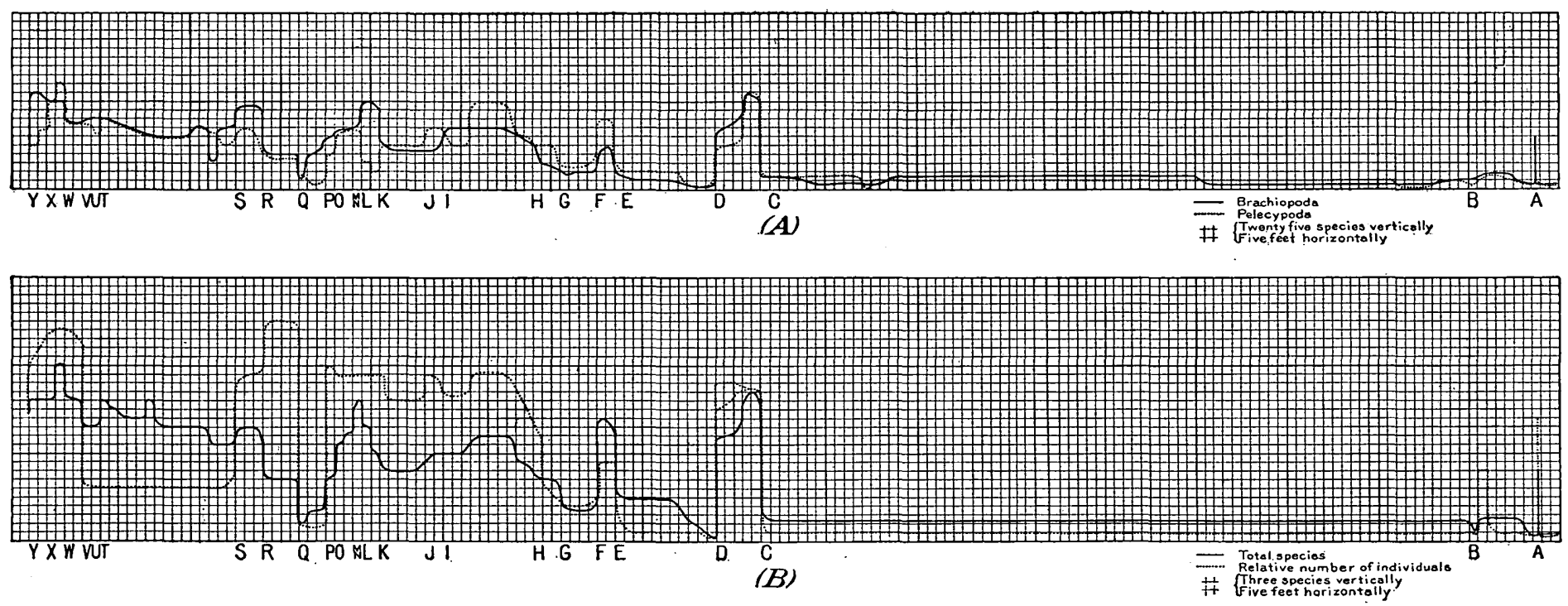

A. DIAGRaM SHOWING RELATIVE ABUNDANCE OF PELECYPODA AND BRACHIOPODA IN THE CAYUGa LAKE SECTION. B. DIAGRAM SHOWING RELATIVE ABUNDANCE OF INDIVIDUALS AND SPECIES IN THE CAYUGA LAKE SECTION. 
$\mathrm{X}$, with one local exception, the number, both of pelecypods and of brachiopods, is quite uniform. In Zone $\mathrm{X}$ the pelecypods reach their greatest development in the section, the brachiopods also being well toward their highest point.

The impure limestones of the upper few feet, with which the Hamilton formation closed, seemed unfavorable for pelecypods, as was the case in the Encrinal beds, and very favorable for brachiopods. From Zone $\mathrm{X}$ the pelecypods decrease and the brachiopods increase to the contact with the Tully limestone.

Diagram B.-The abundance of individuals is represented only approximately, as there is no practical method of determining accurately the actual number of individuals to each 5 feet.

In the fine shales of the Marcellus are thin layers full of Styliola and Tentaculites (these are not represented in the diagram). Above Zone A, which is very rich in individuals, the shale is almost barren as far up as it was exposed at this station (Union Springs), with the exception of Tentaculites and Styliola. For a few feet below the limestone with which the Marcellus closes there is an abundance of individuals of Leiorhynchus limitare and of Orthoceratites. The shales above this limestone, Zone $\mathrm{C}$, are almost barren in many places, but now and then a fossil is found. Occasionally a thin layer of fine shale a fraction of an inch thick contains Leiorhynchus laura or Strophalosia truncata in great numbers.

In Zone D the impure limestone which forms the capping of Moonshine Falls seemed richer in individuals than the lower shales of this zone. This may, however, have been due to the more favorable collecting because of the weathering out of the fossils. Above Zone D are a few feet of almost completely barren shales, Zone E; above these shales the remaining 30 feet of Zone $\mathbf{E}$ continues poor in individuals and species to Zone $F$. In Zone $F$ there is a sudden increase in the number of species and individuals, which makes it a quite distinct zone. The number of individuals, however, did not increase in the same ratio as the species. From Zone $G$ to the middle of Zone I there is a rather gradual increase in species and individuals. From this point the number of species decrease to the Encrinal beds, while the number of individuals vary. The species become abundant in the upper part of the Encrinal bed and decrease to Zone Q, in which the shale is more barren, in species and individuals, than in any other zone in the Upper Hamilton.

The great abundance of individuals of the Zones $P$ and $R$ is shown. Zone $\mathbf{R}$ is, according to the diagram, the most fossiliferous zone (in individuals) in the section, although the number of species is by no means large.

From Zone $\mathrm{S}$ to Zone $\mathrm{W}$ there is a rather regular increase in the number of species, while the number of individuals is rather small. Zone $\mathrm{S}$ is rich in number of species as well as in abundance of indi-

Bull. 206-03-3 
viduals. Zone $\mathrm{V}$, the Orbiculoidea zone, is separated from the other zones not only by its faunal combination, but in the fewness of its species; the number of individuals is not greatly different from that of the shale below. Zone $X$ is the richest in species of any zone in the section. The abundance of individuals is great in proportion. Zone $\mathrm{X}$ was worked more thoroughly than any other except Zone $\mathrm{Y}-$ a fact which will in a measure account for the large numbers of species and individuals in the collection. From this zone to the Tully limestone the total number of species becomes less. 


\section{CHAPTER IV.}

ANNOTATED LIST AND CLAS:IFICATION OF SPECIES FOUND IN THE HAMILTON FORMATION OF THE CAYUGA LAKE SECTION.

\section{Subkingdom COELENTERATA. Class ANTHOZOA-ACTINOZOA.}

The members of this class are, with a few exceptions, rare in the Cayuga Lake section. They are, however, of considerable importance since, when they are common, they are associated with a peculiar combination of species.

\section{Subclass TETRACORALLA Haeckel.}

Family ZAPHRENTID Æ E. \& H.

Genus STREPTHLASMA Hall.

1. Streptelasma rectum Hall.

Ill. Dev. Fos. Hall, 1876, pl. 19.

This is the commonest of the corals at Cayuga Lake. It is chiefly confined to the upper 150 feet of the section. When it occurs with stropheodonta it has a definite faunule.

\section{Genus ZAPHREN'TIS Rafinesque.}

2. Zaphrentis simplex Hall.

Ill. Dev. Fos. Hall, 1876, pl. 21.

Four specimens of this species were found in the Cystodictya zone (Y).

Genus AMPLEXUS Sowerby.

3. Amplexus sp. undet.

ח1. Dev. Fos. Hall, 1876, pl. 3.

Next to Streptelasma in abundance is a species of Amplexus, found principally in the Modiella zone ('T). It differs from the figures of A. hamiltonice and $A$. intermedius. The coral is very much flexed and has a jointed appearance, the constrictions sometimes being very warked. 


\section{Family CYATHOPHYLLID AE E. \& H.}

\section{Genus HELIOPHYLLUM Hall.}

4. Heliophyllum halli E. \& H.

Ill. Dev. Fos. Hall, 1876, pl. 23.

This species is restricted to Zone $\mathrm{D}$, with the exception of a single specimen from a doubtful locality in the Upper Hamilton. A number of specimens were obtained, two of the largest of which measured 220 and $270 \mathrm{~mm}$. in length and $65 \mathrm{~mm}$. in diameter. $H$. halli is very common in the "Basal limestone" of Ontario County, and is confined to a narrow zone within a few feet of the Encrinal beds in the Eighteenmile Creek section.

This species is very common in the "Basal limestone" of the Seneca Lake section.

\section{Heliophyllum confluens Hall.}

IIl. Dev. Fos. Hall, 1876, pl. 26.

A single specimen was found in this section-in the Encrinal beds of Paines Creek. At Eighteenmile Creek H. confluens is also restricted to the Encrinal beds.

\section{Genus DIPHYPHYIIUM I,onsdale.}

6. Diphyphyllum archiaci Billings.

Geol. Sur. Mich., vol. 3, 1873-1876, p. 126, pl. 47.

This species was found in Zone Y. A cross section showed the characteristic arrangement of the septa.

\section{Subclass HEXACORALLA Haeckel. \\ Suborder TABULATA E. \& H. \\ Family FAVOSITID AE E. \& H. \\ Genus FAVOSITHES Lamarck. \\ 7. Favosites argus Hall.}

IIl. Dev. Fos. Hall, 1876, pl. 13.

One specimen from Zone $\mathrm{Y}$ is probably of this species. . It is of very much the shape of fig. 2, pl. 13, of the "Devonian Fossils." The arrangement of the large and small cells can not be made out.

8. Favosites sp. undet.

Favosite corals from several zones were too imperfectly preserved for specific identification. They did not show any of the specific characters of $F$. argus. 
Genus MICAXEINIA de Koninck.

9. Michelinia stylopora Eaton.

Ill. Dev. Fos. Hall, 1876, pl. 18.

This species is common in Zone $\mathrm{F}$, but nowhere else in the section. At Eighteenmile Creek it is restricted to a few feet at the base of the Lower Hamilton. At Kashong Creek very large specimens of this species occur in a narrow bed 13 feet above the "upper fall" (above Encrinal). A few specimens were also found in the "Basal lime-" stone" of Slate Rock Run.

\section{Genus rTRACHÝPORA F. \&H.}

10. Trachypora (Dendropora) ornata Rominger.

Geol. Sur. Mich., vol. 3, 1873-1876. p. 62, pls. 23-24.

A few well-marked fragments of this species were found in the Cystodictya zone (Y), and in the Encrinal band. This species is not uncommon in the shales forming the falls below the Encrinal in the Kashong Creek section.

\section{Family AULOPORID $\mathbb{E}$ Nicholson.}

\section{Genus AULOPORA Goldfuss.}

11. Aulopora serpens Goldfuss.

Geol: Sur. Mich., 1873-1876, p. 81, pl. 33.

Two very imperfect fragments of this species were found.

Genus CERATOPORA Grabau.

12. Ceratopora dichotoma Grabau.

Proc. Bos. Soc. Nat. His., vol. 23, 1899, p. 418, pl. 4.

This species, with well-marked characters, was found in Zones $\mathrm{F}$ and O. Excellent specimens also occur above the Encrinal at Kashong Creek.

\section{Family SYRINGOPORID $\not E$ E. \& H.}

Genus SYRINGOPORÀ Goldfuss.

13. Syringopora sp. undet.

Geol. Sur. Mich., vol. 3, 1873-1876, p. 79.

A colony of this genus 10 or 12 feet long and. 5 to 8 inches in thickness occurs in the lower part of Zone $D$. The specific characters are not distinct enough to warrant a specific identification. The "Basal limestone" of the Slate Rock Run (Seneca Lake) contains many colonies of this coral. 


\section{Family CH ATETID $A$ E. \& H. \\ Genus CH ANTEYTES Fischer. \\ 14. Chætetes fructicosa Hall.}

IIl. Dev. Fos. Hall, 1876, pl. 38.

A few specimens of this species were obtained from the upper portion of the Upper and Lower Hamilton.

Other species of Chcetetes were found, but were too imperfect to permit of definite identification.

\section{Subkingdom ECHINODERMATA. Class CRINOIDEA Miller.}

With the exception of three poorly preserved specimens, the crinoids are represented by crinoid joints and a very few plates. No other class of Echinodermata was found.

\section{Genus GRANATOCRINUS Troost.}

15. Granatocrinus (Pentremilis) leda Hall.

Fifteenth Rept. N. Y. State Mus. Nat. Hist., 1862, p. 149, pl. 1.

A complete but badly crushed specimen of this species was found in Zone O. Radial plates were obtained from Zones ' $\mathrm{T}$ and $\mathrm{I}$.

\section{Genus ANCYROCRINUS Hall.}

16. Ancyrocrinus bulbosus Hall.

Fifteenth Rept. N. Y. State Mus. Nat. Hist., 1862, p. 90, pl. 1.

A specimen of this species was found in Zone $\mathrm{I}$.

\section{Genus DICHOCRINUS Münster.}

\section{Dichocrinus sp.?}

A body without arms, from Zone I, was doubtfully referred to this genus.

\section{Crinoid stems and plates.}

The centers of abundance of crinoids, as is shown by the stems, joints, and plates, are, in this section, in Zones D, F, L, M, N, s, and Y. For a faunal study a record of these crinoid remains is as important as the record of any other fossil.

Bryozoa flourished when the conditions were favorable to the development of crinoids. The only exception is Zone F. 


\section{Subkingdorn VERMES. \\ Suborder TUBICOLA. \\ Genus SPIRORBIS Daudin.}

19. Spirorbis angulatus Hall.

Fifteenth Rept. N. Y. State Mus. Nat. Hist., p. 84.

A few casts of this tube were found on an Orthoceras in the upper Marcellus.

\section{Subkingdom MOLLUSCOIDEA. \\ Class BRYOZOA Ehrenberg.}

A number of genera and species of Bryozoa not included in the following list were found. The great amount of time necessary to make accurate identifications, together with the imperfect condition of these fossils, made a more complete list impossible. The centers of abundance of this class are Zones $\mathrm{D}, \mathrm{L}, \mathrm{S}$, and $\mathrm{Y}$.

\section{Order GYMNOLAMATA Allman. Suborder CYCLOSTOMATA Busk.}

Family DIASTOPORID $\approx$ Busk.

Genus HEDERELIA Hall.

20. Hederella canadensis Nicholson.

Pal. N. Y., vol. 6, 1887, p. 277, pl. 65.

A mass of this parasitic bryozoan was found in Zone $\mathrm{Y}$.

Genus REPTARIA Rolle.

21. Reptaria stolonifera Rolle.

G. B. Simpson, Handbook N. A. Pal. Bry., p. 599, pl. 25.

This species was found in the Marcellus shale incrusting an Orthoceras, and in Zone $\mathrm{Y}$ incrusting a goniatite. It is rare in this region.

\section{Suborder CRYPTOSTOMATA Vine.}

Family CYSTODICTYONID $A$ Ulrich.

Genus T AENIOPOIRA Nicholson.

22. Tæniopora exigua Nicholson.

Pal. N. Y., vol. 6, 1887, p. 263, pl. 62.

A few specimens of this species were obtained from Zone $Y$. It is very rare here, and is so reported from Eighteenmile Creek. 


\section{Genus CYSTODICTYA Ulrich.}

23. Cystodictya incisurata Hall.

Pal. N. Y., vol. 6, 1887, p. 241, pl. 40.

This is by far the most abundant bryozoan in the section. In Zone $Y$ almost every piece of shale contains a fragment. It is common in the "Stictopora zone" of Grabau at Eighteenmile Creek.

\section{Family FENESTELLID $\approx$ King.}

\section{Genus POLYPORA McCoy.}

24. Polypora multiplex Hall.

Rept. State Geol. N. Y., 1886, p. 66, pl. 11.

A specimen of this species showing the cellular face was found in Zone S. A great many specimens showing the noncellular face may be of this genus and species, but can not be positively identified as such.

25. Bryozoa, undet.

The distribution of Bryozoa is given under crinoid stems.

\section{Class BRACHIOPODA.}

The classification of Brachiopoda, as given by Schuchert in Bulletin No. 87 of the United States Geological Survey, is used throughout this paper.

Adjustment to environment.-It was found in the study of the faunules of the Hamilton formation that the Brachiopoda were, as a rule, more closely adjusted to their environment than the Pelecypoda. This is shown in the greater definiteness of the faunule combinations of the Brachiopoda and in the often sudden disappearance of every abundant species, and even genera, with an apparently slight change of sedimentation, and their equally sudden reappearance upon the substitution of favorable conditions. The table of faunal zones at the end of the paper makes further comment unnecessary.

\section{Order ATREMATA Beecher.}

\section{Superfamily LINGULACEA Waagen. \\ Family LINGULID E Gray.

\author{
Genus IINGULA Bruguière.
}

26. Lingula delia Hall.

Pal. N. Y., vol. 4, 1867, p. 12, pl. 2.

Zone V (Orbiculoidea zone) contains excellent specimens of this species, fully $25 \mathrm{~mm}$. in length and $16 \mathrm{~mm}$. in width. It is rare in every part of the seetion, but is occasionally found between Zone D and Zone $\mathrm{Y}$. 
27. Lingula densa Hall.

Pal. N. Y., vol. 4, 1867, p. 11, pl. 2.

A specimen from Zone ' $\mathrm{T}$ was more closely related to this than to any other species described by Hall. It measured $12 \mathrm{~mm}$. in length and $8 \mathrm{~mm}$. in width.

28. Lingula ligea Hall.

Pal. N. Y., vol. 4, 1867, p. 7, pl. 1.

Three specimens from Zones I, X, and $Y, 4 . \mathrm{mm} ., 4 \mathrm{~mm} ., 9 \mathrm{~mm}$. in length and $2 \mathrm{~mm} ., 2 \frac{1}{2} \mathrm{~mm}$., and $5 . \mathrm{mm}$. in width, respectively, were referred to this species.

\section{Genus DIGNOMIA Hall.}

29. Dignomia alveata Hall.

(Lingula alveata) Pal. N. Y., vol. 4, 1867, p. 12, pl. 2.

One plainly marked specimen of this species was found in the Encrinal. The same species is reported from the upper portion of the Upper Hamilton at Livonia.

\section{Order TELOTREMATA Beecher. Superfamily RHYNCHONELLACEA Schuchert.}

Family RHYNCHONELIID $A$ E Gray.

Genus CAMARO'IOECHIA Hall and Clarke.

30. Camarotœchia congregata Conrad.

(Rhynchonella congregata) Pal. N. Y., vol. 4, 1867, p. 341, pl. 54.

This species is very rare, being found in but four zones. The specimens are few and so poorly preserved that it is difficult to make a specific identification with certainty.

31. Camarotœchia dotis Hall.

(Rhynchonella dotis) Pal. N. Y., vol. 4, 1867, p. 344, pl. 54A.

In the crystalline limestone of the Encrinal bed, Zone I, a number of specimens possessing the characteristics of this species were found.

32. Camarotœchia horsfordi Hall.

(Rhynchonella horsfordi) Pal. N. Y., vol. 4, 1867, p. 339, pl. 54.

This species was found in the Encrinal bed and in Zone $Y$.

33. Camarotochia prolifica Hall.

(Rhynchonella prolifica) Pal. N. Y., vol. 4, 1867, p. 343, pl. 54A.

Specimens from five zones were referred to this species. The specimens are so crushed that the identification in some cases is doubtful. 
34. Camarotœchia sappho Hall.

(Rhynchonella sappho) Pal. N. Y., vol. 4, 1867, p. 340, pl. 54.

The specimens of this species were well preserved. They were found in the Encrinal bed, Zone D, and in the Cystodictya zone (Y).

\section{Genus HYPOTHXRIS Iring.}

35. Hypothyris cuboides Sowerby.

Pal. N. Y., vol. 8, pt.'2, 1893, p. 200, pl. 60.

(Rhynchonella venustula) Pal. N. Y., vol. 4, 1867, p. 346, pl. 54A.

Nodules almost completely made up of this species were found embedded in the shale on the contact with the Tully limestone. This species was of considerable importance in correlating the Tully limestone with the Upper Devonian of Europe. The occurrence of this species in the Hamilton shales at Cayuga Lake shows that, in this region at least, the migration took place while the muds of the Hamilton formation were still soft, and that the conditions were very favorable for a rapid development.

\section{Genus IEIORHYNCHUUS Hall.}

This genus appeared to be well adapted to conditions unfavorable to all but a few species. In this section it is always found in greatest abundance where other species are rare. The fine muds of the first, second, and third Leiorhynchus and the Orbiculoidea zones were especially favorable for its development. The change of species of this genus between the Marcellus ( $L$. limitare) and the Hamilton ( $L$. laura) did not materially affect the faunules.

36. Leiorhynchus laura Billings.

(L. multicosta Hall) Pal. N. Y., vol. 4, 1867, p. 358, pl. 56.

This species attains its greatest size and abundance in the Orbiculoidea zone (V). In this zone one specimen from a concretion measured $28 \mathrm{~mm}$. in length and $27 \mathrm{~mm}$. in width. Another concretionary layer in the second Leiorhynchus zone (C) afforded large, perfect specimens. It is found throughout the section in thin layers of fine shale. These layers, which are a fraction of an inch thick, are occasionally almost entirely made up of flattened specimens. This is especially true of the first, second, and third Leiorhynchus zones. This species appears immediately above the limestone capping the Marcellus shale. Although L. limitare is very abundant below this limestone, it does' not appear above it. Several doubtful specimens found in Zone $\mathrm{E}$ had somewhat the appearance of $L$. dubium Hall. 
37. Leiorhynchus limitare Vanuxem.

(L. limitaris) Pal. N. Y., vol. 4, 1867, p. 356, pl. 56.

In the Cayuga Lake section this species is confined to the Marcellus, shale. It is preserved in an almost perfect condition in the concretions underlying the falls in Great Gully Creek, near Farleys postoffice.

\section{Superfamily TEREBRATULACEA Waagen.}

Family CENTRONELLID AE Hall and Clarke. Genus CEN'TRONELLA Billings.

38. Centronella impressa Hall.

Pal. N. Y., vol. 4, 1867, p. 402, pl. 61A.

A considerable number of specimens of this species preserved the exterior and interior of the dorsal and the exterior of the ventral valve. The average size is about $14 \mathrm{~mm}$. in length and $11 \mathrm{~mm}$. in width. This rare but strongly marked species is restricted to the Encrinal bed (Zone L) at Cayuga Lake, and is found only in the Encrinal at Eighteenmile Creek.

\section{Family TEREBRATULID $A$ Gray. \\ Subfamily MEGALANTERIN $Æ$ Waagen. \\ Genus CRYPTONELLA Hall.}

39. Cryptonella planirostris Hall.

Pal. N. Y., vol. 4, 1867, p. 395, pl. 61.

A single individual of this species was found in the upper portion of Zone D. At Eighteenmile Creek it is found commonly in the Encrinal and rarely in two zones in the Lower Hamilton.

40. Cryptonella rectirostris Hall.

Pal. N. Y., vol. 4, 1867, p. 394, pl. 61.

The specimens of this species are all somewhai flattened and bear a resemblance to Eunella lincklceni. They are, however, more angular and the beak is not so much incurved as in $E$. lincliceni. They are restricted to Zone D. At Eighteenmile Creek this species is found in a calcareous bed near the base of the Lower Hamilton, but nowhere else in that section. 


\section{Subfamily TEREBRATULIN $A$ Dall.}

Genus EUNFILA Hall and Clarke.

41. Eunella lincklæni Hall.

(Cryptonella lincklceni) Pal. N. Y., vol. 4, 1867, p. 397, pl. 60; vol. 8, pt. 2, p. 290.

This species is restricted to Zones $\mathrm{D}, \mathrm{L}$, and the upper portions of $\mathrm{X}$ and $Y$. The specimens are often exfoliated, but are not crushed and can readily be identified. It is not reported from Livonia or Eighteenmile Creek.

Family TEREBRATELLID $\approx$ King.

\section{Subfamily TROPIDOLEPTIIN $E$ Schuchert.}

Genus TROPIDOLEPTUS Hall.

42. Tropidoleptus carinatus Conrad.

Pal. N. Y., vol. 4, 1867, p. 407, pl. 62.

The characteristic fossil ranges from the Hamilton-Onondaga zone - (A) to the contact of the Tully and Hamilton. In the Cayuga Lake section it seemed to thrive best in the calcareous sediments. Specimens from Zones $\mathrm{Y}, \mathrm{P}$, and $\mathrm{K}$ measured $25 \mathrm{~mm}$. in length and $30 \mathrm{~mm}$. in width, the average size being 20 by $25 \mathrm{~mm}$.

The occurrence of $T$. carinatus in Zone A shows that the migration of this species must have taken place as early as, and probably during, the oscillation which closed Onondaga and began Marcellus time. The changes in level which ushered in the Marcellus must have been widespread, and it is probable that, at this time, the connection between North America and South America was such that a migration of species was permitted. Rathbun's sandstone of Maecurú and Curuá, which contains Anoplotheca flabellites, Vitulina pustulosa and Tropidoleptus carinatus, was correlated with the Marcellus and Onondaga because of the mixture of Onondaga and Hamilton species. Thus far $V$. pustulosa has not been found lower than Zone D, but, accepting Rathbun's correlation, it should be, and may yet, be found as low as $T$. carinatus, if the migration took place at this time.

The only variations noted are between the smaller specimens from the less calcareous shales, which are sometimes almost mucronate, and the large forms of the calcareous shales which are rounded on the cardinal angle. The fact that the young are always less rounded than the older ones indicates that in the finer shales the individuals did not reach maturity.

In eastern New York where the sediments remain of very much the same character throughout the Hamilton and Ithaca groups, T. cari- 
natus extends into the Chemung. In western New York it disappears with the close of the Hamilton. This species, unlike its associate in South America, V. pustulosa, is found in Europe. In North America it has not been reported farther south than Jackson County, Ill.

\title{
Superfamily SPIRIFERACEA Waagen.
}

Family ATRYPID $\mathbb{E}$ Gill.

\author{
Subfamily ATRYPIN $A$ Waagen. \\ Genus ATRYPA Dalman.
}

43. Atrypa reticularis Linnæus.

Pal. N. Y., vol. 4, 1867, p. 316, pl. 51-53A.

This fossil is not by any means a common one in this section. It is abundant in the upper 25 feet below the Tully limestone and common in the Stropheodonta-coralline zone (S). Elsewhere it is seldom seen. The specimens are of the usual form and surface markings.

\section{Family SPIRIFERID $A$ King. Subfamily SUESSIIN $\nexists$ Waagen. Genus CYRTINA Davidson.}

44. Cyrtina hamiltonensis Hall.

Pal. N. Y., vol. 4,1867 , p. 268, pls. 27 and 44.

This is a rare species throughout the section. It is occasionally found in Zone D, but elsewhere it is rare. At Eighteenmile Creek it is common in a few feet of shale near the top of the Lower Hamilton.

\section{Subfamily TRIGONOTRETIN $E$. Schuchert.}

Genus SPIRIFHIR Sowerby.

45. Spirifer audaculus Conrad.

(S. medialis) Pal. N. Y., vol. 4, 1867, p. 227, pl. 38.

The vertical distribution of this species is almost as uniform as that of $S$. pennatus. Hall says that it is an abundant species, coming next to $S$. pennatus in the number of individuals. The greatest abundance of the species, in the Cayuga Lake section, is 20 or 25 feet below the Tully. It is wanting in the second Leiorhynchus zone and very rare in the lower half of the Lower Hamilton. The form is very variable. It is impossible to.tell in poorly preserved individuals whether the specimens are $S$. cuudaculus or $S$. audaculus macronotus. At Eighteenmile Creek it has four zones of abundance, two near 
the base of the Hamilton, one a foot below and one a foot above the Encrinal. In the intervening space between the zones of abundance the species is either very rare or wanting.

46. Spirifer audaculus macronotus Hall.

Pal. N. Y., vol. 4, 1867, p. 231, pl. $38 a$.

This variety of $S$. audaculus is, in its extreme form, readily distinguished from S. audaculus, but the intermediate forms are difficult to determine. In this identification all doubtful forms were called $S$. audaculus.

\section{Spirifer divaricatus Hall.}

Pal. N. Y., vol. 4, 1867, p. 213, pl. 32.

This species was found only in the Encrinal bed (Zone L) and in Zone D. In the former it was not uncommon, but in the latter only one fragment was obtained. The markings of this fossil are so characteristic that there can be no doubt as to the identification. The bifurcating plications and fine imbricating, lamellose striæ are seen in all the specimens. It is reported from the 17 feet of soft shales immediately overlying the Encrinal at Livonia, but has not been noted as occurring at Eighteenmile Creek.

$S$. divaricatus is an Onondaga species which was able to survive the conditions of the Hamilton. Hall and Clarke say that it is the only representative of this type of structure (arrangement of the plications) in the Hamilton faunas, but from the Upper Devonian onward the species multiply rapidly, becoming most abundant and varied in the different faunas of the Lower Carboniferous and continuing until the close of Paleozoic time.

\section{Spirifer granulosus Conrad.}

(S. granulifera Hall) Pal. N. Y., vol. 4, 1867, p. 228, pl. 36; vol. 8, pt. 2, p. 39.

In this section the range of this species is from the first Terebratula zone (D) to the Tully limestone, a distance of over 400 feet. It is found commonly in but three zones, I, L, and $\mathrm{X}$. At Eighteenmile Creek it is wanting in the shales above the Encrinal beds. In this section it is especially common above and including the Encrinal. This is one of a number of species which show how little one can depend on a single species in correlating the smaller divisions of a formation like the Hamilton. Species which are restricted to the Lower Hamilton at Eighteenmile Creek or Livonia are sometimes restricted to the Upper Hamilton in this section or are found throughout the section, or vice versa.

The characters of the species are quite uniform. The variety described by Hall as $S$. clintoni, but not recognized by Schuchert, was found in Zone $\mathrm{T}$. The measurements are: 75 by $55 \mathrm{~mm}$. for the largest and 35 by $20 \mathrm{~mm}$. for the smallest specimens. 
49. Spirifer marcyi Hall.

Pal. N. Y., vol. 4, 1867, p. 226, pl. 37.

This spirifer is confined to the upper 15 feet of this section and is most common within 5 feet of the Tully. It is not reported as occurring below the Encrinal in any part of the State. The largest specimen measured $90 \mathrm{~mm}$. in width and $30 \mathrm{~mm}$. in length. No other spirifer found in this section is so well preserved and so striking. This fossil has not been found at Eighteenmile Creek. Clarke reports it in the upper 160 of the Hamilton of the Livonia salt shaft section. It is found in the upper 50 feet of the Upper Hamilton in the Kashong (Seneca Lake) section.

\section{Spirifer pennatus Atwater.}

(S. mucronata) Pal. N. Y., vol. 4, 1867, p. 216, pl. 34.

No other species is found so commonly from Zone D to the Tully limestone as is this one. It is wanting only in the fine shales of Zone $Q$, the $1 \frac{1}{2}$ feet of crystalline Encrinal beds, and in Zone E. In the Eighteenmile Creek section it is common below the Encrinal but extremely rare above.

S. pennatus, at Cayuga Lake, is variable in three particulars: (1) Gibbosity; (2) surface markings; (3) in the length of the mucronations. These variations are not progressive. A specimen which is gibbous is usually shorter and has fewer but stronger imbrications than the mucronate and flat kinds. There is no difficulty at any time in distinguishing the extremes of this species as developed at Cayuga Lake from Delthyris consobrina on the one hand and Spirifer audaculus on the other.

\section{Spirifer tullius Hall.}

(S. tullia) Pal. N. Y., vol. 4, 1867, p. 218, pl. 35.

Spirffer tullius is not abundant in any part of the section nor has it a great vertical range. With the exception of five or six specimens, which were found immediately below the Encrinal beds, the species is confined to the Upper Hamilton.

The characteristic fine striations are usually distinct except in the Encrinal, where the shell has been exfoliated in working it out of the limestone. One of the largest specimens from Zone I measured 16 $\mathrm{mm}$. in width and $14 \mathrm{~mm}$. in length. One specimen from Zone I measured $17 \mathrm{~mm}$. in width and 13 or $14 \mathrm{~mm}$. in length.

52. Spirifer macrus Hall.

(S. macra) Pal. N. Y., vol. 4, 186'7, p. 190, pl. 27.

This species was found only in Zone A, 12 feet above the Onondaga (Corniferous) limestone. It is associated with Onondaga and Hamilton fossils. (See Zone A.) 


\section{Genus DELTHYRIS Dalman.}

53. Delthyris consobrina d'Orbigny.

(Spirifera ziczac) Pal. N. Y., vol. 4, 1867, p. 222, pl. 35.

Spirifer pennatus occasionally approaches this species in its form and surface markings, the imbricating lamellæ being sometimes strongly arched and finer than normal. The number of plications of D. consobrina is, however, always less. In this section there is no difficulty in distinguishing between the extreme forms of the two species. This fossil is fairly common in Zones $R$ and $S$, but is rare elsewhere in the section. At Eighteenmile Creek it is found only above the Encrinal, where it is restricted to two zones. It is not reported from Livonia.

54. Delthyris sculptilis Hall.

(Spirifera sculptilis) Pal. N. Y., vol. 4, 1867, p. 221, pl. 35.

This species is not uncommon in a weathered layer of the upper part of Zone D. It was not found elsewhere in the section. At Eighteenmile Creek it occurs only in the Encrinal. At Livonia it is found in two zones above the Encrinal.

\section{Genus MARTINIA MICCoy.}

55. Martinia subambona Hall.

(Spirifera subumbona) Pal. N. Y., vol. 4, 1867, p. 234, pl. 33.

A very few specimens of this species were found in Zone $T$. The surface markings could not be made out, but the general form was in accord with the descriptions. One specimen measured $15 \mathrm{~mm}$. in length and $15 \mathrm{~mm}$. in width.

\section{Genus AmBOC'CHI A Hall.}

56. Ambocelia præumbona Hall.

Pal. N. Y., vol. 4, 1867, p. 262, pl. 44.

This species has a very limited vertical range in this section. It is found in Zone $U$ as a center and a foot or two above and below. The specimens are rather smaller than the type specimens, but are quite characteristic. At Livonia it is restricted to the Upper Hamilton, and is common in but one zone, 48 feet thick, the lowest part of which is 17 feet above the Encrinal. It is rarely found above this. At Eighteenmile Creek it is restricted to the $3 \frac{1}{2}$ feet at the top of the Upper Hamilton. It might be inferred from its occurrence in these three sections that it is a characteristic Upper Hamilton fossil. In the Kashong (Seneca Lake) section it is restricted to the upper portion of the Upper Hamilton. The fact that it has not been found east of Cayuga Lake or west of New York State indicates that it originated in this region. 
57. Ambocœlia umbonata Conrad.

Pal. N. Y., vol. 4, 1867, p. 259, pl. 44.

The gregarious character of this species is well shown in a description in one of the old New York reports. ${ }^{\prime}$ In speaking of the shale at Eighteenmile Creek, Hall says: "The lower part of this shale resting on the Encrinal beds is completely filled with a small Orthis or Stenecesma (Ambocolia umbonata). This species so abounds that in some places there is scarcely enough shaly matter to cause the mass to cohere." In the second Ambocoelia zone (R), described elsewhere, A. umbonata has a remarkable development. Elsewhere in the section layers an inch or less in thickness were found which were almost completely made up of them. In actual numbers there are a great many more $A$. umbonata than any other fossil. It extends from Zone A to Zone $\mathrm{Y}$. Its vertical range is equally great at Livonia and at Eighteenmile Creek. The absence of Tropidoleptus carinatus wherever. A. umbonata flourishes, and vice versa, is noticeable both here and at Eighteenmile Creek. Phacops rana is an associated fossil.

The variations of this species are principally confined to surface markings, although variation in size is common.

Dr. J. M. Clarke describes A. spinosa from the Livonia section: ${ }^{b}$ "Surface bearing faint traces of concentric lines and covered with numerous elongate depressions which were probably the bases of insertion of epidermal spines." A number of individuals answering this description fairly well were found in Zone $U$, but were included with $A$. umbonata. Specimens covered with elongated pits resembling A. umbonata var. nana, ${ }^{c}$ described by Grabau, have also been included with $A$. umbonata.

\section{Genus RETICULARIA McCoy.}

58. Reticularia fimbriata Conrad.

(Spirifer fimbriata) Pal. N. Y., vol. 4, 1867, p. 214, pl. 33.

In this section $R$. fimbriata extends from Zone $D$ to Zone $\mathrm{Y}$, but is never abundant. Aside from Zones $D, N$, and $Y$ it is very rare. At Livonia it is not reported lower than the Encrinal, while at Eighteenmile Creek it does not occur above the Encrinal.

\section{Family ATHYRID $A$ Phillips. \\ Subfamily HINDELLIN $A$ Schuchert. \\ Genus NUCLEOSPIRA Hall. \\ 59. Nucleosipira concinina Hall.}

Pal. N. Y., vol. 4,1867 , p. 279 , pl. 45.

This is a rare species in all parts of the section, and although it occurs in the highest zone (Y) and in Zone D, it was found in but two

a Fifth Annual Report, Geol. Sur. N. Y., 1841, p. 164

b Report N. Y. State Geol., vol. 1, 1893, p. 177, pl. 4.

c Sixteenth Ann. Report State Geol: N. Y., 1898, p. 277.

Bull. 206-03-4 
other zones-S and L. The specimens have either the surface markings preserved or the muscular scars distinct.

At Livonia it is reported as occurring only in a concretionary layer 50 feet above the Encrinal. At Eighteenmile Creek it is very common in the upper foot of the Lower Hamilton.

\section{Genus ANOPLOTHECA Sandberger.}

60. Anoplotheca camilla Hall.

(Coeleospira camilla) Pal. N. Y., vol. 4, 1867, p. 329, pl. 52.

This species was found at the base of the Marcellus, in Zone A, associated with Hamilton and Onondaga (Corniferous) species. Two individuals measured $6 \cdot \mathrm{mm}$. and $5 \frac{1}{2} \mathrm{~mm}$. in length and $6 \mathrm{~mm}$. and $5 \frac{1}{2}$ $\mathrm{mm}$. in width, respectively.

A layer of limestone 9 feet above the Onondaga limestone, in the Livonia salt section, contained this same species associated with an even more characteristic Hamilton fauna, but it does not appear in the typical Hamilton faunules.

\section{Genus VIrTUIINA Hall.}

\section{Vitalina pustulosa Hall.}

Pal. N. Y., vol. 4, 1867, p. 410, pl. 62.

In the Cayuga Lake section Vitulina pustulosa is restricted to the Encriual beds and Zone D, two rather thin zones over 150 feet apart, and to the Encrinal bed at Eighteenmile Creek. Prof. C. S. Prosser reports it as occurring in Schoharie County in the uppermost portion of the Hamilton, ${ }^{a}$ and in what is apparently the Lower Hamilton, at Marshall Falls post-office in eastern Pennsylvania. ${ }^{b}$

In South America this species occurs throughout, not only what is correlated with the Hamilton, but the entire Devonian. In Bolivia it is reported by Steinmann from the "Conularia Schichten," which he correlated with the Onondaga and Marcellus, and in the Huamampampa sandstone, which is correlated with and includes the Hamilton, the Upper Devonian, and perhaps the Lower Carboniferous. In Brazil it is found in the sandstone of Maecurú and Curuá (Onondaga and Marcellus) and in the Erere sandstone.(Hamilton) of Rathbun. In middle Argentina, Kayser found it in the "Kalkig sandig Banke" of "O. von Jachalthal" (Onondaga and Marcellus). In South Africa it was collected by Schenk in the Bokkenveld Mountains. At the present writing it has not been reported from Europe.

Two specimens from Zone D, at Cayuga Lake, measured 10 and $8 \mathrm{~mm}$. in width, 8 and $6 \mathrm{~mm}$. in length, and 4 and $3 \mathrm{~mm}$. in thickness. Two specimens from the Encrinal measured 11 by $7 \mathrm{~mm}$. and 11 by $10 \mathrm{~mm}$. 
In the Cayuga Lake section this species in confined to two calcareous layers, Zones D and L. At Kashong Creek it occurs in the fine shales underlying the Tully and in the fine black shales overlying the "Basal limestone."

\section{Subfamily ATHYRINA Waagen. \\ Genus ATHYRIS McCoy. \\ 62. Athyris spiriferoides Eaton.}

Pal. N. Y., vol. 4, 1867, p. 285, pl. 46.

This fossil is very common from the lower part of Zone I, 80 feet below the Encrinal bed, to the top of Zone X. Below this zone it was found in Zone $\mathrm{A}$ and in Zone $\mathrm{D}$; elsewhere it is very rare.

\section{Subfamily MERISTELLIN $A$ Waagen. \\ Genus MERISTELLA Fall.}

63. Meristella haskinsi Hall.

Pa1. N. Y., vol. 4, 1867, p. 306, pl. 49.

Specimens $22 \mathrm{~mm}$. long and $20 \mathrm{~mm}$. wide were found in the Encrinal bed and in Zone D. A portion of the shell was preserved, showing the wrinkled concentric lines which are crowded in front. On the exfoliated surface the faint radiating lines can be seen. This species has not been reported east of Seneca Lake nor west of Thedford, Canada. It was found only in the Encrinal at Eighteenmile Creek. It occurs in the "Basal limestone" of Slate Rock River (Seneca Lake section).

\section{Order NEOTREMATA Beecher.}

\section{Superfamily DISCINACEA Waagen. \\ Family DISCINID AE Gray. \\ Genus ORBICULOIDEA d'Orbigny.}

64. Orbiculoidea doria Hall.

(Discina doria) Pal. N. Y., vol. 4, 1867, p. 19, pl. 2.

- Several specimens were referred to this species with some doubt. The specimens at hand have a more elevated apex and are smaller than is usual in $O$. media. This species is restricted to one zone at Eighteenmile Creek.

65. Orbiculoidea humilis Hall.

(Discina humilis) Pal. N. Y., vol. 4, 1867, p. 16, pl. 2.

A fragment of a large Orbiculoidea from Zone $J$ was referred to this species. 
66. Orbiculoidea lodiensis Vanuxem.

(Discina lodensis) Pal. N. Y., vol. 4, 1867, p. 22, pl. 2.

This species so closely resembles $O$. medici that it is difficult to distinguish between them. The faint radiating lines are seen in specimens from Zone T. It is a rare species at Eighteenmile Creek, and is found in but two zones.

\section{Orbiculoidea lodiensis media Hall.}

(Discina lodensis) Pal. N. Y., vol. 4, 1867, p. 20, pl. 2.

This is a very common species in the Orbiculoidea zone (V). The concretionary layer, in which they are very large, abundant, and well preserved, was traced for a distance of 10 miles. Above and below this zone this fossil is found occasionally, but in no other zone in such abundance.

The Orbiculoidea media bed of Grabau, 5 feet above the Encrinal, is the only layer in which it is reported as common at Eighteenmile Creek.

\section{Superfamily CRANIACEA Waagen. \\ Family CRANIID $A$ King. \\ Genus CRANIEIIAA Oehlert.}

68. Craniella hamiltoniæ Hall.

Pal. N. Y., vol. 4, 1867, p. 27, pl. 3.

This is not an uncommon species in the upper part of Zone Y. Elsewhere in the section it is rarely found. It is a rare fossil at Eighteenmile Creek and Livonia.

\section{Genus PHOIIDOPS Hall.}

69. Pholidops hamiltoniæ Hall.

Pal. N. Y., vol. 4, 1867, p. 32, pl. 3 .

This is a common fossil between Zones $\mathrm{X}$ and $\mathrm{I}$, with the exception of the limestone of the Encrinal band. Below Zone I it was not found. The extremes in size are $3 \mathrm{~mm}$. in length and $2 \mathrm{~mm}$. in width for the smallest, and $4 \mathrm{~mm}$. in length and $3 \mathrm{~mm}$. in width for the . largest, specimens. The vertical range at Eighteenmile Creek and Livonia is about the same as at the Cayuga Lake section, the center of abundance in those sections being in the upper part of the Lower Hamilton.

70. Pholidops oblata Hail.

(P. oblata and linguloides) Pal. N. Y., vol. 4, 1867, p. 414, pl. 3.

The only specimen of this species, found in Zone $\mathrm{L}$, showed the interior of the ventral (?) valve, but the muscular scars were oblit- 
erated. Following Schuchert, $P$. linguloides and $P$. oblata will be considered as the same species. At Eighteenmile Creek it was found in the Encrinal and in a zone 1 foot below. It was not reported from Livonia. Size $4 \frac{1}{2} \mathrm{~mm}$. wide and $5 \frac{1}{2} \mathrm{~mm}$. long.

\title{
Order PROTREMATA Beecher.
}

\section{Superfamily STROPHOMENACEA Schuchert.}

\author{
Family RAFINESQUININ A Schuchert.
}

\section{Genus STROPHEODOŃTA Hall.}

\section{Stropheodonta concava Hall.}

Pal. N. Y., vol. 4, 1867, p. 96, pl. 16.

This species is restricted to three narrow zones, $\mathrm{X}$ and $\mathrm{Y}$, and $\dot{\mathrm{S}}$, in the Upper Hamilton. The specimens are well preserved and show the characteristic form and surface markings. Both full-grown and young individuals were collected. The immature specimens do not possess the concavity of the mature individuals, but approach $S$. demissa in form. In both zones where $S$. concava is found, Streptelasma rectum is common.

At Eighteenmile Creek this species is rarely found below, and not above, a zone 6 inches thick a foot below the Encrinal. At Livonia it is common in three zones above, and including, the Encrinal, and rarely in two other zones. It is not reported from the Lower Hamilton.

Size $60 \mathrm{~mm}$. in width and $55 \mathrm{~mm}$. in length for the mature, and $40 \mathrm{~mm}$. in width and $30 \mathrm{~mm}$. in length for the immature, forms.

\section{Stropheodonta demissa Conrad.}

Pal. N. Y., vol. 4, 1867, p. 101, pl. 17.

The only specimen of this species was found in Zone I. At Eighteenmile Creek, with few exceptions, it is restricted to 6 inches of shale in the Lower Hamilton within a foot of the Encrinal bed. It is reported as occurring only in the Encrinal at Livonia.

Size $30 \mathrm{~mm}$. in width and $20 \mathrm{~mm}$. in length.

73. Stropheodonta inæquistriata Conrad.

Pal. N. Y., vol. 4, 1867, p. 106, pl. 18.

This species is found in the upper 25 feet of the Hamilton, in Zone S, in the Encrinal bed, in Zone I, and, rarely, in Zone D. Between these zones it is rare. Little variation, except in size, is noticeable in the specimens from the different zones.

The width along the cardinal lines of the largest specimen was $40 \mathrm{~mm}$. and the length $28 \mathrm{~mm}$. A smaller specimen measured $13 \mathrm{~mm}$. in width and $10 \mathrm{~mm}$. in length.

At Eighteenmile Creek and Livonia it is common, but has very much the same vertical distribution. 
74. Stropheodonta junia Hall.

(Stropheodonta textilis) Pal. N. Y., vol. 4, 1867, p. 108, pl. 18.

This species is confined to the upper 35 feet of the Upper Hamilton, with the exception of a few specimens in Zone $\mathrm{N}$. The specimens are large and well preserved. It is especially abundant at Lake Ridge in the calcareous shales immediately under the Tully limestone.

At Eighteenmile Creek it is rarely found, in a single zone, a foot below the Encrinal. It is reported as occurring quite commonly in the upper. 200 feet of the Upper Hamilton at Livonia, but is not reported from the Lower Hamilton.

\section{Stropheodonta perplana Conrad.}

Pal. N. Y., vol: 4,1867 , p. 98 , pls. $11,12,17$, and 19.

This species is more abundant in this section than $S$. inoequistriata with which it is usually associated. The largest individuals occur in the limestone concretions of the Upper Hamilton. At Eighteenmile Creek it is a common fossil, but is not as abundant as S. demissa, a species which is seldom seen in the Cayuga Lake section. S. perplana is found throughout the Hamilton of the Livonia section.

\section{Stropheodonta perplana var.}

A single specimen with long, mucronate points, but with the characters of the coarser varieties of $S$. perplana, will not be given a varietal name until more individuals are found. It is possible that the mucronations were due to some disease of the animal. The length of the shell along the hinge line is $42 \mathrm{~mm}$., the width of the body $18 \mathrm{~mm}$., and the length of the shell $14 \mathrm{~mm}$.

\section{Genuṣ PHOLIDOSTROPHIA Hall and Clarke.}

\section{Pholidostrophia iowaensis Owen.}

(Stropheodonta nacrea Hall) Pal. N. Y., vol. 4, 1867, p, 104, pl: 18.

With the exception of the lower part of Zone I, where it is common, this species is very rare in the Cayuga Lake section. It is found rarely in Zones $\mathrm{N}$ and $\mathrm{Y}$.

At Eighteenmile Creek it is found in both the Upper and Lower Hamilton. At Livonia it is reported from the Encrinal and from two zones 65 and 90 feet above. At Kashong Creek it occurs both above and below the Encrinal beds, but never in abundance.

\section{Subfamily ORTHOTHETIN $\nexists$ Waagen.}

\section{Genus ORIPHO'PHETHS Hischer de Waldheim.}

78. Orthothetes chemungensis var. arctistriatus Hall.

(Streptorhynchus chemungensis arctostriata) Pal. N. Y., vol. 4, 1867; p. 71, pl. 9.

This variety, though seldom common, is found in almost every zone in the Upper Hamilton, and is not uncommon; with the exception of 
Zone $\mathbf{E}$, in the Lower Hamilton above Zone D. It is quite constant in its form and surface markings. At Eighteenmile Creek it is scattered throughout the section from the lowest to the highest zone. It is rare above the Encrinal, but common in several zones below. At Livonia it is commoner above than below the Encrinal beds.

79. Orthothetes chemungensis var. perversus Hall.

(Streptorhynchus chemungensis perversus) Pal. N. Y., vol. 4, 1867, p. 72, pl. 9.

This fossil was not found above and rarely below the Encrinal beds at Cayuga Lake. This variety is readily distinguished from $O$. chemungensis arctistriatus by its larger form and surface markings. It is rare at Eighteenmile Creek, where it is found only below the Encrinal.

80. Orthothetes chemungensis var.

A variety of Orthothetes approaching Hall's type, Streptorhynchus pectinacea, was found in Zone A. All of the specimens are casts, or show only the interior of the shell. One very good specimen measures about $10 \mathrm{~mm}$. in length, $15 \mathrm{~mm}$. in width, and the carcinal area $2 \mathrm{~mm}$. high. In this specimen there are seventeen prominent striæ, with from two to no weak striz between. The surface is marked by very fine undulating concentric lines.

\section{Family PRODUCTID $\approx$ Gray. \\ Subfamily CHONETIN $\nexists$ Waagen. \\ Genus CHONHTES Fischer de Waldheim.}

81. Chonetes coronatus Conrad.

Pal. N. Y., vol. 4, 1867, p. 133, pl. 21.

A single specimen of dorsal valve of this species was found in Zone A, associated with Onondaga (Corniferous) species. With the exception of this zone and Zone D, it was not found below Zone $\mathrm{H}$. Between Zone $\mathrm{H}$ and $\mathrm{T}$ it has its greatest abundance. In the upper 10 feet of the Upper Hamilton it is extremely rare.

At Livonia it is reported from the Encrinal and above, but was not found in the Lower Hamilton. With the exception of the Encrinal and a foot of shale immediately below, this species is rare at Eighteenmile Creek.

82. Chonetes lepidus Hall.

Pal. N. Y., vol. 4, 1867, p. 132, pl. 21.

This species is sometimes not easily distinguished from the young individuals of other species of Chonetes. Specimens from Zones X and $\mathrm{Y}$ possess a number of points of differences from the typical C. lepidus, but may be of this species. On page 133 of vol. 4, Pal. N. Y., Hall says that the original specimens designated as C. lepida 
are very small, almost hemispheric shells. The striæ are very strong, angular, etc. This description accords fairly well with the specimens in question.

At Eighteenmile Creek $C$. lepidus is the most common species of Chonetes in the Hamilton shale. "It is everywhere abundant, in some layers extremely so." $a$ This species is not so common at Cayuga Lake as either $C$. scitulus, $C$. mucronatus, or $C$. vicinus. It is found in all the zones of the Upper Hamilton with the exception of the Encrinal bed. In the Lower Hamilton it is not common in any zone and is entirely wanting in the lower half of Zone $\mathrm{C}$.

\section{Chonetes lineatus Conrad.}

Pal. N. Y., vol. 4,1867 , p. 121 , pl. 20.

This Onondaga (Corniferous) species was found in Zone A, where it is very common. It was associated with Anoplotheca camilla, S. macrus, Chonetes coronatus, C. mucronatus, and Ambocclia umbonata.

84. Chonetes mucronatus Hall.

Pal. N. Y., vol. 4, 1867, p. 124 , pls. 20 and 21.

This species is very common in the lowest zone in the section, Zone A. It is met with rarely in Zone $C$, and is common in the first Terebratula zone. Above this to the Encrinal its place is taken by Chonetes vicinus. In the Upper Hamilton it is a very common and well-preserved fossil. C. mucronatus is not common at Eighteenmile Creek, "where it is nearly restricted to the lower Moscow shales." At Livonia it is not reported from the Upper Hamilton, but is found in the Lower Hamilton.

85. Chonetes scitalus Hall.

Pal. N. Y., vol. 4, 1867, p. 130, pl. 21.

This species comes next to $C$. mucronatus in abundance in this section. It is rarely found in the first and second Leiorhynchus zones, but is common especially in the lower half of the Upper Hamilton.

At Livonia it is common throughout the Upper and Lower Hamilton, while at Eighteenmile Creek it is common in the Lower but rare in the Upper Hamilton.

86. Chonetes setigerus Hall.

Pal. N. Y., vol. 4, 1867 , p. 130, pl. 21.

A single specimen of this species was found in Zone ' $T$.

87. Ohonetes vicinus Castelnau.

(C. deflecta, Hall), Pal. N. Y., vol. 4, 1867, p. 128, pl. 21.

King Ferry station is one of the type localities for this species. As dereloped here it is distinguished from $C$. mucronatus by its larger 
size and greater number and fineness of the striæ. The average size is $7 \mathrm{~mm}$. in length and $13 \mathrm{~mm}$. in width. It is an exceptionally abundant species in the first 115 feet below the Encrinal It was not found above or below this zone.

At Eighteenmile Creek it is common in one zone 2 or 3 feet above the Encrinal, but is rare in the Lower Hamilton. At Livonia it is found throughout the section, with the exception of the upper 160 feet of the Upper Hamilton.

87a. Chonetes sp.

A specimen which could not be referred to any described species of Chonetes was found in Zone I. The size is $4 \mathrm{~mm}$. in length and 7 $\mathrm{mm}$. in width. $“$ The striæ are fine and round and number 32 . The spaces between the striæ have a reticulate appearance.

\section{Subfamily PRODUCTIN $Æ$ Waagen. \\ Genus. PRODUCrFELAA Hall.}

88. Productella spinulicosta Hall.

Pal. N. Y., vol. 4, 1867, p. 160, pl. 23.

This is a widespread but not an abundant species in this section, being found in almost every zone from Zone $D$ to the Tully limestone. It was found in the arenaceous shales of the Marcellus, but is wanting in the fine shales of Zone C, its place being taken by Strophalosiu truncata. A specimen from Zone $\mathrm{Y}$ bears a strong resemblance to $P$. lachrymosa (Conrad) of the Chemung and may be of that species. $P$. spinulicosta is an extremely variable species.

\section{Productella navicella Hall.}

Pal. N. .Y., vol. 4, 1867, p. 156, pl. 23.

A few specimens from concretionary layers in the upper part of Zone C, about 65 feet below Zone D, in Dean Creek, were referred. provisionally to this species. The arcuate form, small size, and the position of the spines accord well with the description given by Hall.

\section{Genus STIROPIAÃIOSIA King.}

90. Strophalosia truncata Hall.

(Productella truncata) Pal. N. Y., vol. 4, 1867, p. 160, pl. 23.

This species was found in the Marcellus shales and continued up into the barren shales of Zone $\mathrm{E}$. In one layer in Zone $\mathrm{C}$, a fraction of an inch thick, it occurs in great abundance. At Eighteenmile Creek it is found in the Marcellus shales and rarely in the next zone above. 


\section{Family ORTHID $A$ W Woodward. \\ Genus RHIPIDOMHLLA Oehlert. \\ 91. Rhipidomella vanuxemi Hall.}

(Orthis vanuxemi) Pal. N. Y., vol. 4, 1867, pp. 40, 47, pl. 5.

This is a very common species in the Upper Hamilton in the Cayuga Lake section, but was found in only one zone in the Lower Hamilton. It has the same range at Livonia as at Cayuga Lake, except that it is not reported from the shales below the Encrinal.

At Eighteenmile Creek it is one of the commonest fossils in the Lower Hamilton and is found rarely, and in but one zone, above the Encrinal.

At Cayuga Lake, with the exception mentioned above, no rhipidomellas are found in the Lower Hamilton. This is true of the Livonia section with the exception' of $R$. lenticularis (?), which is reported as common in a mixed Onondaga (Corniferous) and Hamilton faunule at the base of the Lower Hamilton.

92. Rhipidomella cyclas Hall.

Pal. N. Y., vol. 4, 1867, p. 52, pl. 7.

One specimen from Zone $\mathrm{T}$ was identified as this species. The striæ are sharper and fewer and the hinge line longer than in the small forms of $R$. vanuxemi.

\section{Rhipidomella penelope Hall.}

Pal. N. Y., vol. 4, 1867, p. 50, pl. 6.

One specimen from Zone $\mathrm{Y}$ is referred to this species because of its larger size. The surface markings were obliterated. It may prove to be a large individual of $R$. vanuxemi.

This species is common at Kashong and Eighteenmile creeks.

\section{Superfamily PENTAMERACEA Schuchert.}

Family PENTAMERID $\not$ McCoy.

Genus PENTAMHREILA Hall.

93a. Pentamerella pavilionensis Hall.

Pal. N. Y., vol. 4, 1867, p. 377, pl. 58.

A. few badly crushed specimens of this species were found in the lower portion of Zone D. It is not uncommon in the Encrinal beds of the Seneca Lake section. 


\section{Subkingdom MOLLUSCA.}

\section{Class PELECYPODA Goldfuss.}

The Pelecypoda in this paper are classified according to Dall, as given in Eastman's translation of Zittel's "Text Book of Palæntology," 1900. Genera which are not mentioned in the text-book are placed with the most closely allied forms. Such additions are indicated by a question mark before each genus so referred.'

Adjustment to environment.-The Pelecyporla of the Hamilton seemed to be very much less closely adjusted to their environment than the Brachiopoda, as is shown by the fact that an apparently slight change of environment was sufficient to produce a great abundance or almost total extinction of certain genera of Brachiopoda, whereas the Pelecypoda often survived several changes of these brachiopod faunules and were never abundant.

\section{Order PRIONODESMACEA Dall.}

\section{Family SOLEMYACID \& Dall.}

\section{Genus PHTHONIA Fall.}

94. Phthonia nodicostata Hall.

Pal. N..Y., vol. 5, pt. 1, 1885, p. 474, pl. 78.

Two specimens of this species were found in Zone M. They measured 23 and $20 \mathrm{~mm}$. in length.

95. Phthonia cylindrica Hall.

Pal. N. Y., vol. 5, pt. 1, 1885, p. 473, pl. 78.

A single individual of this species was found in each of three zones. Two of these measured 17 and $21 \mathrm{~mm}$. in length, and 8 and $10 \mathrm{~mm}$. in height, respectively.

96. Phthonia sectifrons Conrad.

Pal. N. Y., vol. 5, pt. 1, 1885, p. 475, pl. 78.

A right valve of this species, with the surface markings well preserved, was found in Zone $\mathbf{Y}$.

Family SOLENOPSID $A$ Neumayr.

Genus OR'THONOTA Conrad.

97. Orthonota carinata Conrad.

Pal. N. Y., vol. 5, pt. 1, 1885, p. 479, pl. 78.

This well-marked species was found rarely in two zones in the Upper and two in the Lower Hamilton. 
98. Orthonota undulata Conrad.

Pal. N. Y., vol. 5, pt. 1, 1885 , p. 478, pl. 78.

This species was found in both the Upper and Lower Hamilton. Five specimens measured $64,62,57,40$, and $27 \mathrm{~mm}$. in length and 16, $15,15,10$, and $8 \mathrm{~mm}$. in height, respectively.

99. Orthonota (?) parvula Hall.

Pal. N. Y., vol. 5, pt. 1, 1885, p. 482, pls. $65,78$.

This species is rare in every part of the section, but is found in a number of zones in both the Upper and Lower Hamilton above Zone D. At Livonia it was found in the upper 160 feet of the Hamilton and in one other zone above the Encrinal.

\section{Genus PRO'THYRIS Meek. \\ 100. Prothyris lanceolata Hall.}

Pal. N. Y., vol. 5, pt. 1, 1885, p. 460, pl. 76.

This is a very rare species in this section. The largest specimen measured $25 \mathrm{~mm}$. in length and $10 \mathrm{~mm}$. in height, the smallest about $10 \mathrm{~mm}$. in length and $2 \frac{1}{2} \mathrm{~mm}$. in height.

101. Prothyris truncata sp. nov.

Shell small, rectangulate, length more than twice the height. Basal margin nearly straight and truncate behind, cardinal line long, straight, essentially parallel to the basal margin. Anterior end limited from the body by a low, narrow fold. Valves almost flat. Beaks very inconspicuous. A well-marked diagonal ridge is situated slightly posterior to the beak. Shell marked by faint concentric stria, which are somewhat fasciculate along the basal margin.

Three specimens measured 13,11 , and $10 \mathrm{~mm}$. in length, and 5, 3, and $3 \mathrm{~mm}$., respectively, in height.

This species differs from $P$. lanceolata in its truncated posterior extremity and in the diagonal ridge; from $P$. planulata in the flatness of the valves and the absence of an angular umbonal slope.

Family GRAMMYSIID $\mathbb{A}$ Fischer.

Genus GRAMMYSIA de Verneuil.

102. Grammysia constricta Hall.

Pal. N. Y., vol. 5, pt. 1, 1885, p. 377, pls. 59 and 78.

This species is rare throughout the section, and was not found below Zone D. The surface markings vary from almost continuous radiating lines to widely separated pustules, which can hardly be said to present a radiating appearance. 
103. Qrammysia cuneata Hall.

Pal. N. Y., vol. 5, pt. 1, 1885, p. 383, pls. 62 and 93.

This species, like all species of Grammysia, is far from common in any portion of the section.

104. Grammysia arcuata Conrad.

Pal. N. Y., vol. 5, pt. 1, 1885, p. 373, pls. 61, 63, and.93.

Ten or 15 feet below the Encrinal this species is quite common, elsewhere it is rare. Three valves (one of which measures fully $80 \mathrm{~mm}$. in length) from Zone $\mathrm{Y}$ answer the description of $G$. subarcuata of the Chemung fairly well, but were included in $G$. arcuata.

105. Arammysia bisalcata Conrad.

Pal. N. Y., vol. 5, pt. 1, 1885, p. 359, pls. 56 and 93.

A few specimens of this species were found in Zone G. It is reported from the upper 160 feet of the Upper Hamilton at Livonia.

\section{Genus FIIMMILIA Fall. \\ 106. Elymella fabalis Hall.}

Pal. N. Y., vol. 5, pt. 1, 1885, p. 502, pl. 40.

Two valves from Zone $\mathrm{Y}$ are referred to this species. The anterior end is rather too long for $E$. fabalis, but may be a variation.

107. Elymella nuculoides Hall.

Pal. N. Y., vol. 5, pt. 1, p. 503, pl. 40.

A few specimens of this species were found in Zone $\mathrm{X}$.

\section{Genus, GIOSSITHES Iall.}

108. Glossites subtennis Hall.

Pal. N. Y., vol. 5, pt. 1, 1885, p. 495, pl. 40.

There is some doubt as to the correctness of the identification of the specimen referied to this species.

\section{Genus THLLINOPSIS Hall.}

109. Tellinopsis subemarginata Conrad.

Pal. N. Y., vol. 5, pt. 1, 1885, p. 464. pl. 76.

This species is common in Zone $\mathrm{X}$, the center of Zone $\mathrm{T}$, Zone $\mathbf{J}$, Zone $\mathrm{G}$, and the lower portion of Zone D. It is never abundant and seldom common, but is found in almost all the zones in this section.

At Eighteenmile Creek a single specimen was found. It is reported from four zones in the Upper Hamilton of the Livonia section.

Two large specimens were 45 and $30 \mathrm{~mm}$. long and 27 and $17 \mathrm{~mm}$. wide. 


\title{
Family CARDIOLID
}

\author{
Genus PANFNIKA Barrande.
}

110. Panenka lincklæni Miller.

Pal. N. Y., vol. 5, pt. 1, p. 420, pl. 69.

The specimen which was refêrred to this species is probably a new species. It differs from $P$. linckloeni in the broad concave plications, the almost flat interspaces, and the absence of intermediate radii. Both plications and interspaces are crossed by fine concentric lines. Found in Zone $\mathrm{T}$.

\section{i11. Panenka potens Hall.}

Pal. N. Y., vol. 5, pt. 1, 1885, p. 422, pl. 69.

A very.imperfect specimen about $60 \mathrm{~mm}$. in height is doubtfully referred to this species. It was found associated with Lunulicardium curtum and $L$. ornata in Zone $\mathrm{C}$.

112. Panenka sp. undet.

A small, well-preserved cast of a Panenka from Zone $\mathrm{X}$ does not answer the description given in the New York Paleontology. It is about $12 \mathrm{~mm}$. high and of the same length. The plications number 22 and reach the beak. Faint concentric lines can be seen. This specimen bears a resemblance to $P$. retusa, which is reported from Cayuga Lake. The plications of $P$. retusa, however, number 35, with narrow interspaces, while the size is $30 \mathrm{~mm}$. in length and $31 \mathrm{~mm}$. in height.

Genus GIYPTOCARDIA Hall.

113. Glyptocardia speciosa Hall.

Pal. N. Y., vol. 5, pt. 1, 1885, p. 426, pls. 70 and 80 .

This species is found occasionally in Zones T, F, and E; elsewhere in the section it is very rare or wanting. The largest specimen from Zone $\mathrm{F}$ measured $11 \mathrm{~mm}$. in height. It is not reported from Eighteenmile Creek or Livonia.

\section{Superfamily NUCULACEA.}

\section{Family (?) CTENODONTID A Dall. \\ Genus NUCULITHES Conrad. \\ 114. Nuculites triqueter Conrad.}

Pal. N. Y., vol. 5, pt. 1, 1885, p. 326, pls. 47 and 93.

This species is common throughout the section, except where the shales are calcareous, as in the Encrinal bed, Zone D and Zone G. The variations in form are not progressive. It is not uncommon at Livonia, but was not found above the Marcellus shale at Eighteenmile Creek. 
115. Nuculites oblongatus Conrad.

Pal. N. Y., vol. 5, pt. 1, 1885, p. 324, pl. 47.

What has been said regarding the distribution of $N$. triqueter in the Cayuga Lake section is true of $N$. oblongatus. The conditions which were favorable to one were favorable to the other.

At Eighteenmile Creek it is rare in the only zone in which it occurs.

$$
\begin{aligned}
& \text { Family NUCULID A. Adams. } \\
& \text { Genus NUCULA Lamarck. }
\end{aligned}
$$

116. Nucula varicosa Hall.

Pal. N. Y., vol. 5, pt. 1, 1885, p. 319, pls. 46 and 93.

This is a very variable species, the extremes of which are often difficult to classify. It is one of the rarer nuculas.

\section{Nucula randalli Hall.}

Pal. N. Y., vol. 5, pt. 1, 1885, p. 315, pls. 45 and 93.

A small Nucula from Zone I was referred doubtfully to this species.

\section{Nucula lirata Conrad.}

Pal. N. Y., vol. 5, pt. 1, 1885, p. 316, pls. 45 and 93.

This is a common species in the Upper but is not often found in the Lower Hamilton in this section. It is reported from two zones in the Upper Hamilton at Livonia. It does not occur at Eighteenmile Creek.

119. Nucula bellistriata Conrad.

Pal. N. Y., vol. 5, pt. 1, 1885, p. 318, pl. 46.

This species is so closely related to $N$. varicosa that in some cases it is difficult to distinguish between them. It is not uncommon between Zone $\mathrm{D}$ and the Tully limestone, but is never abundant.

120. Nacula corbuliformis Hall.

Pal. N. Y., vol. 5, pt. 1, 1885, p. 319, pl. 46.

This is more common and has a greater vertical distribution than any other Nucula in the section. It is found throughout the Marcellus and Hamilton shales along Cayuga Lake. Unlike the Brachiopoda, it is present in almost every zone except those which are very calcareous, as the Encrinal, and, although it is never exceptionally abundant in the aggregate, the number of individuals is very great. 
Family LEDID $\mathbb{E}$ Adams.

Genus IHEDA Schumacher.

121. Leda rostellata Conrad.

Pal. N. Y., vol. 5, pt. 1, 1885, p. 330, pl. 47.

This species is common in the Stropheodonta-Coralline zone, but is rare elsewhere in the section. It was not found in the Marcellus shales or Zone C. It is not reported from Livonia or Eighteenmile Creek.

122. Leda brevirostris Hall.

Pal. N. Y., vol. 5, pt. 1, 1885, p. 329, pl. 47.

Specimens from Zone $\mathrm{Y}$ were referred to this species.

Genus PAI,AEONEILO Hall.

123. Palæoneilo constricta Conrad.

Pal. N. Y., vol. 5, pt: 1, 1885, p. 333, pls. 48 and 51.

$P$. constricta is a common and sometimes an almost abundant species throughout the greater portion of the section above Zone $D$. It was also found in the upper part of Zone C. Its greatest abundance is in Zone T.

124. Palæoneilo emarginata Conrad.

Pal. N. Y., vol. 5, pt. 1, 1885, p. 338, pl. 50.

This strongly marked species is common in Zone $W$, in the lower part of Zone $\mathrm{T}$, and in Zone $\mathrm{I}$; elsewhere in the section it is very rare.

125. Palæoneilo plana Hall.

Pal. N. Y., vol. 5, pt. 1, 1885, p. 334, pl. 48.

This species was not found below Zone $R$. It is quite common in Zone $\mathrm{W}$ and in the upper part of Zone $\mathrm{T}$.

126. Palæoneilo maxima Conrad.

Pal. N. Y., vol. 5, pt. 1, 1885, p. 335, pl. 48.

A single specimen from Zone $Y$ was referred to this species. It measured $34 \mathrm{~mm}$. in length by $19 \mathrm{~mm}$. in height.

127. Palæoneilo muta Hall:

Pal. N. Y., vol. 5, pt. 1, 1885, p. 337, pl. 49.

This species was found only in the Upper Hamilton, and then but rarely. Three specimens measured 19,16 , and $10 \mathrm{~mm}$. in length and 11,8 , and $5 \mathrm{~mm}$. in height, respectively. 
128. Palæoneilo fecunda Hall.

Pal. N. Y., vol. 5, pt. 1, 1885, p. 336, pl. 49.

This is a rare species in this section. With the exception of a single specimen from Zone I, it is only found, and rarely, in the Upper Hamilton.

\title{
129. Palæoneilo tenuistriata Hall.
}

Pal. N. Y., vol. 5, pt. 1, 1885, p. 336, pls. 49 and 93.

This species is restricted to a narrow zone in the Upper Hamilton of which Zone $\mathrm{W}$ is the center. One specimen, which retains a portion of the shell, shows radiating lines apparently due to the original color of the shell. Other specimens show faint radiating lines.

\section{Family PARALLELODONTID A Dall. Genus PARALLFI_ODON Meek.}

130. Parallelodon hamiltoniæ Hall.

(Macrodon hamiltonice) Pal. N. Y., vol. 5, pt. 1, 1885, p. 349, pl. 51.

This species is quite common from Zone $\mathrm{D}$ to the Tully limestone. It was found in Zones $B$ and $C$.

(P) Genus SPHENOTUS Hall.

131. Sphenotus arcæformis Hall.

Pal. N. Y., vol. 5, pt. 1, 1885 , p. 395 , pls. 65 and 66.

A small specimen of this species from Zone $K$ measured $9 \mathrm{~mm}$. in length and $4 \mathrm{~mm}$. in height. The normal size is 26 to $32 \mathrm{~mm}$. in length and 12 to $14 \mathrm{~mm}$. in height.

\section{Sphenotus cuneatus Conrad.}

Pal. N. Y., vol. 5, pt. 1, 1885, p. 396, pl. 65.

Four well-marked specimens of this species were found in Zone $G$. The specumens measured 19, 15, 16, and $6 \mathrm{~mm}$. in length and 9, 8, 8, and $4 \mathrm{~mm}$., respectively, in height.

133. Sphenotus solenoides Hall.

Pal. N. Y., vol. 5, pt. 1, 1885, p. 398, pl. 45.

This is a rare species in this section. It was found in Zones D and $\mathrm{L}$.

\section{Superfamily PTERIACEA Dall.}

\section{Family PTERINEID AE Dall.}

\author{
Genus PTERINHA Goldfuss.
}

134. Pterinea flabella Conrad.

Pal. N. Y., vol. 5, pt. 1, 1885, p. 93, pls. 14 and 15.

This species was not found in the Upper Hamilton and is very rare in the Lower Hamilton, being common in no zone. At Eighteenmile Creek it is found commonly a few feet below the Encrinal beds, but is not reported above.

Bull. 206-03-5 


\section{Family LUNULICARDIID E Fischer. \\ Genus LUNUIICARDIUM Mï̈nster.}

135. Lunulicardium fragile Hall.

Pal. N. Y., vol. 5, pt. 1, 1885, p. 434, pl. 71.

This species, with the exception of Zone D, is not uncommon between Zones $A$ and $G$. Above Zone $G$ it is rarely found. At Eighteenmile Creek it is reported from but one zone above the Marcellus shale. At Livonia it is a common fossil below the Encrinal, and is abundant in one zone of the Upper Hamilton.

136. Lunulicardium curtum Hall.

Pal. N. Y., vol. 5, pt. 1, 1885, p. 437, pl. 71.

This occurs rarely in the shales of Zone $\mathrm{C}$ and the. Marcellus.

137. Lunulicardium ornatum. Hall.

Pal. N. Y., vol. 5, pt. 1, 1885, p. 437, pl. 71.

This species was found in the upper part of Zone C.

\section{Family AMBONYCHIID $\nRightarrow$ Miller. \\ Geñus PLETHOMXTILUS Fall.}

138. Plethomytilus oviformis Conrad.

Pal. N. Y., vol. 5, pt. 1, 1885, p. 255, pls. 31 and 87.

This species was found in Zones I, F, X, and Y. The specimens measured 62,32 , and $8 \mathrm{~mm}$. in height, and 50,26 , and $6 \mathrm{~mm}$. in length. At Eighteenmile Creek it is restricted to the upper Encrinal beds.

$$
\text { Genus MXTILARCA Hall. }
$$

139. Mytilarea gibbosa Hall.

Pal. N. Y., vol. 5, pt. 1, 1885, p. 262, pls. 33 and 87.

The specimen which was referred provisionally to this species is about midway between $M$. gibbosa and $M$. simplex in form. It. measures $35 \mathrm{~mm}$. in height and $24 \mathrm{~mm}$. in length.

\section{Genus SPATHELIA Hall.}

140. Spathella typica Hall.

Pal. N. Y., vol 5, pt. 1, 1885 , p. 407 , pl. 66.

This specimen is $28 \mathrm{~mm}$. in length and 14 or $15 \mathrm{~mm}$. in height. It is slightly crushed dorso-ventrally. The concentric lines are strong, with qccasional finer concentric strị between, 


\section{Family CONOCARDIID $A$ N Neumayr.}

\section{Genus CONOCARDIUM Bronn.}

141. Conocardium normale Hall.

Pal. N. Y., vol. 5, pt. 1, 1885, p. 411, pl. 68.

A single specimen of this genus was found in Zone I. The surface markings on the posterior and the anterior expansion of the shell along the edge of the umbonal ridge can be made out.

\section{Family PTERIID A Meek.}

\section{Subgenus ACTINOPTERIA Hall.}

142. Actinopteria boydi Conrad.

Pal. N. Y., vol. 5, pt. 1, 1885, p. 113, pls. 19 and 84.

This is a rare fossil in this section. It is found occasionally in the limy shales of Zones $\mathrm{Y}$ and $\mathrm{D}$.

143. Actinopteria decussata Hall.

Pal. N. Y., vol. 5, pt. 1, 1885, p. 111, pls. 17, 18, 20, and 84 .

A few specimens of this species were found in the Upper Hamilton.

144. Actinopteria subdecussata Hall.

Pal. N. Y., vol. 5, pt. 1, 1885, p. 110, pls. 17 and 19.

A single specimen was found in Zone $\mathrm{T}$.

\section{Genus LHIOPITHRIA Hall.}

145. Leiopteria greeni Hall.

Pal. N. Y., vol. 5, pt. 1, 1885, p. 160, pls. 20 and 88 .

A single specimen of this species was found in Zone L. It neasured $38 \mathrm{~mm}$. in height and $32 \mathrm{~mm}$. along the hinge line.

\section{Leiopteria lævis Hall.}

Pal. N. Y., vol. 5, pt. 1, 1885, p. 158, pls. 17 and 20.

This species is common in the Upper Marcellus, seldom found in Zone $\mathrm{C}$, and occasionally in the shales above Zone $\mathrm{D}$.

\section{Leiopteria rafinesquii Hall.}

Pal. N. Y., vol. 5, pt. 1, 1885, p. 161, pls. 15, 20.

Specimens from Zones $\mathrm{J}$ and $\mathrm{D}$ belong to this species.

148. Leiopteria gabbi Hall.

Pal. N. Y., vol. 5, pt. 1, 1885, p. 169, pl. 88.

One individual of this species was found in Zone C. One from Zone $T$ was referred to it with some doubt. 
149. Leiopteria sayi Hall.

Pal. N. Y., vol. 5, pt. 1, 1885, p. 162, pl. 88.

This species is rather common in Zone $\mathrm{T}$, but not elsewhere in the section. It is associated with $L$. laevis.

150. Leiopteria conradi Hall.

Pal. N. Y., vol. 5, pt. 1, 1885, p. 159, pls. 20 and 88.

A number of specimens from Zones $\mathrm{D}$ and $\mathrm{T}$ were of this species. A number of intermediate forms were included.

151. Leiopteria dekayi Hall.

Pal. N. Y., vol. 5, pt. 1, 1885, p. 164, pls. 19, 20, 88.

One specimen from Zone $T$ was of this species. It was not perfect, but the obliqueness of the form, which is very characteristic of $L$. dekayi, is quite pronounced.

\section{Family MYALINID A Frech. \\ Genus MODIELLA Hall.}

152. Modiella pygmæa Conrad.

Pal. N. Y., vol. 5, pt. 1, 1885, p. 514, pl. 76.

This species is found occasionally in Zone $\mathrm{C}$ and is one of the common fossils from Zone $\mathrm{D}$ to within a foot of the Tully limestone. It reaches its greatest abundance in Zone $T$. It has very much the same habit as Nuculites oblongatus and $N$. triqueter. Although seldom common, it is almost always present except in very limy sediments.

\section{Superfamily TRIGONIACEA Bronn.}

Family TRIGONIID \& Lamarck.

$$
\text { Genus SCHIZODUS King. }
$$

153. Schizodus appressus Conrad.

Pal. N. Y., vol. 5, pt. 1, 1885, p. 449, pl. 75.

This is a rare species, but is not confined to any one zone.

154. Schizodus contractus Hall.

Pal. N. Y., vol. 5, pt. 1, p. 451, pl. 75.

Specimens of this species were found in the shales immediately under the Tully limestone and in Zone D. Between these zones it is wanting. One individual measured 4 mị. in height and $7 \mathrm{~mm}$. in length. 


\section{Superfamily PECTINACEA Reeve.}

Family PECITINID A Lamarck.

Genus AVICUIOPFCrIFAN M.Coy.

155. Aviculopecten princeps Conrad.

Pal. N. Y., vol. 5, pt. 1, 1885, p. 1, pls. 1, 5, 6, 24, and 81 .

This species is from the upper and lower portions of the Upper Hamilton. It seemed to thrive best in calcareous sediments. One right valve had markings similar to those shown in pl. 81 , fig. 16 . It was found in six zones at Eighteenmile Creek.

156. Aviculopecten fasciculatus Hall.

Pal. N. Y., vol. 5, pt. 1, 1885; p. 11, pls. 5 and 81.

One imperfect specimen from Zone D was doubtfully referred to this species.

157. Aviculopecten scabridus Hall.

Pal. N. Y., vol. 5, pt. 1, 1885, p. 7, pl. 3.

A very much distorted specimen with the characteristic surface markings was found in Zone G.

\section{Subgenus Pterineopecten Hall.}

158. Pterineopecten undosus Hall.

Pal. N. Y., vol. 5, pt. 1, 1885, p. 72, pls. 2 and 82.

This species is restricted to the Upper Hamilton and the upper: 50 feet of the Iower Hamilton. It is nowhere common, and varies greatly in shape and surface markings.

159. Pterineopecten vertumnus Hall.

Pal. N. Y., vol. 5, pt. 1, 1885, p. 71, pls. 5 and 83.

This species is found in three zones, only one specimen being found in each.

160. Pterineopecten intermedius Hall.

Pal. N. Y., vol. 5, pt. 1, 1885, p. 68, pls. 17 and 83.

This species is slightly commoner than the preceding species of Pterineopecten, and is found in a number of zones from Zone $\mathrm{D}$ to the Tully.

161. Pterineopecten hermes Hall.

Pal. N. Y., vol. 5, pt. 1, 1885, p. 64, pl. 17.

This is a well-marked but variable species, and when poorly preserved often resembles $P$. intermedius. 


\title{
Subgenus LYRIOPECTEN Hall.
}

162. Lyriopecten orbiculatus Hall.

Pal. N. Y., vol. 5, pt. 1, 1885, p. 42, pls. 4 and 82.

A specimen from Zone D was referred with considerable certainty to this genus and species.

\section{Superfamily: MYTILACEA Ferussac.}

Family MODIOLOPSID $A$ E Fischer.

\author{
Genus MODIOMORPHA Fall.
}

163. Modiomorpha subalata Conrad.

Pal. N. Y., vol. 5, pt. 1, 1885, p. 283, pls. 35 and 39.

This species is not uncommon in Zones $\mathrm{J}, \mathrm{F}$, and the upper part of $\mathrm{C}$. Four specimens measured, respecticely, 19, 21, 24, and $32 \mathrm{~mm}$. in length and $11,12,15$, and $18 \mathrm{mr}$. in height. It is a common species in the Lower Hamilton at Eighteenmile Creek.

164. Modiomorpha concentrica Conrad.

Pal. N. Y., vol. 5, pt. 1, 1885, p. 275, pls. 34, 35, 36.

This is the commonest Modiomorpha at Cayuga Lake. It is distributed from Zone D to the uttermost zone in the Hamilton. It is common in Zones H, O, T, and X. At Eighteenmile Creek it is common in the Encrinal and is found occasionally in the Lower, but does not occur in the Upper Hamilton.

165. Modiomorpha mytiloides Conrad.

Pal. N. Y., vol. 5 , pt. 1, p. 277 , pls. 37 and 38 .

This species is far from being common, but is found occasionally in Zone $\mathrm{D}$ and above. It is common in three zones above the Encrinal at Tivonia, but it is not reported from Eighteenmile Creek.

166. Modiomorpha alta Conrad.

Pal. N. Y., vol. 5. pt. 1, 1885 , p. 278 , pls. 37,80 .

Two small specimens from Zone $X$ were referred to this species. A number of specimens which seem to be of a new species have been placed in this 'species. The measurements of these were $25,18,15$, 10 , and $4 \mathrm{~mm}$. in length and $16,11,11,7$, and $5 \mathrm{~mm}$. in height.

\section{Genus GONIOPHORA Phillips.}

167. Goniophora hamiltonensis Hall.

Pal. N.Y., vol. 5, pt. 1, 1885, p. 296, pl. 43.

This species is found rarely in eight zones, commencing with the first Terebratula zone (D), to the Tully limestone. 
168. Goniophora truncata Hall.

Pal. N. Y., vol. 5, pt. 1, 1885, p. 298, pls. 42 and 44.

This well-marked species was found in Zones S and Y. Only one specimen was found in each zone and both were badly crushed.

169. Goniophora rugosa Conrad.

Pal. N. Y., vol. 5, pt. 1, 1885, p. 297 , pls. 42 and 43.

A few specimens of this species were found between Zone $D$ and the Tully limestone. Two specimens measured 40 and $45 \mathrm{~mm}$. in - length and 26 and $28 \mathrm{~mm}$. in height, respectively.

170. Goniophora glaucus Hall.

Pal. N. Y., vol. 5, pt. 1, 1885, p. 299, pls. 43 and 44.

A single badly crushed specimen from Zone $\mathrm{Y}$ was referred to this species with doubt.

\section{Order ANOMALODESMACEA Dall.}

\section{Superfamily ANATINACEA.Dall.}

Family PHOLADEJI.ID $A$ Miller.

Genus PHOIADHILA Hall.

171. Pholadella radiata Conrad.

Pal. N. Y., vol. 5, pt. 1, 1885, p. 469, pls. 78 and 96.

This species was not found in the Marcellus shales nor in Zone C, but is scattered throughout the remainder of the section. It occurs frequently in the upper shales of the Lower Hamilton and is almost abundant in Zone $\mathrm{O}$.

Three specimens measured 25,7 and $5 \mathrm{~mm}$. in length and 13,4 , and $2 \mathrm{~mm}$. in height, respectively.

172. Pholadella parallela Hall.

Pal. N. Y., vol. 5, pt. 1, 1885, p. 470; pl. 78.

This well-marked species was found in Zone $T$. It is rare in this zone and was not obtained elsewhere in the section.

Genus CIMITARIA Hall.

173. Cimitaria corrugata Conrad.

Pal. N. Y., vol. 5, pt. 1, 1885, p. 465, pl. 77.

This species was found in Zones $Y$ and $H$, but was not seen elsewhere in the section. 
174. Cimitaria elongata Conrad.

Pal. N. Y., vol. 5, pt. 1, 1885 , p. 466 , pl. $7 \dot{7}$.

Two specimens of this species were obtained from the Encrinal band at King Ferry.

\title{
Order TELEODESMACEA Dall.
}

\section{Superfamily CYPRICARDIACEA Dall.}

\author{
Family PLEUROPHORID A Dall. \\ Genus CYPRICARDFILA Hall.
}

175. Cypricardella bellistriata Conrad.

(Microdon bellistriatus) Pal. N. Y., vol. 5, pt. 1, 1885, p. 308, pls. 42, 73, 74.

This species is common in the upper part of the Upper Hamilton and in the upper portion of the Lower Hamilton; in the latter it is almost abundant. Aside from these two zones the species is quite rare in this section.

At Eighteenmile Creek it was not found above the Encrinal and, with the exception of one zone at the base of the Hamilton, is very rare throughout the section. One very large specimen from the Encrinal bed on Paines Creek measured $60 \mathrm{~mm}$. in length and 38 $\mathrm{mm}$. in height.

\section{Genus CYPRICARDINIA Hall.}

176. Cypricardinia indenta Conrad.

Pal. N. Y., vol. 5, pt. 1, 1885, p. 485, pls. 79 and 96.

This species is common in two zones, in Zone $\mathrm{X}$ and the middle third of Zone D.

Specimens measured 14, 9 , and $7 \mathrm{~mm}$. in length and 8,5 , and $4 \mathrm{~mm}$. in height, respectively. It is a Lower Hamilton fossil at Eighteenmile Creek.

\section{Superfamily LUCINACEA Anton.}

Family LUCINID $\not$ Fleming. .

Genus PARACYCIAS Hall.

177. Paracyclas tenuis Hall.

Pal. N. Y., vol. 5, pt. 1, 1885, p. 443, pls. 72 and 95.

This species is rather common in three zones of the Upper and in one zone of the upper part of the Lower Hamilton. It varies greatly in size and in the strength of its concentric striæ, but is readily distinguished from the other species of this genus. It is not reported from Eighteenmile Creek or Livonia. 
178. Paracyclas lirata Conrad.

Pal. N. Y., vol. 5, pt. 1, 1885, p. 441, pls. 72 and 95.

Only two small valves of this species were found. They measured about $7 \frac{1}{2} \mathrm{~mm}$. in height by $8 \mathrm{~mm}$. in length.

\section{Class GASTEROPODA.}

The Gasteropoda were not found to be of much value in this faunal study. They are never common, but are found occasionally in almost all of the zones.

\section{Subclass STREPTONEURA Spengel. Order ASPIDOBRANCHIA Schweigger. Suborder RHIPIDOGLOSSA Troschel. Family PLEUROTOMARIID $A$ d'Orbigny. Genus PIfUROTÓMARIA de France.}

179. Pleurotomaria itys Hall.

Pal. N. Y., vol. 5, pt. 2, 1879, p. 76, pl. 20.

As with the other species of the genus, $P$. itys is not common in nor charactistic of any zone. It occurs throughout the section. At Eighteenmile Creek it is found only at the base of the Hamilton.

180. Pleurotomaria capillaria Conrad.

Pal. N. Y., vol. 5, pt. 2, 1879, p. 77, pl. 20.

It is often difficult to distinguish the extremes of this species from the above unless the specimens are well preserved. Quite generally distributed throughout the section. Confined to the base of the Hamilton at Eighteenmile Creek.

181. Pleurotomaria trilix Hall.

Pal. N. Y., vol..5, pt. 2, 1879, p. 79, pl. 21 .

Found rarely in the Upper Hamilton at Cayuga Iake.

182. Pleurotomaria sulcomarginata Conrad.

Pal. N. Y., vol. 5, pt. 2, 1879, p. 69, pl. 19.

Two specimens of this species were obtained from the upper part of the Upper Hamilton, Zones $\mathrm{W}$ and $\mathrm{T}$.

183. Plearotomaria rotalia Hall.

Pal. N. Y., vol. 5, pt. 2, 1879, p. 71, pl. 19.

Two specimens from Zone ' $\mathrm{T}$ ' were of this species. 
184. Pleurotomaria rugulata Hall.

Pal. N. Y., vol. 5, pt. 2, 1879, p. 75, pl. 20.

This species is met with occasionally in Zone C, in the Marcellus shales, and in Zone D. The specimens are all very much crushed or in the form of molds, and the surface markings are indistinct.

\section{Family BELLEROPHON'TID AE McCoy. \\ Genus BHLIFROPHON de Montfort.}

185. Bellerophon patulus Hall.

Pal. N. Y., vol. 5, pt. 2, 1879, p. 100, pls. 22 and 24.

This species is not uncommon in Zones $\mathrm{X}$ and $\mathrm{N}$; elsewhere it is rare. It was not found below Zone C.. The specimens obtained were of the usual size, but badly crushed.

186. Bellerophon leda Hall.

Pal. N. Y., vol. 5, pt. 2, 1879, p. 110, pl. 23.

This is the most common Bellerophon in the section. It is almost common in some of the thin layers of Zone C. It is common in the lower portion of the Iower Hamilton at Eighteenmile Creek.

187. Bellerophon lyra.

Pal. N. Y., vol. 5, pt. 2, 1879, p. 113, pl. 23.

Only a few specimens of this species were found in the section.

188. Bellerophon crenistria Hall.

Pal. N. Y., vol. 5, pt. 2, 1879, p. 116, pl. 25.

A few specimens of this species were obtained in six zones of the Upper and Lower Hamilton.

\section{Genus CYRTOLITES Conrad.}

189. Cyrtolites mitella Hall.

Pal. N. Y., vol. 5, pt. 2, 1879, p. 123, pl. 25.

Only a few specimens of this species were obtained. None were found lower than Zone D.

Family EUOMPHALID $A$ de Koninck.

Genus HUOMPPALUS Sowerby.

190. Enomphalus sp.

Pal. N. Y., vol. 5, pt. 2, 1879, p. 54.

A single crushed specimen from Zone Owas referred to this genus. The specific characters could not be made out. 
Order CTENOBRANCHIATA Schweigger.

\title{
Suborder PLATYPODA.
}

\section{Superfamily TANIOGLOSSA Bouvier.}

Family CAPULID \& Cuvier.

Genus PLATYCFRAS Conrad.

191. Platyceras conicum Hall.

Pal. N. Y., vol. 5, pt. 2, 1879, p. 3, pl. 1.

A single large specimen was found in the Encrinal beds.

- 192. Platyceras erectum Hall

Pal. N. Y., vol. 5, pt. 2, 1879, p. 5, pl. 2.

This gastropod was found most commonly in the upper portion of the Encrinal and in the limestone of Zone $\mathrm{Y}$. Elsewhere it is rare.

193. Platyceras bucculentum Hall.

Pal. N. Y., vol. 5, pt. 2, 1879, p. 10, pl. 3.

Typical specimens of this species were found in Zones Y and S.

194. Platyceras carinatum Hall.

Pal. N. Y., vol. 5, pt. 2, 1879, p. 5, pl. 2.

Specimens having the characteristic shape of this speries were found in Zones $\mathrm{W}$ and $\mathrm{Y}$.

\section{Genus PIATYOSTOMA Conrad.}

195. Platyostoma lineata Conrad.

Pal. N. Y., vol. 5, pt. 2, 1879, p. 21, pl. 10.

This species was found in a number of zones, but was not common in any. It possesses, in all cases, the characteristic surface markings.

196. Platyostoma varians Hall.

(Strophostylus) Pal. N. Y., vol. 5, pt. 2, 1879, p. 31, pl. 11.

A large specimen from Zone $J$ and eight smaller ones from Zone $C$ were referred to this species with some doubt. The larger specimen is typical; the smaller ones are small, and may be of a new species.

\section{Superfamily GYMNOGLOSSA.}

Family PYRAMIDELLID AE Gray.

\author{
Genus LOXONE:MA Phillips.
}

197. Loxonema hamiltoniæ Hall.

Pal. N. Y., vol. 5, pt. 2, 1879, p. 45, pl. 13.

This species occurs throughout the entire section. It is often difficult to distinguish it from $L$. delphicola when the specimens are imperfect. At Eighteenmile Creek this species and $L$. delphicola are restricted to the Upper Marcellus shales. 
198. Loxonema delphicola Hall.

Pal. N. Y., vol. 5, pt. 2, 1879, p. 47, pls. 13 and 14.

This species is frequently met with in the section above Zone D. It is commoner than $L$. hamiltonice. Very often the shell is surrounded by a "smooth, polished shale (slickensides)," as is figured by Hall in figs. 24 and 25 of the above report.

\title{
Superfamily PTENOGLOSSA Gray.
}

Family SCALARIID AE Broderip.

Genus CALLONEMA Hall.

199. Callonema imitator Hall and Whitfield.

Pal. N. Y., vol. 5, pt. 2, 1879, p. 53, pl. 14.

One specimen, $50 \mathrm{~mm}$. in diameter, with the surface marked by strong elevated striae gently curving backward and increasing in strength from the apex to the last volution, was found in Zone $\mathrm{N}$. The coil is rather loose.

\section{Order OPISTHOBRANCHIA Milne-Edwards.}

\section{Suborder PTEROPODA Cuvier.}

Family CAVOLIINDAE Fischer.

\author{
Subgenus STYLIOLA Lesueur.
}

200. Styliola fissurella Hall.

Pal. N, Y., vol. 5, pt. 2, 1879, p. 178, pl. 31A. •

It will be noticed in the table of species that $S$. fissurella is very rare, almost wanting, in the Upper Hamilton; that between Zone D and the Encrinal, with the exception of the fine shales of Zone E, it is also very rare, and that in the fine shales of Zone $\mathrm{C}$ and in the Marcellus shales it is very common. In the lower portion of the Marcellus shales the Styliola is beautifully preserved in pyrite. It is very abundant in certain layers in the Marcellus shales. At Eighteenmile Creek it is very common in a number of zones of the Lower and is fairly common in the uppermost zone of the Upper Hamilton.

\section{Suborder CONUILARIDA Miller and Gurley.}

\section{Family TENTACULITID AE Walcott.}

\section{Genus TENTACUIITES Schlotheim.}

\section{Tentaculites bellulus Hall.}

Pal. N. Y., vol. 5, pt. 2, 1879 , p. 169 , pls. 31 and 31A.

A specimen of this species was obtained from Zone X. In Zone A there are great numbers of 'I'entaculites, but in such a poor state of preservation that it is impossible to make a specific identification. 


\section{Family TORELLELLID $A$ E Holm. Genus COLFOLUS Hall.}

202. Coleolus tenuicinctum Hall.

Pal. N. Y., vol. 5, pt. 2, 1879, p. 185, pls. 32 and 32A.

A number: of very good specimens of this species were found in various parts of the section.

\section{Family HYOLITHID AE Nicholson. \\ Genus HYOLITHES Fichwald. \\ 203. Hyolithes aclis Hall.}

Pal. N. Y., vol. 5, pt. 2, 1879 , p. 197 , pls. 32 and 32 A.

Although this is a rare species at Cayuga Lake, in the aggregate the number found is quite large. The variations consist in the relative difference in length, width, and thickness. The measurements are $30,30,25 \mathrm{~mm}$. in length and 9,11 , and $12 \mathrm{~mm}$. in width. Two well-preserved opercula were found.

204. Hyolithes striatus Hall.

Pal. N. Y., vol. 5, pt. 2, 1879, p. 199, pl. 32.

A specimen with well-marked longitudinal lines was found in Zone $T$.

Genus CONUIA RIA Miller.

205. Conularia undulata Conrad.

Pal. N. Y., vol. 5, pt. 2, 1879, p. 208, pls. 333 and 34A.

A fragment of a large specimen of this species with very strong surface markings was found in Zone D. A fragment of a smaller individual was taken from Zone I.

\section{Class CEPHALOPODA.}

\section{Subclass TETRABRANCHIATA Owen. \\ Order NAU'TILOIDEA.}

\section{Suborder ORTHOCHOANITES Hyatt.}

Family ORTHOCERATID $A$.

Genus ORTHOCHRAS Breynius

206. Orthoceras crotalum Hail.

Pal. N. Y., vol. 5, pt. 2, 1879 , p. 296, pls. 42, 82, and 93.

This fossil is found occasionally throughout the section above Zone D. The test is often denuded, making the identification in some, cases uncertain. 
207. Orthoceras cælamen Hall.

Pal. N. Y., vol. 5, pt. 2, 1879, p. 298, pls. 42, 43, 82, 113.

A few specimens with the characteristic surface marking were obtained from the Upper Hamilton shales.

208. Orthoceras nuntium Hall.

Pal. N. Y., vol. 5, pt. 2, 1879, p. 299, pls. 43 and 82.

This is a rare fossil in this section. Two specirnens were found in the Upper Hamilton.

209. Orthoceras subulatum Hall.

Pal. N. Y., vol. 5, pt. 2, 1879, p. 283, pls. 38, 84, 86 .

This species of Orthoceras is not uncommon along Cayuga Lake. A large number of distorted specimens of this genus wero referred here with some doubt. One specimen showed the surface markings.

210. Orthoceras constrictum Vanuxem.

Pal..N. Y., vol..5, pt. 2, 1879, p. 288, pls. 84,85 .

This is a rather rare species in this section, and is not reported west of Cayuga Lake.

211. Orthoceras exile Hall.

Pal. N. Y., vol. 5, pt. 2, 1879, p. 290, pls. 39, 84, 85.

A few specimens were doubtfully placed in this species.

212. Orthoceras marcellense Vanuxem.

Pal. N. Y., vol. 5, pt. 2, 1879, p. 278, pls. 38, 83, and 113.

A specimen from the Marcellus seems to be of this species.

213. Orthoceras, sp. undet.

This genus, as a whole, is common between Zones $\mathrm{B}$ and $\mathrm{F}$, inclusive, and in Zone T. Elsewhere in the section this genus was rare.

Family NAUTILID AE.

Genus NAUTILUS Breyn.

214. Nautilus liratus juvenis Hall.

Pal. N. Y., vol. 5, pt. 2, 1879, p. 411, pl. 56.

James Hall describes this variety of $N$. liratus from an imperfect specimen and states that the determination is quite unsatisfactory. Two fairly well-preserved specimens from the hard shales of the upper Marcellus are certainly distinct from $N$. liratus and answer to the description of $N$. liratus juvenis. The difference between these specimens and $N$. liratus, however, seems to be specific rather than varietal.

215. Nautilus, fragments.

A number of fragments of Nautilus found in various parts of the section were too imperfect for specific identification. 
Suborder CYRTOCHOANITES Hyatt.

Family PHRAGMOCERATID $A$.

Genus GOMPHOCERAS Sowerby.

216. Gomphoceras, sp.

Pal. N. Y., vol. 5, pt. 2, 1879, p. 318.

A single crushed specimen of this genus was found in Zone C. The markings were obliterated to such an extent that it was impossible to make a specific identification.

\title{
Order AMMONOIDEA. \\ Suborder EURYCAMPYLI Hyatt. \\ Family GLYPHIOCERATID $\approx$. \\ Genus GONIATIIHS de Haan. \\ 217. Goniatites discoideus Hall.
}

Pal. N. Y., vol. 5, pt. 2, 1879, p. 441, pls. 71, 74.

Casts of the test showing the fine, closely arranged striæ, " raised at intervals in fascicles," were commoner than those showing the septa. This species was fairly common in Zone T. In Zone I a number of imperfect specimens which were either of this species or of $G$. uniangularis were quite frequently found. Elsewhere in the section they are very rare.

218. Goniatites uniangularis Conrad.

Pal. N. Y., vol. 5, pt. 2, 1879, p. 444, pls. 71, 74.

This species was very rare, but several well-preserved specimens were found. One almost ${ }^{\circ}$ perfect small specimen from the lower shales of Zone $\mathrm{C}$ measured $15 \mathrm{~mm}$. in diameter in the widest part. A large specimen measured $4.5 \mathrm{~mm}$. in diameter.

\section{Subkingdom ARTHROPODA. Clàss CRUSTACEA.}

\author{
Subclass TRILOBITA:
}

Order OPISTHOPARIA Beecher.

Family PRÖETID A Barrande.

Genus PRÖFrrUS Steininger.

219. Pröetus rowi Green.

Pal. N. Y., vol. 7, 1888, p. 119, pls. 21 and 23.

A portion of the cephalon with a crushed glabella and a perfect genal spine was referred, with some doubt, to this species, 
220. Pröetus microgemma Hall.

Pal. N. Y., vol. 7, 1888, p. 109, pl. 22.

An imperfect pygidium was referred with considerable certainty to this species.

221. Pröetus macrocephalus Hall.

Pal. N. Y., vol. 7, 1888, p. 116, pls. 21 and 23.

A pygidium and thorax were found in Zone $\mathrm{Y}$ and a glabella in the Encrinal bed. The surface markings are quite plain.

\section{Genus HOMATONOTUS Kö̈nig.}

222. Homalonotus dekayi Green.

Pal. N. Y., vol. 7, 1888, p. 7, pls. 2, 3, 4, 5.

This is quite a common fossil in the upper portion of the Encrinal band. A fragment of a pygidium was found in Zone $Y$ and a portion of a cephalon in Zone D. At Eighteenmile Creek it is reported from the lower portion of the Lower Hamilton. In Kashong Creek it occurs rarely in the Upper Hamilton.

\section{Order PROPARIA Beecher.}

\section{Family PHACOPID $\mathbb{E}$ Salter. \\ Genus PAACOPS Fimmrich.}

223. Phacops rana Green.

Pal. N. Y., vol. 7, 1888, p. 19, pls. 7, 8, 8A.

This is a common and sometimes an abundant species in this section. Above the Encrinal it occurs in almost every zone. Occasionally a complete specimen was found. It is usually associated with $D$. boothi and $A$. umbonata.

\section{Phacops cristata var. pipa Hall.}

Pal. N. Y., vol. 7, 1888, p. 18, pl. 8.

A specimen of this variety was found in Zone A.

Genus DALMANITES Fmmrich.

225. Dalmanites boothi Green.

Pal. N. Y., vol. 7, 1888, p. 42, pls. 16, 16A.

This species was found in the lowest portion of Zone C. It is common throughout the section from Zone D to the Tully, especially above the Encrinal.

At Eighteenmile Creek it is commonest below the Encrinal, while at Cayuga Lake the opposite is true.

226. Dalmanites boothi var. calliteles Green.

Pal. N. Y., vol. 7, 1888, p. 45, pls. 16, 16A.

A few specimens of this variety were found in the upper portion of the Upper Hamilton. 
Subclass EUCRUSTACEA Kingsley.

Superorder MALACOSTRACA Latreille.

Order PHYLLOCARIDA Packard.

Suborder Ceratiocarina Clarke.

Family ECHINOCARID $A$, Clarke.

Genus ECHINOCARIS Whitield.

227. Echinocaris punctata Hall.

Pal. N. Y., vol. 7, 1888, p. 166, pls. 27, 28, 29.

Five specimens of this species were found in the Cayuga Lake sec- . tion, one in the Upper and four in the Lower Hamilton above Zone D.

Genus TROPIDOCARIS Beecher.

228. Tropidocaris hamiltoniæ Hall.

Pal. N. Y., vol. 7, 1888, pl.' 30.

A right valve of this species was found in Zone $O$. It measured $10 \mathrm{~mm}$. in length.

\section{Suborder FHINOCARINA Clarke. \\ Family RHINOCARDID AE Clarke. \\ Genus RHINOCARIS Clarke.}

229. Rhinocaris sp.

Pal. N. Y., vol. 7, 1888, p. lviii, pl. 31.

Two specimens of this genus, one with both valves, the other with one valve of the carapace were found in the shale of Zone $\mathrm{C}$ along Dean Creek. The preservation was too imperfect to permit of specific identification.

Genus MFSO'PHYRA Hall and Clapke.

230. Mesothyra oceani Hall.

Pal. N. Y., vol. 7, 1888, p. 187, pls. 33 and 34.

Two specimens of this genus were referred doubtully to this species. Neither specimen is perfect enough to warrant a specific identification. The length of the carapace is $20 \mathrm{~mm}$. and $45 \mathrm{~mm}$., respectively.

\section{Superorder OSTRACODA Latreille.}

The various species and genera of this superorder seem to have been adapted to the same conditions of environment during the Hamilton stage. They are common in the fine shale of Zones B, C, and $\mathrm{E}$.

Bull. 206-03-6 


\section{PLANT $A$.}

Genus LEPIDODENDFON Sternberg.

232. Lepidodendron gaspianum Dawson.

Quar. Jour. Geol. Soc., 1859, vol. 15், p. 484.

A specimen of this plant with distinct imprints of the leaves was found in Zone $\mathrm{C}$.

Thanks is due Professor Penhallow for the identification.

233. Plant fragments.

Plants, usually in a poor state of preservation, were scattered throughout the section. Within a foot or two of the Tully limestone plant fragments were especially well preserved and abundant. Genus TAONURUS.

234. Taonurus sp.? Fischer-Ooster.

This fucoid was very abundant in the upper portions of the Upper and Lower Hamilton. 


\title{
CHAPTER V.
}

\section{COMPARISON OF THE CAYUGA LAKE SECTION WITH OTHER SECTIONS OF THE HAMILTON FORMATION.}

\author{
BASAL LIMESTONE.
}

The Basal limestones of Ontario County are described by J. M. Clarke, as follows: $a$

Within 10 feet of the top of the Marcellus shales, where the rocks still retain their characteristic color and diagnostic fossils, appear Spirifer mucronatus and Ambocoelia umbonata of the Hamilton fauna, such Hamilton species increasing in number and the rocks becoming less and less bituminous until at the top of 10 feet the bituminous character has disappeared and with it the Marcellus fauna. Overlying is a series of strata of limestone more or less impure and persisting throughout the county east and west.

Farther east the same strata become more shaly and lose many of the fossils of the richer western outcrop. Dr. D. F. Lincoln ${ }^{b}$ accepted. the term "Basal Hamilton," proposed by J. M. Clarke, and the description of Hall in the report of the Fourth District c- "a compact calcareous blue shale passing into an impure limestone." He says that it retains this character (of a coral reef) to some extent in Seneca County, displaying scattered fragments of Heliophyllum, Favosites, and other large corals which do not belong elsewhere in the region.

From the description given above and from its position in the section (see map Pl. I) it seems certain that the compact calcareous shales of Zone D should be correlated with the Basal Hamilton of Ontario and Seneca counties. ${ }^{d}$ There is, however, considerable difference in the faunules. Although the corals are very much rarer in Zone D at Cayuga Lake compared with that stratum in the west, yet Heliophyllum is common only in this stratum in the Cayuga Lake section. This zone is characterized in Ontario County by a great, abundance of Crustacea. The development of Crustacea in Zone D is by no means remarkable, only three species of trilobites being found, none of which were abundant.

aReport State Geol., New York, 1885.

b Ibid., 1894.

$c 1843$.

$a$ Since the above was written the author revisited the localities on Seneca Lake. There is no doubt as to the correctness of the correlation. 
A comparison of the Basal Hamilton of Ontario County, Seneca County, and Zone D of Cayuga Iake shows a decrease in the amount of calcareous matter and in corals from west to east. It is probable that the region along Cayuga Lake was the edge of the reef, if such it can be called, and that the conditions were such that most of the species of corals and Crustacea which flourished so well in the west were represented in the Cayuga Lake region by an abundant brachipod and pelecyopod fauna, with here and there a large Heliophyllum halli and a colony of Syringopora.

This impure limestone layer, the Basal Hamilton, is, next to the Encrinal beds, the most persistent stratum in the New York Hamilton, extending as it does for more than 40 miles from east to west.

I. P. Bishop, in the Geology of Erie County, mentions ${ }^{a}$ a calcareous stratum in that county which he correlated provisionally with the Basal limestone of Clarke. The evidence for this correlation is so unsatisfactory that it must be disregarded.

\section{ENCRINAL BEDS.}

In comparing the faunules of the Encrinal beds with that of Eighteenmile Creek, it was found that of 8 lamellibranchs of the Eighteenmile Creek Encrinal 4 are found in the Encrinal of the Cayuga Lake section, 2 are extremely rare, and 2 have been found nowhere in this section. Of the 35 brachiopods, 13 were not found in the Encrinal of Cayuga Lake. But of that number 4 have not been found elsewhere in the section and 4 are extremely rare. Vitulina pustulosa, Centronella impressa, Meristella haskinsi, and Heliophyllum confluens are restricted to the Encrinal at Eighteenmile Creek. With the exception of $V$. pustulosa and $M$. haskinsi, which was found in the Encrinal and Zone D, these species are restricted to the Encrinal at Cayuga Lake. Grabau ${ }^{b}$ finds the Encrinal at Eighteenmile Creek to be the equivalent of that at Iivonia. The comparison of the fossils from that stratum in the two places brings out the fact that only one species given in the Livonia list is wanting in the limestone at Eighteenmile Creek. James Hallc considered the Encrinal as a "persistent mass holding only one position in the giroup and continuous as far as Lake Erie. It is a convenient point of reference." It is $1 \frac{1}{2}$ feet thick at Lake Erie, 2 feet at Livonia, 3 feet in Yates County, and $1 \frac{1}{2}$ feet in Cayuga County.

Prof. C. S. Prosser, ${ }^{d}$ in discussing Professor White's correlation of a zone in eastern Pennsylvania which is as rich in corals and crinoids as the Tully, shows by the fossil content that the Genesee shales of White are Hamilton shales. The so-called Tully does not contain any

" Report State Geol. New York, 1895.

$b$ Report State Geol. New York, 1898.

c Report Fourth District New York, 1843.

d Bull. U. S. Geol. Survey No. 120, 1894, p. 74. 
characteristic Tully fossils, but, contains only Hamilton species. He says:

If a correlation of this zone with one of central and western New York were attempted, I would suggest the Encrinal limestone separating the fossiliferous argillaceous Ludlowville and Moscow shales; As the Pennsylvania horizon may be represented by any one of the several coral horizons in the Hamilton of New York or by an entirely different one, such a correlation of this zone is very hazardons without carefui comparison of the species and stratigraphy.

On the east shore of Skaneateles Lake, $2 \frac{1}{2}$ miles from the head of the lake, is a bed of cyathophylloid and other genera of corals 5 feet thick, which are described by Luther. ${ }^{a}$ Luther concludes, from its position and from the fact that it "abcunds in cyathophylloid corals which characterize the Encrinal of the western counties," that it is probably the eastern extension of the Encrinal band. Since in Ontario, Seneca, and Cayuga counties the most abundant coral faunas are in the Basal Hamilton, either this coral reef at Skaneateles Lake is (1) a continuation of the stratum called the "Basal Hamiton," which is several hundred feet above the Marcellus shales in the Cayuga Lake section, or (2) the Encrinal, or (3) the union of (1) and (2), or (4) a separate stratum. With the data now at hand Luther's supposition is as probable as any other.

Since the Encrinal is found in a number of localities between Lake Cayuga and Lake Erie, of the same lithological character, in relatively the same position in the shale, with a fauna which changes little in a distance of 125 miles, it should be considered as a continuous stratum. East of Cayuga Lake the correlation of the coral zones is yet to be worked ont. However, conditions of sedimentation such as would produce a limestone stratum anywhere in the Middle Hamilton would be adapted to and contain what might be called a limestone fauna which would not differ materially from the fauna of the Encrinal; and whether this stratum were continuous or not, the same association of fossil would probably exist.

\section{GASTEROPODA.}

Gasteropoda predominate both in specific and in individual development in the lower shales of Ontario County. This is also the condition at Eighteenmile Creek, where only one gasteropod, Platyostoma lineata, is found above the Encrinal, and that but rarely in one layer. In the Cayuga Lake section Gasteropoda are not common in any portion of the section, but are about as frequently met with above as below the Encrinal. They occur, however, rather more frequently, in proportion to the Pelecypoda, and Brachiopoda, in the fine shales of Zone $\mathrm{C}$. 
USE OF TERMS "UPPER" AND "LOWER" HAMILTON FAUNA.

The data at hand-the faunules of the Cayuga Lake, Eighteenmile Creek, and Livonia sections-are sufficient to warrant some definite statement as to the propriety of the terms "an Upper Hamilton fauna" or "a Lower Hamilton fauna," used by some writers as signifying an ability to distinguish between them:

A comparison of the Cayuga Lake section with that of Eighteenmile Creek shows that the relative abundance of species and individuals in the Upper and Lower Hamilton of the two sections is reversed. At Cayuga Lake the number of species and individuals is greater above than below the Encrinal beds, while the opposite is decidedly true of the Eighteenmile Creek section.

Spirifer granulosus is a rather common fossil above and below the Encrinal at Cayuga Lake, but is restricted to the Lower Hamilton and the Encrinal at Eighteenmile Creek and to the Upper Hamilton at Livonia. Reticularia fimbriata, Tropidoleptus carinatus, and the lingulas are distributed in the three sections in the same manner as Spirifer granulosus.

Stropheodonta concava and $S$. junia are in the Lower Hamilton at Eighteenmile Creek, but are restricted to the Upper Hamilton at Cayuga Lake and Livonia.

Only two species of Brachiopoda have been found, which are restricted to the. Upper Hamilton of the three sections, exclusive of the Encrinal-Ambocolia proumbona and Spirifer marcyi. But it would not be remarkable if even these were found lower. Since these species have not been reported east of Cayuga Lake, they must of necessity have little use in stratigraphy. Ambocclia prceumbona has not been reported outside of New York State, and it may have originated in western New York after the Encrinal band was deposited.

Leiorhynchus limitare, Spirifer macrus, Anoplotheca camilla, and Strophalosia truncata are species which have not been reported above the Encrinal beds. The first is a typical Marcellus fossil (reported by Clarke. ${ }^{a}$ in a "recurrent fauna" above the "Basal limestone" in Ontario County); the second and third are typical Onondaga (Corniferous) species which have never been found above the Marcellus; only the fourth, Strophalosia truncata, is a species often found in the Hamilton. A comparison of the corals, pelecypods, and gasteropods brings the same results.

From the above it will be seen that the burden of evidence at present is against the supposition that it is possible, without the aid of stratigraphy, to distinguish between the Upper and Lower Hamilton fauna. However, the presence of Spirifer marcyi and Ambocolia prceumbona and the absence of Strophalosia truncata in a fauna would be presumptive evidence of the Upper Hamilton. 


\section{EXPLANATION OF DIAGRAM, FIG. 3.}

The data from which this diagram was constructed were obtained from the New York Geological Reports, commencing with vol. 4, 1867, Palæontology of New York, together with the Peabody Museum collections from Onondaga, Cayuga, Seneca, Genesee, and Erie * counties used in the preparation of this paper. The distances are only approximate, some noted collecting locality being usually taken as a center.

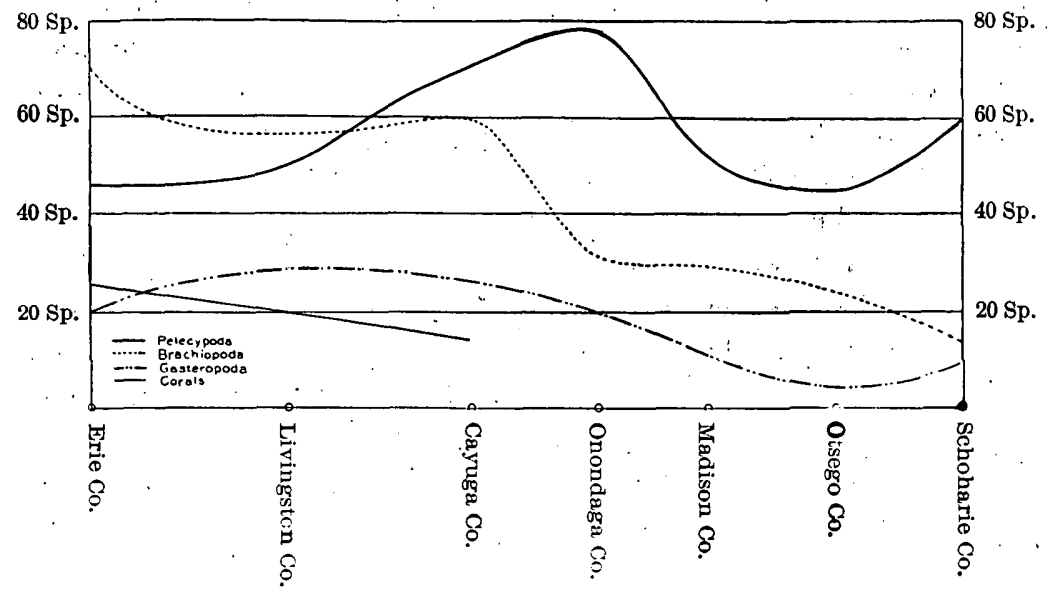

Fua. 3.-Diagram showing the distribution of fossils of the Hamilton stage throughout New York State.

The curves from Onondaga County west are probably more nearly. correct than those east, because of the exceptionally careful collections from Pompey; Cayuga Lake, Livonia, and Eighteenmile Creek. The faunal lists of Prof. C. S. Prosser ${ }^{a}$ make the collections from the extreme eastern portion of the State fairly full.

As is readily seen, the center of abundance of Pelecypoda is in Onondaga County. From that point the decrease to the west is rapid. The decrease in the number of species of. Pelecypoda in the arenaceous shales east of Onondaga County would probably be less than represented were fuller collections to be had. That the oonditions in eastern New York were much less favorable to the development of brachiopods than of pelecypods is shown by the fact that the relative abundance of brachiopods to pelecypods in Schoharie County is 13:60, while at Lake Erie the ratio is $70: 40$.

The increasing abundance of species of brachiopods from east to west is very striking and uniform. The line showing the abundance of Gasteropoda varies less from east to west than the other classes. The data concerning the corals show a uniform increase between Cayuga and Erie counties. 
Two facts should be borne in mind in the consideration of the relative abundance of fossils when studied geographically, (1) the excellent opportunities for collecting in certain localities, as central and western New York, and the greater difficulty in others, as the eastern counties of New York, and (2) the fact that often in a formation the same time elapsed during the deposition of a few feet of sediment in one place that it took for the deposition of many times that thickness in another locality in the formation. The time required for the deposition of the 67 feet of sediment at Eighteenmile Creek, the 517 feet at Livonia, the 1,100 feet at Cayugi Lake, and the great thickness of the eastern shales was the same. At any one time there may not have been a greater number of living shells in Erie County than in the central or eastern part of the State; the conditions were, however, more favorable for the development of brachiopods and corals than for pelecypods.

The change from east to west, not only in the relative number of species but in the species themselves, is spoken of by $\mathrm{Hall}^{a}$ as follows: "So great is this change that if a collection of fossils from the Hamilton formation in the counties of Albany and Schoharie be compared with a collection from the same group in Genesee and Erie counties the number of species common to both would be less than has been sometimes indicated as passing from one geological formation to another." 


\section{CHAPTER VI.}

\section{CONCLUSIONS.}

In this investigation the following conclusions have been reached:

(1) There are a number of fossil faunules in the Hamilton formation which can be quite accurately defined. A glance at the diagrams Pl.V, $A$ and $B$, and the table (Appendix) shows the distinctness with which many of these faunules are marked off. On the present sea bottom it is possible, given the conditions of bottom, depth, temperature, etc., in any region, to state with considerable certainty the composition of the faunule. The boundary line between modern faunules is sometimes distinct, but often there is such a mixture of the two faunules at the boundary that it is impossible to state where the line should be drawn. In the vertical distribution of fossil faunules the same difficulty is encountered. Shales containing a mixture of faunules are not uncommon, but. where uniform conditions prevailed for a considerable length of time a definite group.of species occurs. Occasionally the change was sudden, and the faunules are separated by a distinct line. Zone $\mathrm{D}$ is an excellent example of such a case; the shales above and below are almost barren of fossils, while Zone $D$ is very fossiliferons. Occasionally a thin layer of fine shale is seen in the midst of a fossiliferous zone, or a thin layer rich in fossils in a barren zone.

(2) The difference between the composition of different faunules of the Hamilton formation is often more marked than between faunules of the same facies belonging to different formations. A study of living faunules leads one to expect such a condition, since in a short distance bathymetrically and geographically there is often a complete change in species.

(3) Migration of the organisms which lived during the Hamilton stage was undoubtedly accomplished in the same way as at present. ${ }^{a}$ Such animals as Crustacea and Orthoceratites had considerable power of movement in the adult condition, but the common fossil animals, such as the brachiopods and pelecypods, were practically stationary when mature. The only means of migration for such classes was during the free swimming stage. During this stage they were carried abont by currents and to some extent moved by their own activity.

aSee Parker and Haswell, Text-Book of Zoology, and other Zoologies. Marine Bionomy. Grahati. 
Zoologists cite many cases of the sudden appearance of species previously unknown to certain localities which were carried there during the free swimming stage by unusual conditions. These species often live but one year, and may not be seen again for years. Drifting timber and other means enable old and young of certain species to be carried long distances. The migration of the species making up the bulk of the Hamilton faunules undoubtedly took place, for the most part, during the free swimming stage.

(4) The repetition of faunas such as are found in a section like that of Cayuga Lake shows that there was an oscillation of similar conditions. It is probable that had the conditions remained uniform during the whole of the stage only one of these faunas would have occurred. The Leiorhynchus zone is several hundred feet thick in this region. There is no objection to the supposition that such a faunule would have lived on throughout the stage had the conditions remained as they were during the deposition of that zone.

(5) An "accidental" faunule is one which has been produced in a long" period of time in a region where sedimentation has been very slight, but in which the conditions changed for short periods sufficiently to introduce a few species. In the aggregate the number of species of such a faunule may be great. A faunule of this character is very confusing, composed, as it is, of species from perhaps several faunules. It was not unusual for a thousand or more feet of sediment to be deposited in one region, while in another, during the same period of time, only a few feet were laid down. It is consequently unsafe to say, because fossils are abundant in a few inches of shale, that the conditions were necessarily exceptionally favorable for the development of that faunule. It is not impossible that hundreds or even thousands of years may have elapsed during the deposition of such a zone. The comparison of the thickness of the Hamilton formation at Cayuga Lake with that at Eighteenmile Creek showed that while 1,100 feet of shales were deposited in the Cayuga Lake region only 67 feet were deposited at Eighteenmile Creek. On the other hand, that great length of time and little sedimentation are not necessary for the formation of all fossiliferous zones is evident from the peculiar and characteristic faunules of these zones and the position of the fossils in the shale and limestone.

(6) In a section such as that of the Hamilton formation at Cayuga Lake, which represents in its formation between $1,846,150$ and $26,153,840$ years, ${ }^{\text {if }}$ the statement "natura non saltum facet" is granted, one should, with some confidence, expect to find many-at least someevidences of evolution. ... A careful examination of the fossils of all the zones, from the lowest to the highest, failed to reveal any evolutional changes, with the possible exception of Anubocolia proumbona

\footnotetext{
a The first estimate is from Dana; the serond is the maximum of Geikie. The Meso-Devoniañ. was estimated as one-third the Devonian.
} 
The species are as distinct or as variable in one portion of the section as in another. Species varied in shape, in size, and in surface markings, but these changes were not progressive. The conclusion must be that, so long as the conditions of sedimentation remain as uniform as they were in the section under consideration, the evolution of brachiopods, gastropods, and pelecypods either does not take place at all or takes place very seldom, and that it makes little difference how much time elapses so long as the conditions of environment remain unchanged.

(7) An analysis of the Hamilton faunas shows conclusively that there is little basis for the terms "an upper" and "a lower Hamiltonian fauna" unless these terms are used to signify that it is possible in isolated sections to state, from the composition of the fauna, whether the rock is above or 'below the Encrinal bed.

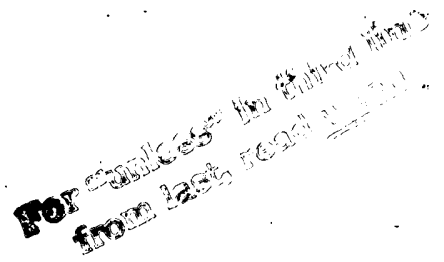




\section{CHAPTER VII.}

\section{BIBLIOGRAPHY OF LITERATURE USED IN THE PREPARATION OF THIS PAPER.}

BEECHER, C. E. Outline of a natural classification of the trilobites. Am. Jour. Sci., 4th series, vol. 3, 1897.

Larval stages of trilobites. Am. Geol., vol. 16, 1895.

- Development of the brachiopod. Am. Jour. Sci., 3d series, vol. 44, 1892.

Bishop, I. P. The structural and economic geology of Erie County, N. Y. Fifteenth Ann. Rept. State Geol. New York, 1898.

Calvin, Samuel. Hamilton faunas of Thedford, Ontario. Am. Geol., vol. 1. 1888. Clarke, J. M. A brief outline of the geological succession in Ontario County, N. Y. Ann. Rept. State Geol. New York, 1884.

The succession of the fossil faunas in the section of the Livonia salt shaft. Thirteenth Ann. Rept. State Geol. New York, 1894.

A list of species constituting the known fauna and flora of the Marcellus epoch in New York. Eighth Ann. Rept. State Geol. New York, 1889.

Conrad, T. A. First annual report on the geological survey of the third district of New York, 1837.

Second, third, fourth, and fifth annual reports on the paleontology of the State of New York, 1839-1841.

Eastman, C. R. Translation of Zittel's text-book of Paleontology. 1900.

Eaton, Amos. Index to the geology of the Northern States, 1820.

A geological and agricultural survey of the district adjoining the Erie Canal, 1824.

Observations on coal formations, etc. Am. Jour. Sci., 1st series, vol. 19, 1831.

GILBERT, G. K. The work of the International Congress of Geologists. (Vicepresident's address (Sec. E) A. A. A. S., 1887.)

GrabaU, A. W. The faunas of the Hamilton group of Eighteenmile Creek and vicinity in western New York. Sixteenth Ann. Rept. State Geol. New York, 1898.

Moniloporidæ, a new family of Paleozoic corals. Proc. Boston Soc. Nat. Hist., vol. 28, 1899.

GreEn, H. A. On a few fossil localities of Livingston and Genesee counties, N. Y. Am. Jour. Sci., 2d series, vol. 41, pp. 121 and 123, 1866.

HALL, JAMES, and ClaRke, J. M. Handbook of Brachiopoda, pts. 1 and 2, Eleventh and Thirteenth Ann. Rept. State Geol. New York, 1891 and 1892.

Paleontology of New York, vol. 7. Trilobites and other Crustacea of the Oriskany, Upper Helderberg, Hamilton, Protage, Chemung, and Catskill groups, 1888.

_ Paleontology of New York, vol. 8 (two volumes). An introduction to the study of the genera of Paleozoic Brachiopoda, 1892 and 1894.

HaLd, J TMes. Second, third, fourth, and fifth annual reports of the fourth geological district of New York, 1838, 1839, 1840, 1841. 
HALL, JAMES. Geology of New York, Part IV, 1843.

- On the parallelism of the Paleozoic deposits of North America with those of Europe. Am. Jour. Sci., 2d series, vol. 5 and vol. 7, 1849.

Paleontology of New York, vol. 4, pt. 1, containing plates and descriptions of Brachiopoda of the Upper Helderberg, Hamilton, Portage, and Chemung groups, 1867.

Paleontology of New York, vol. 5, pt. 1 (two volumes). Lamellibranchiata of the Upper Helderberg, Hamilton, Portage, and Chemung groups, 1885.

Paleontology of New York, vol. 5; pt. 2 (two volumes). Gasteropoda, Pteropoda, and Cephalopoda of the Upper Helderberg, Hamilton, Portage, and Chemung groups, 1879.

HARRIS, G. D. Notes on the geology of southwestern New York. Am. Geol., vol. 7, 1891.

KAYSER, E. Beiträge zur Kenntniss einiger palæozoischer Faunen Sud-Amerikas. Zeitschr. d. Deutsch geol. Gesellschaft, 1897.

KINDLE, E. M. The Devonian and Lower Carboniferous faunas of southern Indiana and central Kentucky. Bull. Am. Pal. No. 12, 1899.

Lincoln, D. F. Report on the structural and economic geology of Seneca County. Fourteenth Ann. Rept. State Geol. New York, 1894.

Luther, D. D. Report on the geology of the Livonia salt shaft. Thirteenth Ann. Rept. State Geol. New York, 1894.

Economic geology of Onondaga County. Fifteenth Ann. Rept. State Geol. New York, 1895 .

Macludre, William. Trans. Am. Philos. Soc., 1809.

Mutuer, S. A. North American Geology and Paleontology. (Revised to 1897.)

Prosssar, C. S. The classification and distribution of the Hamilton and Chemung series of central and western New York. Fifteenth Ann. Rept. State Geol. New York, 1895.

The thickness of Devonian and Silurian rocks of western New York. Am. Geol., vol. 6, 1890.

The Devonian system of eastern Pennsylvania and New York. Bull. 120, U. S. Geological Survey, 1894.

Devonian system of eastern Pennsylvania. Am. Jour. Sci., 3d series, vol. $44,1884$.

Rathbun, R. Devonian brachiopods from the province of Para, Brazil. Proc. Boston Soc. Nat. Hist., vol. 20, 1881.

Rominger, C. Fossil corals. Geol. Survey of Michigan, 1873-1876.

Schuchert, Charles. Synopsis of American fossil Brachiopoda. Bull. 87, U.S. Geological Survey.

Simpson, G. B. A handbook on the genera of North American Paleozoic Bryozoa. Fourteenth Ann. Rept. State Geol. New York, 1894.

Spencki, J. W. A review of the history of the Great Lakes. Am. Geol,, vol. 14, pp. 289-301.

Steinmann, Dr. G. Beiträge zur Geologie und Palæontologie von Südamerika, 1892.

Vanuxem, LaRpner. First Annual Report of the geological survey of the fourth district of New York, 1837.

Second, third, fourth, and fifth annual reports of the Geological Survey of the third district of New York, 1838, 1839, 1840, 1841.

Geology of New York, part 3, 1842.

Whiteaves, J. F. Contributions to Canadian Paleontology, vol. 1, pt. 5.

- Contributions to Canadian Paleontology, vol. 1, pt. 4.

Williams, H. S. The cuboides zone and its fauna. Bull. Geol. Soc. America, vol. 1,1890 , 
Williams, H. S. Report of the subcommittee on the Upper Paleozoic (Devonic). Am. Geol., vol. 2, 1888.

On the southern Devonian formations. Am. Jour. Sci., 4th series, vol. 3, 1897.

On the different types of the Devonian system in North America. Am. Juur. Sci., 3d series. vol. 35, 1888.

- Geological Biology. An introduction to the geological history of organisms, 1895 .

Correlation papers. Devonian and Carboniferous, Bull. 80, U. S. Geological Survey, 1891.

- On a remarkable fauna at the base of the Chemung group in New York. Am. Jour. Sci., 3d series, vol. 25, 1883.

A revision of the Cayuga Lake [New York] section of the Devonian. Am. Jour. Sci., 3d series, vol. $32,1886$.

The making of the geological time scale. Jour. Geol., vol. 1, 1892.

Southern Devonian formations. Am. Jour. Sci., 4th series, vol. 3, 1897.

Williams, S. G. The Tully limestone, its distribution and its known fossils. Sixth Ann. Rept. State Geol. New York, 1886.

— Dip of the rocks in Central New York. Am. Jour. Sci., 3d series, vol. 26, . 1888.

- A revision of the Cayuga Lake section of the Devonian. Proc. A.A.A.S., vol. 35.

Wright, B. H. Notes on the geology of Yates County, N: Y. Thirty-fifth Ann. Rept. Reg. of the Univ. on the State Cab. of Nat. Hist., 1884. 
[A = abundant. $\quad \mathrm{C}=$ common. $\quad \mathrm{Cr}=$ fairly common. $\quad \mathbf{r}=$ rare. $\quad \mathrm{R}=$ very rare. $]$.

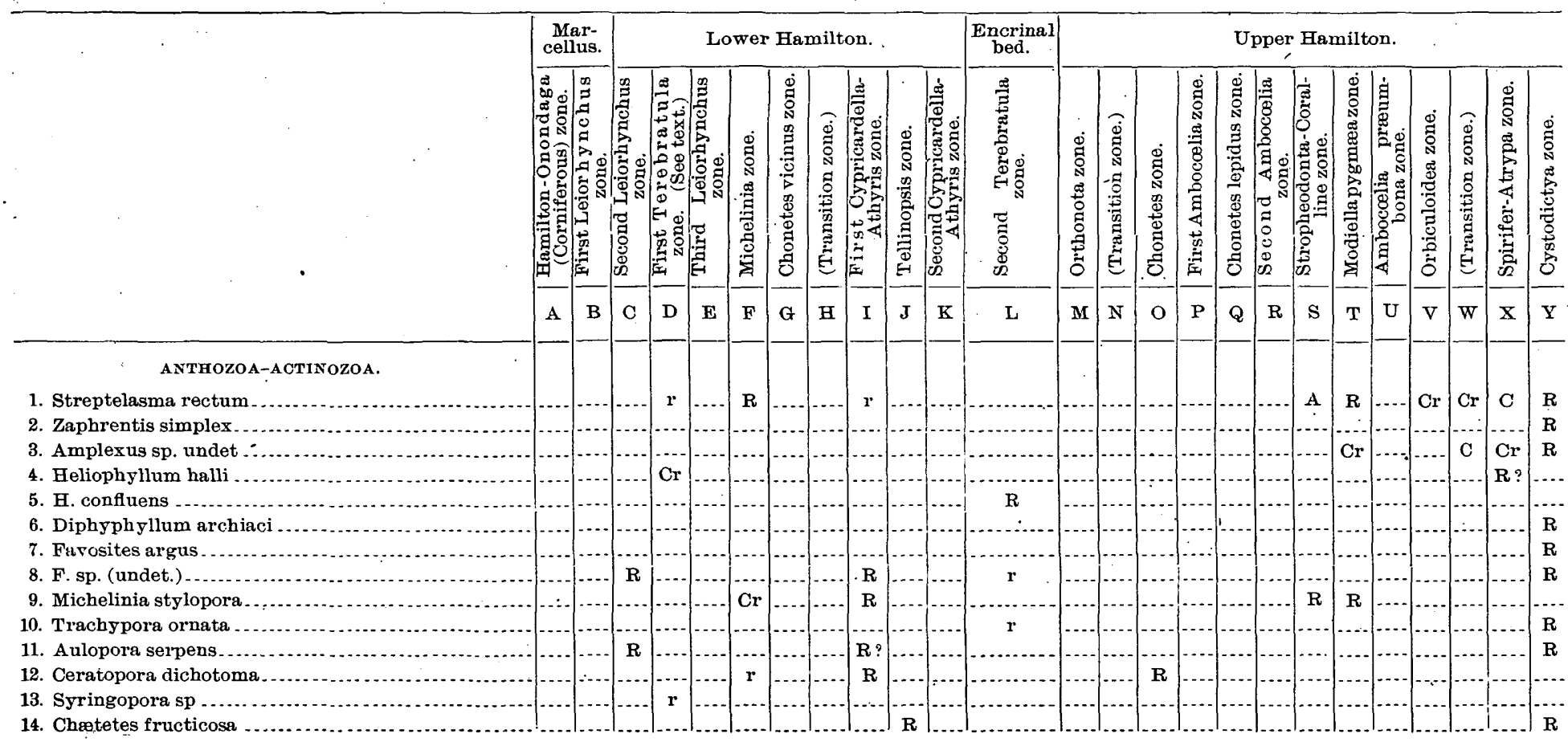



Lake, New York-Continued.

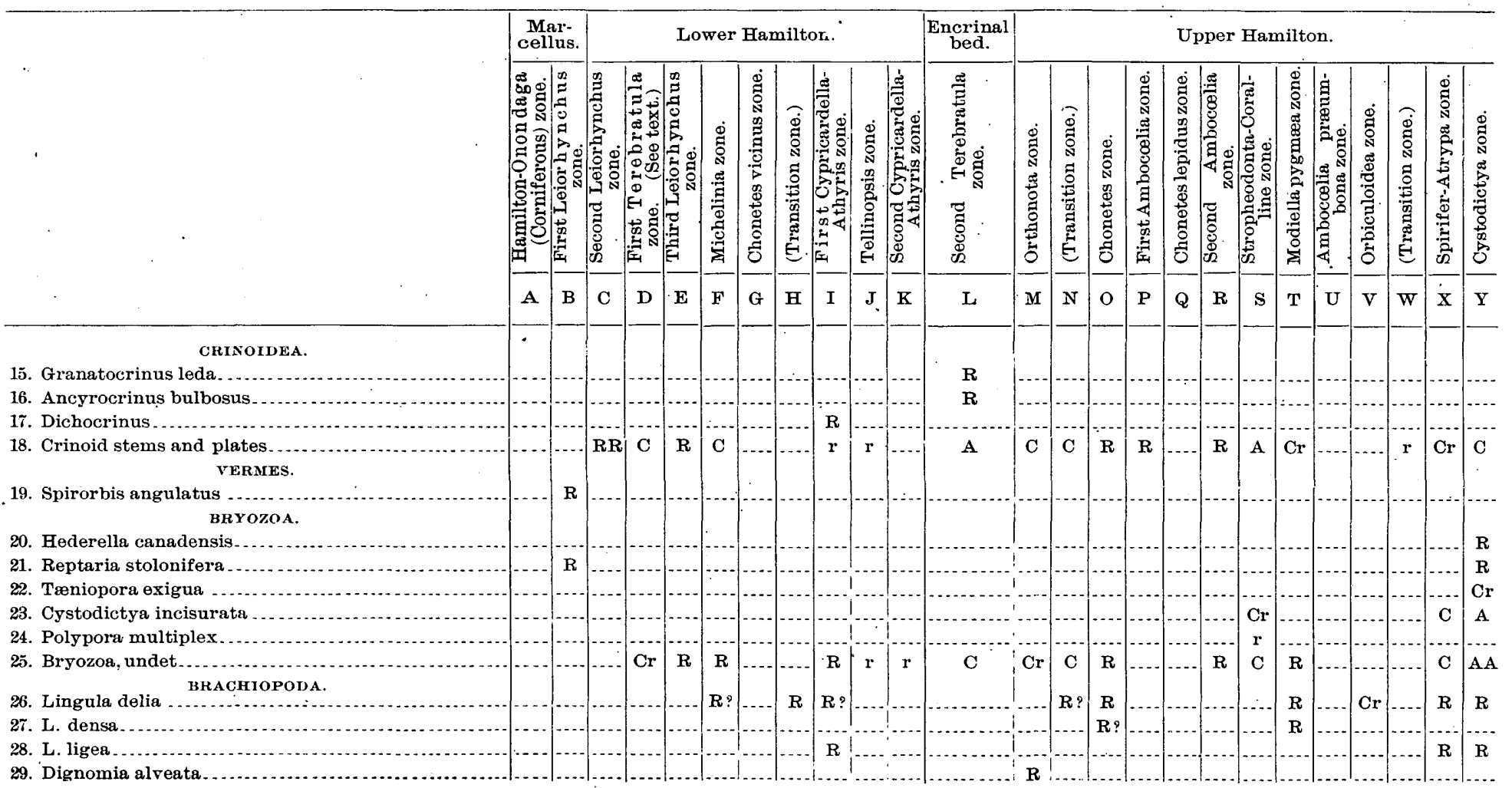


30. Camarotoechia congregata

31. C. dotis.

32. C. horsfordi

$\varpi$ 33. C. prolifica

$\Xi 34$. C. sappho

35. Hypothyris cuboides

$$
\text { - }
$$

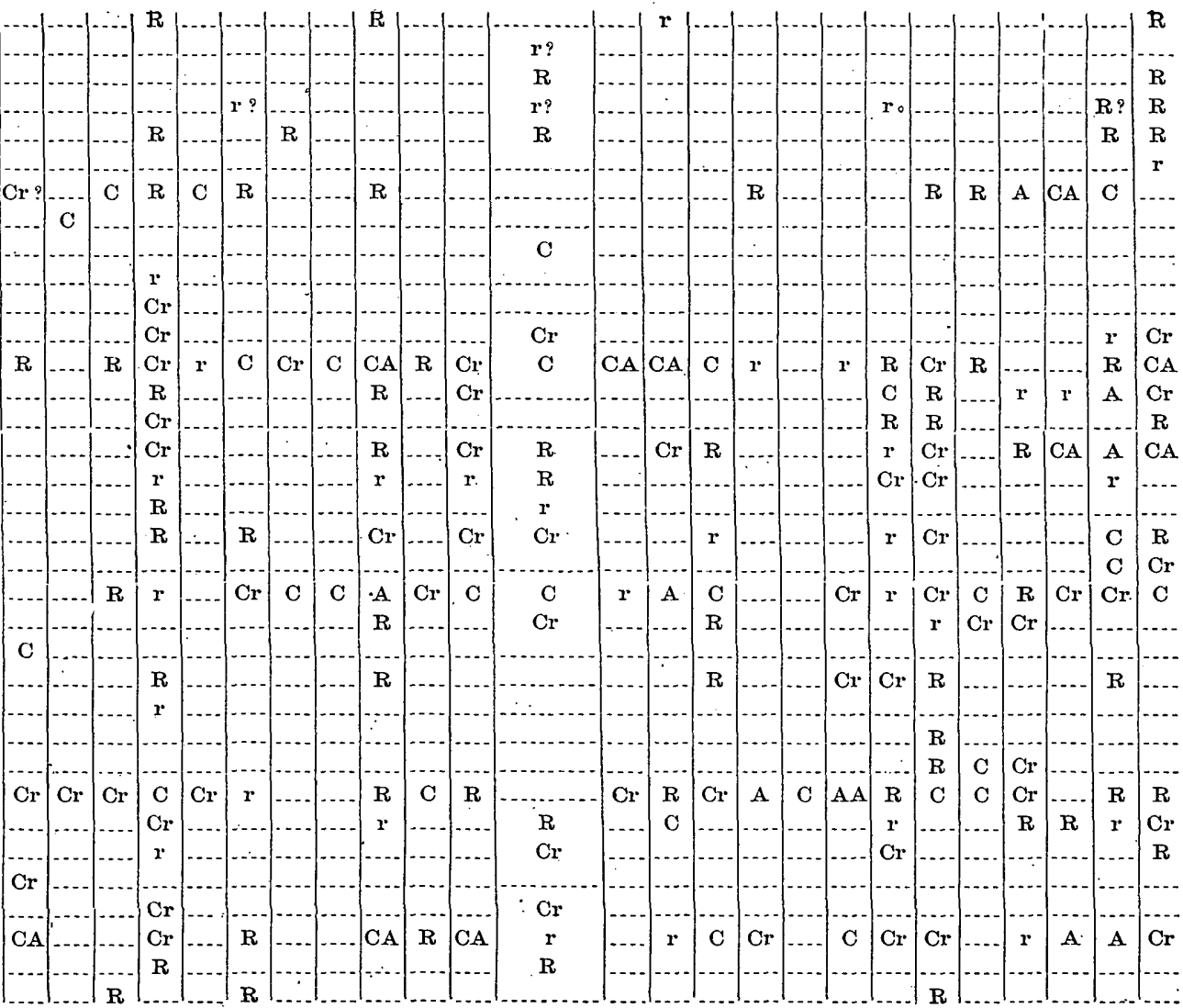

bana

1N 36. Leiorhynchus laura

37. L. limitare

38. Centronella impressa.

을 39. Cryptonella planirostris

41.

42. Tropidoleptus carinatus.

43. Atrypa reticularis.

44. Cyrtina hamiltonensis

45. Spirifer audaculus.

46. S. audaculus macronotus

47. S. divaricatus

48. S. granulosus

49. S. marcyi.

50. S. pennatus

51. S. tullius

52. S. macrus

53. Delthyris consobrin

54. D. sculptilis

55. Martinia subumbona

56. Amboccelia præumbona

57. A. umbonata

58. Reticularia fimbriata

59. Nucleospira concinna

60. Anoplotheca camilla

61. Vitulina pustulosa

62. Athyris spiriferoides

64. Orbiculoidea doria 

Lake, New York-Continued.

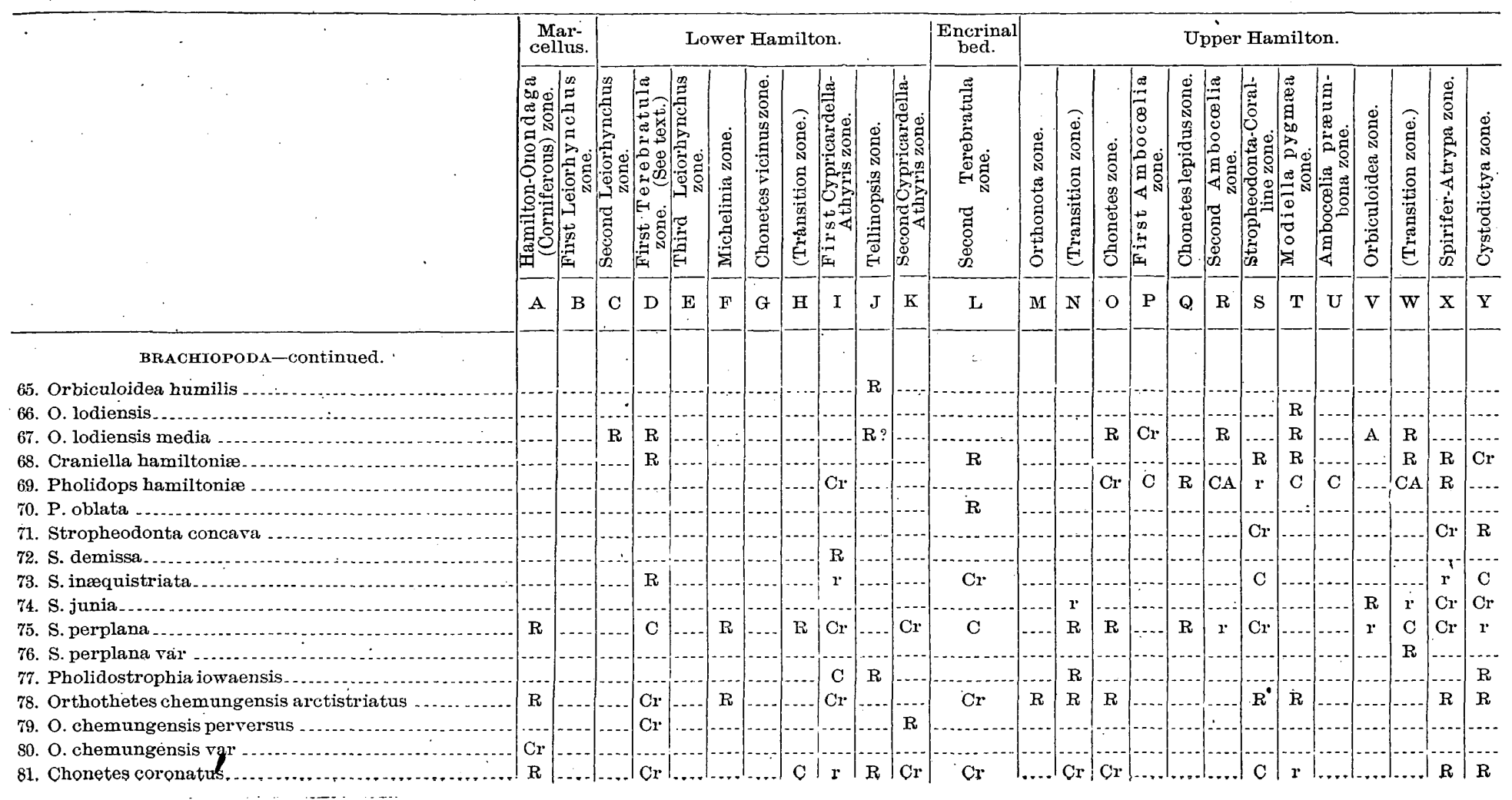


82. C. lepidus

83. C. lineatus .

84. C. mucronatus

85. C. scitulus.

86. C. setigerus

\begin{tabular}{c|c|c|c|}
$C$ & & $R$ & $R$ \\
$C A$ & $C$ & $r$ & $C A$ \\
\hdashline & $r$ & $R$ & \\
\hdashline & & \\
\hdashline & & $R$ \\
\hdashline
\end{tabular}

87. C. vicinus

87a C. sp -.

88. Productella spinulicosta

89. P. navicella

90. Strophalosia truncata

91. Rhipidomella vanuxemi

92. R. cyclas

93. R. penelope

93a. Pentamerella pavilionensis PELECYPODA.

94. Phthonia nodicostata

95. P. cylindrica

96. P. sectifrons

97. Orthonota carinata

\begin{tabular}{l|l|l|l}
$\mathrm{R}$ & $\mathrm{R}$ & $\mathrm{Cr}$ \\
& $\mathrm{R}$ &
\end{tabular}

\begin{tabular}{c|c|c|c|c|c}
$\mathrm{C}$ & $\mathrm{r}$ & $\cdots$ & $\mathrm{R}$
\end{tabular}

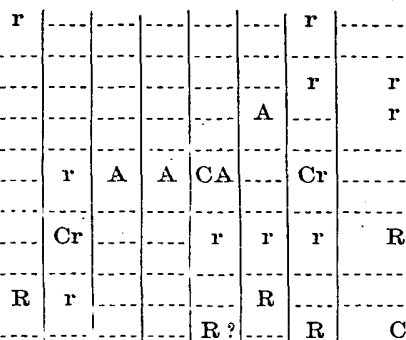

98. O. undulata

99. O. parvula

100. Prothyris lanceolata

101. P. truncata . ..........

102. Grammysia constricta

103. G. cuneata

104. G. arcuata

105. G. bisulcata

106. Elymella fabalis

107. E. nuculoides

108. Glossites subtenuis

109. Tellinopsis subemarginata

110. Panenka lincklæni

111. P. potens

112. P. sp.

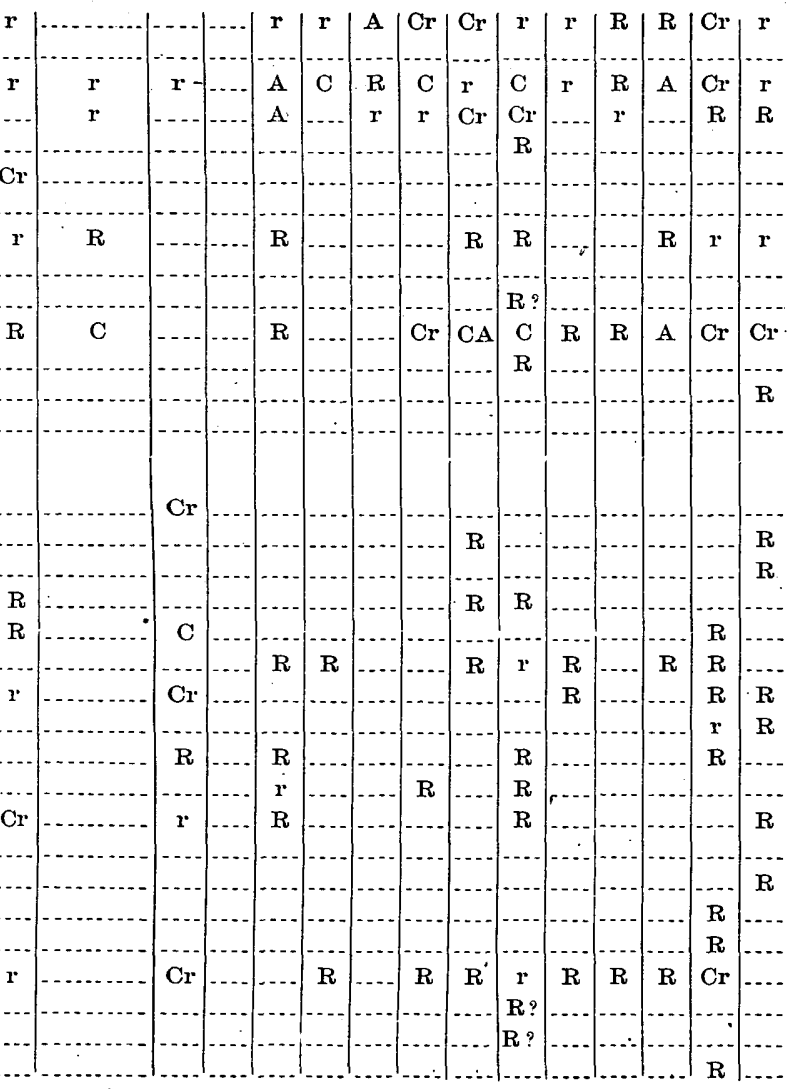




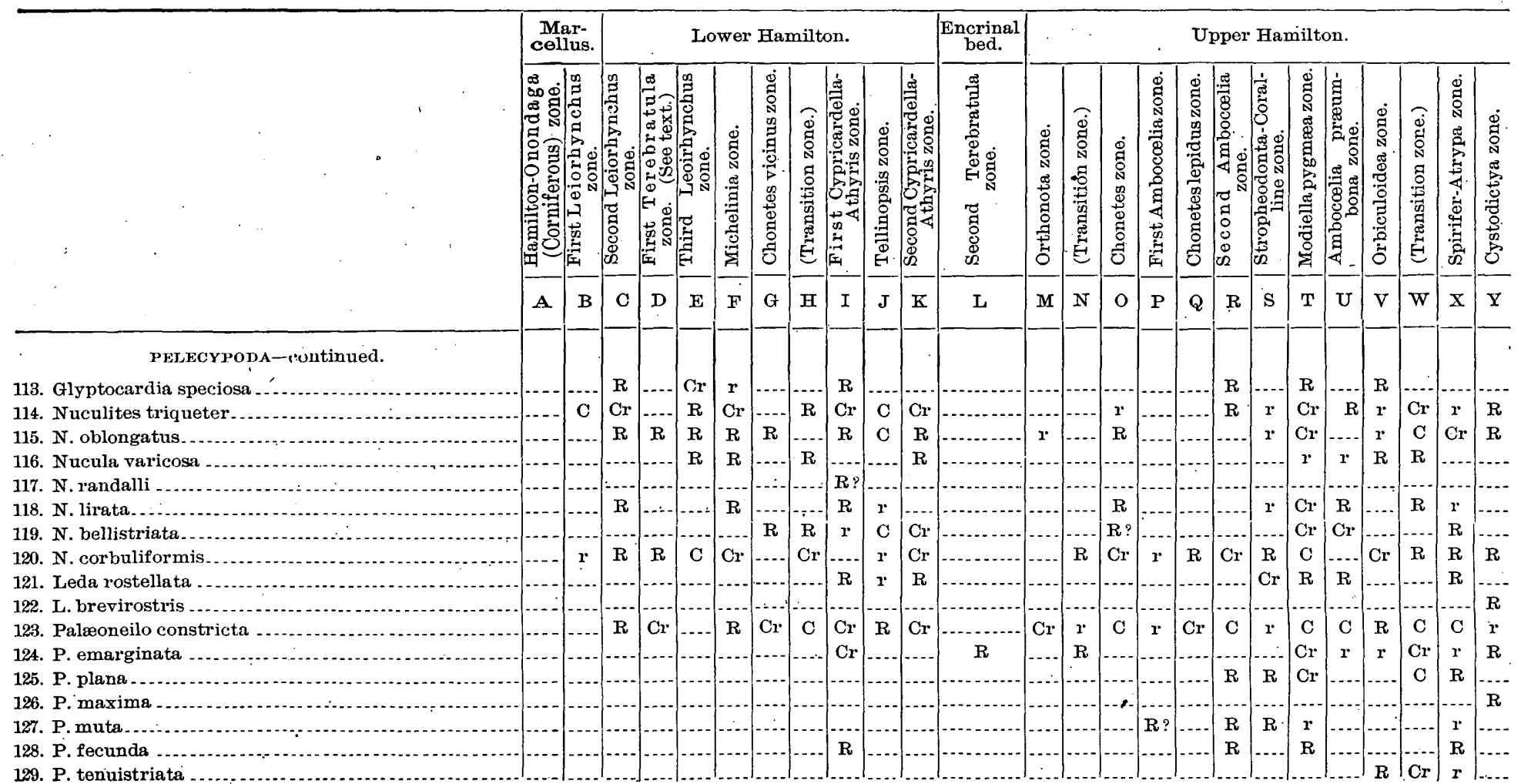


130. Parallelodon hamiltoniæ

131. Sphenotus arcæformis

132. S. cuneatus

133. S. solenoides .

134. Pterinea flabella.

135. Lunulicardium fragile

136. L. curtum.

137. L. ornatum

138. Plethomytilus oviformis

139. Mytilarca gibbosa

140. Spathella typica.

141. Conocardium normale

142. Actinopteria boydi

143. A. decussata

144. A. subdecussata

145. Leiopteria greenı

146. L. lævis

147. L. rafinesquii

148. L. gabbi.

149. L. sayi.

150. L. conradi
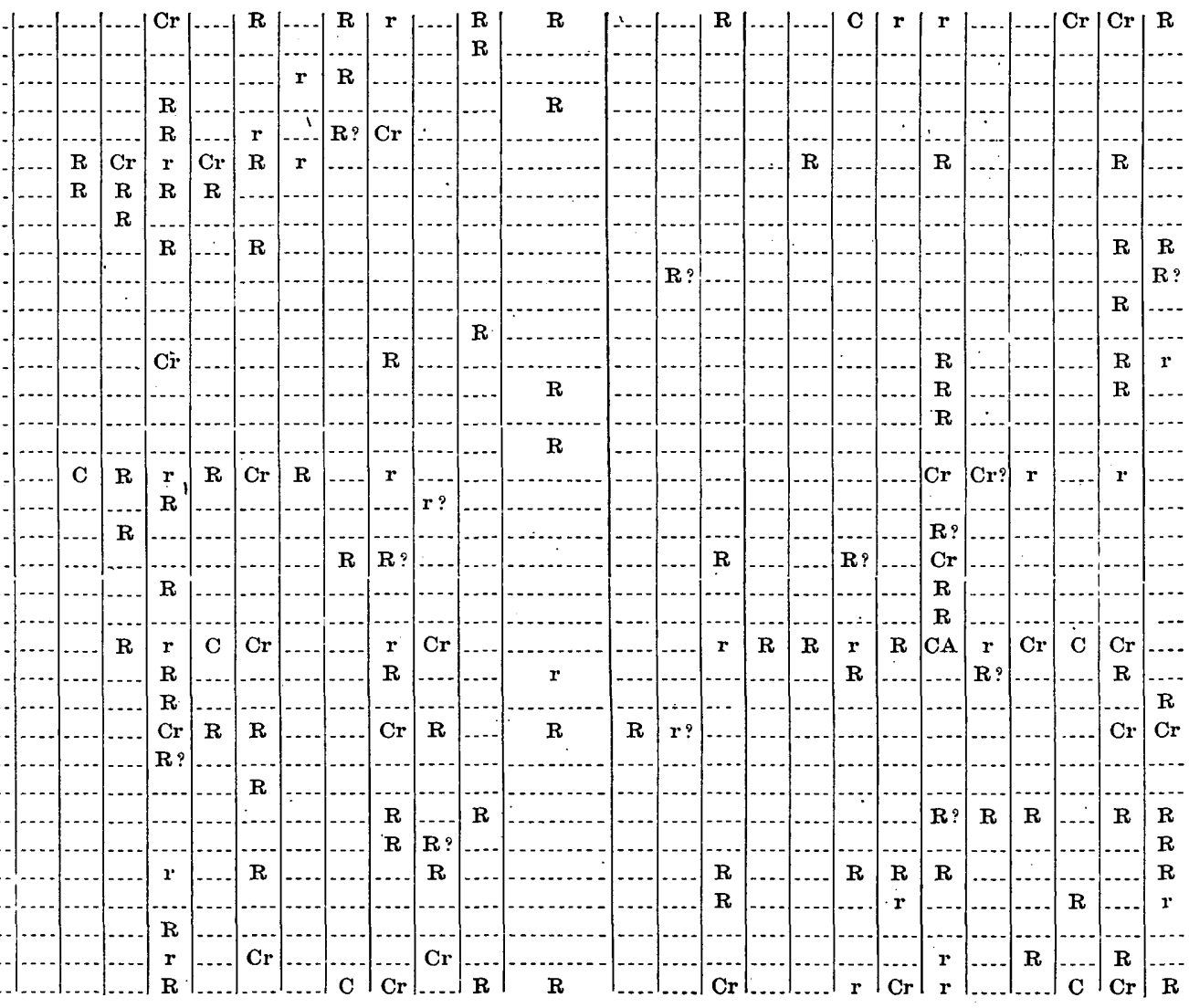

151. L dekayi

152. Modiella pygmæa

153. Schizodus appressus

154. S. contractus.

155. Aviculopecten princeps

156. A. fasciculatus

157. A scabridus

158. Pterineopecten undosus

159. P. vertumnus

160. P. intermedius

161. P. hermes

162. Lyriopecten orbiculatus

C $\mathrm{Cr}$.... $\mathrm{R}$

$\mathbf{R}$

$\mathrm{Cr}$

163. Modiomorpha 
A.PPENDIX.-Tabie showing vertical distribution of faunal zones, with their contained faunules, in the Hamilton formation of Cayuga Lake, New York-Continued.

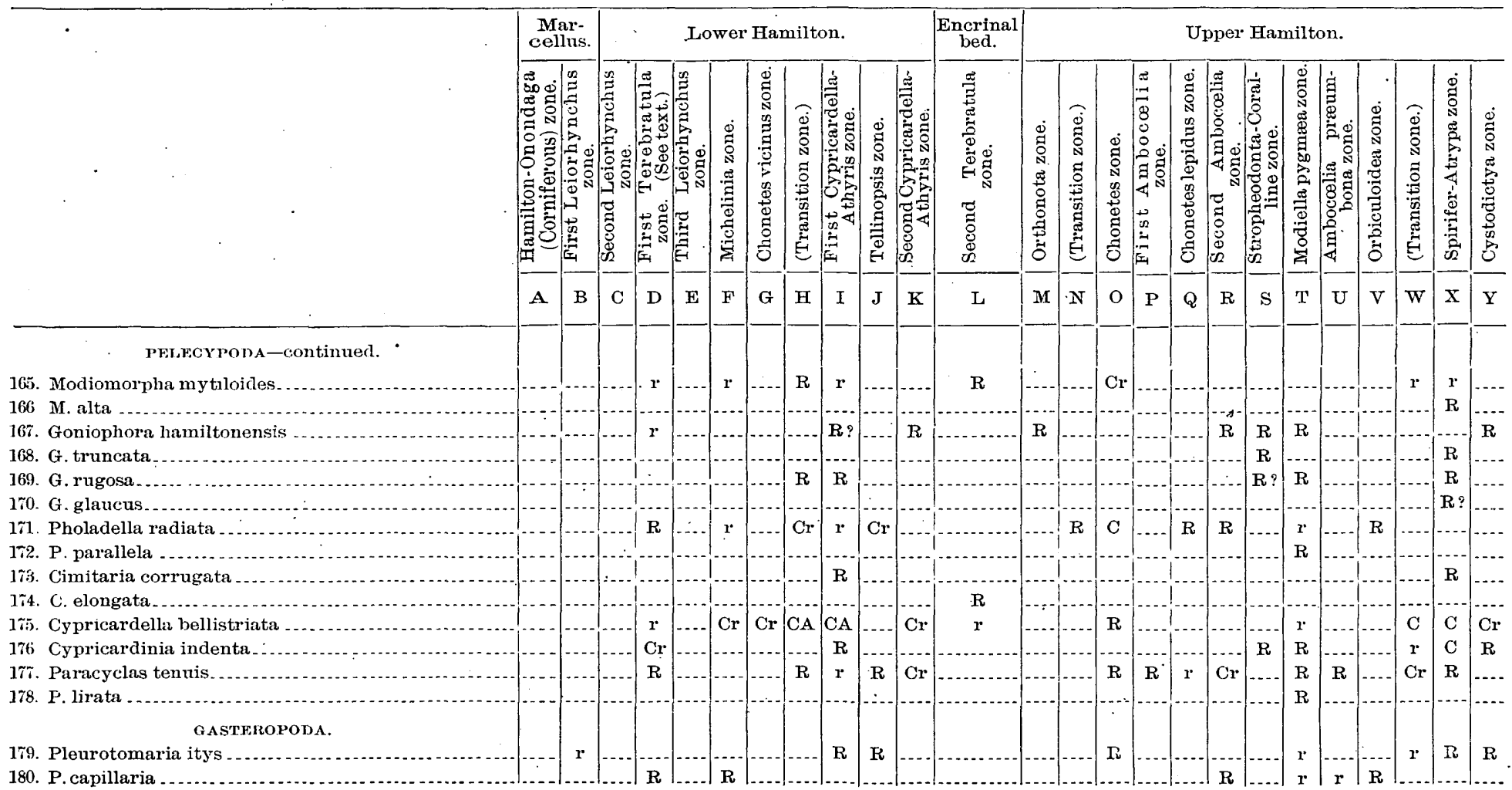


181: P trilix.

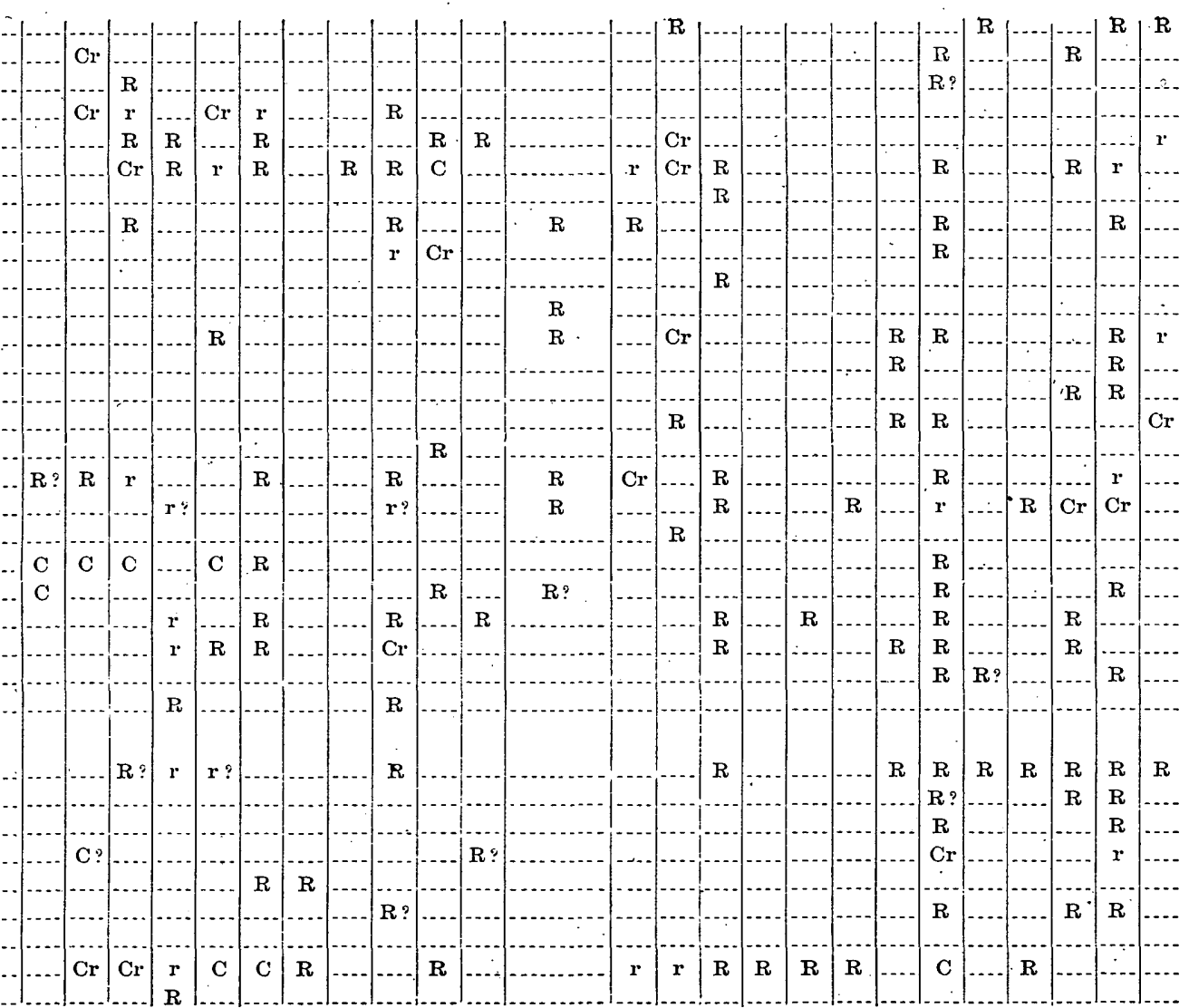

183. P. rotalia

184. P.rugulata .

185. Bellerophon patulus

186. B. leda

187. B. lyra

188 B crenistria.

189. Cyrtolites mitell

190. Euomphalus sp

191. Platyceras conicum

192. P. erectum

193: P. bucculentum

194. P. carinatum

195. Platyostoma lineata

196. P. varians ..............

197. Loxonema hamiltoni

199. Callonema imitator

200 Styliola fissurella.

201. Tentaculites bellulus

2012. Coleolus tenuicinctum

203. Hyolithes aclis

204. H. striatus

205. Conularia undúlata.

206. Orthoceras crotalum

207. O. cælamen

208. O. nuntium

209. O. subulatum

210. O. constrictum

211. O. exile.

212. O. marcellense

213. O. sp. undet

214. Nautilus liratus juvenis

\section{CEPH A LOPODA}

in-

.......

(n............

(n)

(n)

(n)

A.

(1)

.

..

\begin{tabular}{cc|c|c|c|c}
$C r$ & $C r$ & $r$ & $C$ & $C$ & $R$ \\
$R$ & &
\end{tabular} 


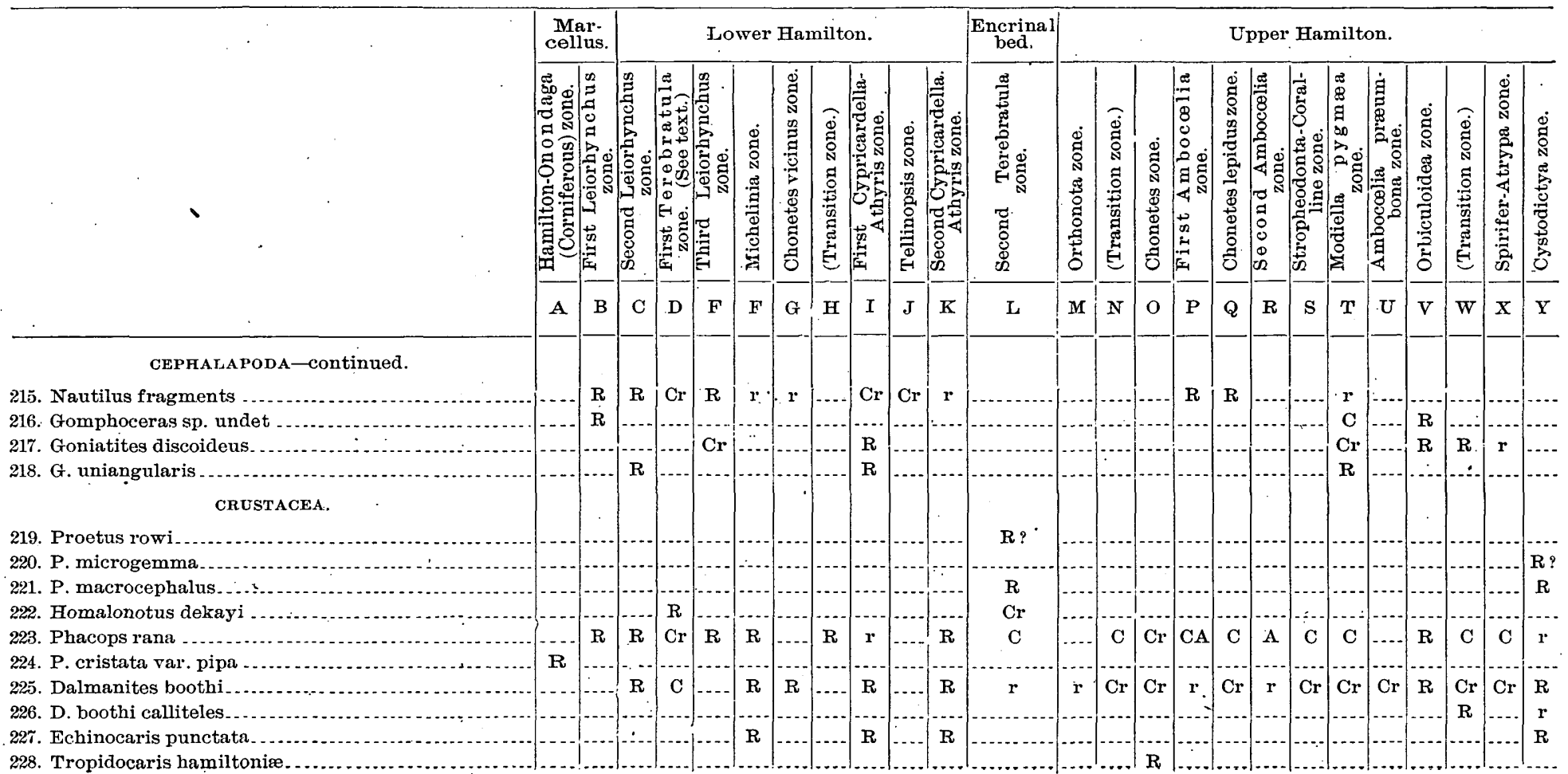


229. Rhinocaris sp -

230. Mesothyra oceani.

231. Ostracods sp, undet

PLANTa.

232. Lepidodendron gaspianum

233. Plant fragments

234. Taonurus.

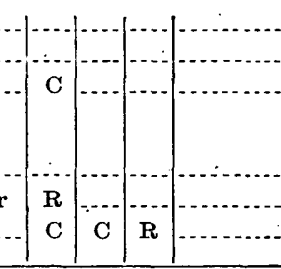





\section{N D E X .}

Names in italic are synonyms; flgures in black-face type are numbers of pages containing description or classiflcation.

A. $\quad$ Page.

Actinopteria Hall ......................

boydi Conrad. ..................... 6ī,101

decussata Hall ......................67,101

subdecussata Hall. ................ 67,101

Ambocolia Hall ...... . . ... . . . . . . . . . . .... 48-49 præumbona Hall................. 30, 48, 86, 97 umbonata Conrad ................... 22, $23,27,28,29,30,32,49,83,97$

Ambocclia zone, first, description of .... $\quad 28$

Amboccelia zone, second, description of .. $\quad$ gs

Ambocœlia præumbona zone, description of.

Ambonychiidø Miller.

Ammonoidea

30

Amplexus Sowerby ..................... 35 sp. undet. ..................... 29, 35,95

Anatinacea Dall ...................... 71-72

Ancyrocrinus Hall ...................... 38 bulbosus Hall. . . . . . . . . . . . . . . . .... 38,96

Anomalodesmacea Dall ................. 71-72

Anoplotheca Sandberger . . ............. 50 camilla Hall. .................... $22,50,86,97$ flabellites ............................ 44

Anthozon-Actinozoa ................. 35 50-38,95

Arthropoda...................... $79-81$

Aspidobranchia Schweigger............ 73-74

Athyridæ Phillips...................... 49-51

Athyrinæ Waagen ...................... 51

Athyris McCoy................. spiriferoides Eatoin ............ 26,31, 51,97

Atremata Beecher .................... 40-41

Atrypa Dalman .................... 4i reticularis Linnæus ........... 29, 31, 45,97

Atrypide Gill....................... 45

Atrypinæ Waagen ..................... 45

Aulopora Goldfuss ..................... serpens Goldfuss...................... 37,95

Auloporidæ Nicholson...................

Aviculopecten McCoy .................... 69:70 fasciculatus Hall.................. 69, 101 princeps Conrad .................. 69, 101 scabridus Hall ....................... (69, 10]

B.

Basal limestone; description of ........... 83-84

Bellerophon de Montfort

crenistria Hall ...................... 74,103

leda Hall ............................ 74, 103

lyra,............................... 74,108

patulus Hall........................ 74,103

Bellerophontidre McCoy.................

Bibliography ..........

Bishop, I. P., correlation by ............. $\quad 84$
Page.

Brachiopoda ._. 40-5\$, 86, 87, 89, 96

Bryozoa Ehrenberg . . . . . . ............ 39-40,96

sp. undet . . . . . . . . . . . . . .

C.

Callonema Hall......................... 76 imitator Hall and Whitfield......... 76,103

Camarotœchia Hall and Clarke.... . .... 41-42

congregata Conrad.................. 41,97

dotis Hall........................... 41,97

horsfordi Hall...................... 41,97

prolifica Hall . ........................ 41,97

sappho Hall ..... . ...................... 42,97

Capulidæ Cuvier..........................

Cardiolidæ Neumayr .................. $\quad 62$

Cavoliindø Fischer ...................... $\quad 76$

Cayuga Lake region, general description of . . . . 13-14

section of 14

comparison of, with other sections of Hamilton formation........ 83-88

time represented in formation of. $\quad 90$ zones in, figure showing ............. 21

Centronella Billings :.................... 43 impressa Hall ................... 27, 43,84,97

Centronellidæ Hall and Clarke.......... 43

Cephalopoda ......................... $77-79,108$

Ceratiocarina Clarke .................. \$1

Ceratopora Grabau . ..................... 37

dichotoma Grabau................ 25,87,95

Chætetes Fischer....................... 3s

fructicosa Hall . ...................... 38,95

Chætetidæe E.\& H. ................... 38

Chonetes Fischer de Waldheim....... 28, 5ij-57 coronatus Conrad. ...................5, 98 deflecta Hall . . ......................... 53 lepidus Hall..................... 28, 55 -56,99 lineatus Conrad.................. 22, 56,99 mucronatus Hall. $22,24,26,28,29,30,31,56,99$ scitulus Hall .................. 27,28, $\mathbf{5 6}, 99$ setiger.us Hall . ...................... 56,99 vicinus Castelnau ........... 26,27, 56-57,99

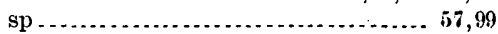

Chonetes zone, description of ........... 28

Chonetes lepidus zone, description of .... $\quad 28$

Chonetes vicinus zone, description of..... 26

Chonetinæ Waagen ..................

Cimitaria Hall ....................... 71-72 corrugata Conrad.................. 81,102 elongata Conrad ................. 72,102

Clarke, J. M., citad on locality of first terebratula zone .............. 24 description of Basal limestone by .... $\quad 83$ quoted on Ambocolia spinosa ........ 49 
Page.

Coal, search for

Colenterata

...-30-38

Cœleospira camilla ....................... · 50

Coleolus Hall

tenuicinctum Hall

77,103

Conocardiidæ Neumayr ................ 67

Conocardium Bronn . .................. 67 normale Hall . . ...................... 67,101

Conrad, T. A., geological work by ........ 18

Conularia Miller........................ 78 undulata Conrad.

Conularida Miller and Gurley .......... 76-77

Corals

Corniferous zone. Sẹe Onondaga-Hamilton zone.

Correlation, early attempts at

Craniacea Waagen

Craniella Oehlert

hamiltoniæ Hall

$52-53$

$52-53$

52,98

Craniidæ King

Crinoid stems

Crinoid stems and plates

Crinoidea Miller

38,96

Crustacea

79-81, 89, 10

Cryptonella Hall

lincklcen $i$ Hall

planirostris Hall

$24,43,97$

rectirostris Hall.

$24,43,97$

Cryptostomata Vine ................... 39-40

Ctenobranchiata Schweigger ........... 75-76

Ctenodontidæ Dall ...................... 62-63

Cyathophyllidæ E. \& H. .................. $\quad 36$

Cyathophylloid corals.................... 85

Cyclostomata Busk ...................... $\quad 39$

Cypricardella Hall ..................... 72 bellistriata Conrad ........... 25,26, 72,102

Cypricardella bellistriata-A thy ris Spiriferoides zone, first, description of

Cypricardella bellistriata-Athyris Spiriferoides zone, second, description of...

Cypricardiacea Dall

Cypricardinia Hall . indenta Conrad ................... 72,102

Cyrtina Davidson . .................... 45 hamiltonensis Hall.................. 45, 97

Cyr tochoanites Hyatt................... 79

Cyrtolites Conrad ....................... 74 mitella Hall ....................... 74,103

Cystodictya Ulrich incisurata Hall ....................

Cystodictya zone, description of ......... 31-32

Cystodictyonidæ Ulrich................... $\quad 39$

Cystophyllum americanum............. 24

\section{D.}

Dalmanites Emmrich ................... $\quad \mathbf{8 0}$ boothi Green ....................... 31,80 var. calliteles Green . . . . . ......... 80,104

Delthyris Dalman ....................... 48 consobrina d'Orbigny ............. 47,48,97 sculptilis Hall ........................ 48,97

Diastoporidæ Busk . ...................

Dichocrinus Münster . . .................. 38,96 sp.? ................................... 38
Page.

Dignomia Hall ......... 41 alveata Hall ....................... 41,96

Diphyphyllum Lonsdale ................. $\quad 36$ archiaci Billings ..................... 36,95

Discina doria ........................... 51 humilis ..................... 51

lodensis ................................. 52

Discinacea Waagen .................. 51-52

Discinidø Gray ..........................

E.

Eaton, Amos, geological work of ........ 17,18

Echinocaridæ Clarke $\quad 81$

Echinocaris Whitfield................. 81 punctata Hall ..................... 81,104

Echinodermata . .......................... 38

Elymella Hall ......

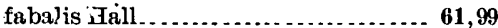

nuculoides Hall .................... 61,99

Encrinal beds, extent of .................. 15

faunules of, comparison of . .......... 84-85

Eucrustacea Kingsley................... $\quad 81$

Eunella Hall and Clarke ................ 44 lincklæni Hall.............. 24, 27,43, 44,97

Euomphalidæ de Koninck ................ 74

Euomphalus Sowerby ................. 74 sp ................................

Eurycampyli Hyatt.................... 79

F.

Faunal zones, table showing vertical distribution of, with their contained faunules. ............. 95-105

Favosites Lamarck .................... 24, 36,83 argus Hall. . ..... . . . . . . . . . . . . . . 36,95

sp. undet .......................... 36,95

Favositidæe E. \& H...................... 36-37

Fenestellidæ King..................... 40

Fossiliferous zones, descriptions of....... 20-34

figure showing ......................... 21

Fossils of Hamilton stage throughout New York State, diagram showing distribution of....... 87

G.

Gasteropoda ................. 73-77,85,87,102

Glossites Hall ........................... 61 subtenuis Hall ...................... 61,99

Glyphioceratidxe ...................... 79

Glyptocardia Hall......................... 62 speciosa Hall ....................... 62,100

Gomphocerws Sowerby $\ldots \ldots \ldots \ldots$

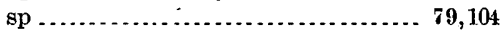

Goniatites do Haan.................... 79

discoidsius Hall. ..................... 79,104 uniangularis Conrad. .............. 79,104

Goniophora Phillips..................... 70-71

glaucus Hall .......................

hamiltonensis Hall.................. 70,102

rugosa Conrad ..................... 71,102

truncata Hall ....................... 71,102

Grammysia de Verneuil ................. 60-61 arcuata Conrad . . .................. 61,99 bisulcata Conrad ..................... 61,99 constricta Hall .................... 25, 60,99 cuneata Hall ........................ 61,99

Grammysiidæ Fischer ................... 60-61

t

31

(1)

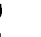


Page.

Granatocrinus Troost................... 38

(Pentremilis) leda Hall............... 35,96

Gymnoglossa . ........................ 75-76

Gymnolæmata Allman. ................. 39-40

H.

Hall, James, geological work by quoted on Ambocœl:a umbonata ..... quoted on Encrinal beds

quoted on fossils of Hamilton formation

Hamilton fauna, use of terms "Upper" and "Lower"

Hamilton formation, couclusions relative to fossil faunules in

extent and character of

faunal zonesin, table showing vertical distribution of, with their contained faunules.

history of . thickness of.

Hamilton stage, fossils of, diagram showing distribution of..............

Hamilton-Onondaga zone, description of. 20-22 faunule of

Hederella Hall

canadensis Nicholson ................ 39,96

Heliophyllum Hall ......................... 36,83 confluens Hall. ................. 24, 36, 84,95 halli $\mathrm{E} . \& \mathrm{H} \ldots \ldots \ldots \ldots \ldots \ldots \ldots .24, \mathbf{3 6}, 84,95$

Hexacoralla Haeckel ................... 36-38

Hindellinæ Schuchert..... . ............... 49-51

Homalonotus Köenig. .................... S0

dekayi Green...................... 80, 104

Hyolithes Eichwald. ....................

aclis Fiall ............................ 77,103

striatus Hall ...................... $7 \mathbf{7 7 , 1 0 3}$

Hyolithidæ Nicholson ...................

Hypothyris King ........................ $4 \mathbf{4 2}$

cuboides Sowerby.................. 42,97

J.

Jointing in the region.

$\mathrm{K}$.

King Ferry, concretionary layer's at.....

L.

Lake Ridge, concretionary layers at.....

Leda Schumacher

rostellata Conrad

Ledidæ Adams . .......................... 64-65

Leiopteria Hall ...................... 30,67-68

conradi Hall........................ 68,101

dekayi Hall. ........................ 68,101

gabbi Hall ........................... 67,101

greeni Hall ........................ 67,101

levis Hall ........................... 67, 101

raflnesquii Hall .................... 67,101

. sayi Hall............................ 68,101

Leiorhynchus Hall . . ................... 49-43

dubium Hall

laura Billings ........... 15, 30,31,33,42,97 limitare Vanuxem ......... 23,33,42,43,86,97 multicosta Hall .

Leiorhynchus fauna, composition of ......
Leiorhynchus zone, first, description of .. 22-23

Leiorhynchus zone, second, description of 23

Leiorhynchus zone, third, description of . $\quad 25$

Lepidodendron Sternberg ................ $\quad 82$ gaspianum Dawson ................... 82,105

Limestone, Basal, description of .......... 83-84

Lincoln, D. F., cited on locality of first terebratula zone.............. 24 used ter'm "Basal Hamilton "......... 83

Lingula Bruguière ....... . . . ............. 40-41

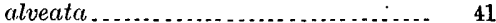
delia Hall.......................... 40,96 densa Hall. . . . . . . . . . . . . . . . . . . ..... 41,96 ligea Hall............................. 41,96

Lingulacea Waagen . . . . ................ 40-41

Lingulida Gray ......................... 40-41

Literature, bibliograply of . . . . .......... 92-94

Loxonema Phillips . ...................... 75-76 delphicola Hall, . . ...... . . .......... 75, 76,103 hamiltoniæ Hall ................... 75,103

Lucinacea Anton ...................... 72-73

Lucinidæ Fleming........................ 72-73

Lunulicardiidæ Fischer. .................. $\quad 66$

Lunulicardium Münster . ...... . .......... curtum Hall ........................... 66, 101 fragile Hall ....................... 26, 66,101 ornatum Hall ..................... 66,101

Lyolit hes Eichwald . . ..................... 77

Lyriopecten Hall ....................... 70 orbiculatus Hall ................... 70,101

M.

McClure, William, geological work by... 17 Macrodon hamiitonixe ...................... 65

Malacostraca Latre:lle.................. 81

Marcellus shale, description of ........... 22-23

Martinia McCoy ........................ 48 subumbona Hall ..................... 48,97

Megalanterinæ Waagen ................ 43

Meristella Hall .......................... 51 haskinsi Hall................... $84, \mathbf{5 1}, 84,97$

Meristellinæ Waagen ................... 51

Mesothyra Hall and Clarke.............. 81 oceani Hall .......................... $\$ 1,105$

Michelinia de Koninck .................. 25, 37 stylopora Eaton. ................... 25, 37,95

Michelinia zone (provisional), description of $\ldots$ (p........................... 25

Microdon bellistriatus ................... 72

Modiella Hall . .......................... 30,68 pygmæa Conrad ..................... 68,101

Modiella pygmæa zone, description of..... 30

Modiolopsidæ Fischer ................ 70-71

Modiomorpha Hall .................... 27, 70 alta Conrad ...................... 70,102 concentrica Conrad ................ 70,101 mytiloides Conrad .................. 70,102 subalata Conrad ..................... 70,101

Mollusca ............................ 59

Molluscoidea............................ 39-58

Myalinidæe Frech ........................

Mytilacea Ferussac ..................... $70-71$

Mytilarca Hall.......................... 66 gibbosa Hall ...................... (36, 101

\section{N.}

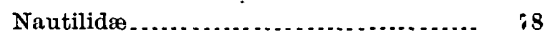

Nautiloidea ......................... $7 \mathbf{7 - 7 9}$ 


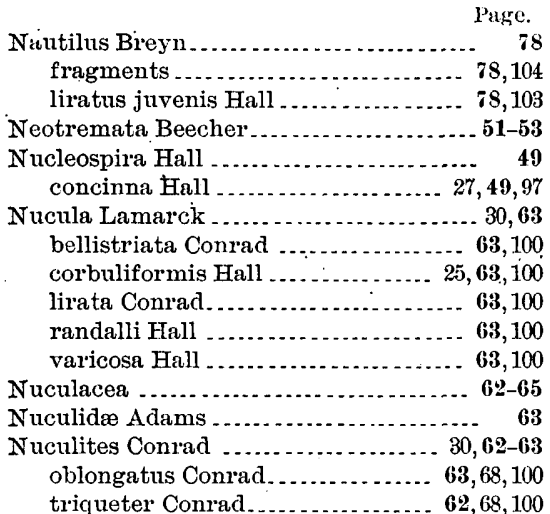

\section{O.}

Onondaga-Hamilton zone . ............... 20-22 Ontario County, Basal limestones of, description of

Opisthobranchia Milne-Edwards

Opisthoparia Beecher ...

Orbiculoidea d'Orbigny

doria Hall

humilis Hall

lodiensis Vanuxem. medin Hall

Orbiculoidea or modified Leiorhynchus zone, description of ........... 30-31.

Orthidw Woodward....................... 58

Orthis vanuxemi ........................ 58

Orthoceras Breynius ................... 77-78

crelamen Hall .................... 78, 103

constrictum Vanuxem............. 78,103

crotalum Hall . . ..... . . . . . . . . . . . . . . . 7 7,103

exile Hall .......................... 78,103

marcellense Vanuxem . . ............. . 78,103

nuntium Hall ........................ 78,103

subulatum Hall ................... 78,103

sp. undet ............................ 78,103

Orthoceratidæ .......................... 77-78

Orthoceratites..................... 23,33,89

Orthochoanites Hyatt .................. 77-78

Orthonota Conrad ..................... 59-60

carinata Conrad .................. 59-60,99

(?) parvula Hall ...................... (60,99

undulata Conrad................... $77,60,99$

Orthonota zone, description of .......... $\quad-27$

Orthothetes Fischer de Waldheim ...... 5.t-55 chemungensis var. arctistriatus

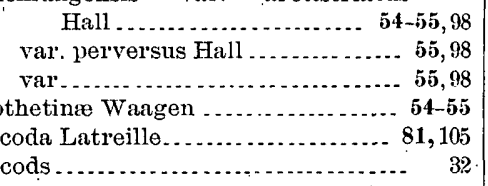

P.

Palæoneilo Hall . . ................... 30, 64-65 constricta Conrad ......... 28,29,32, 64, 100

emarginata Conrad.................. 64, 100

fecunda Hall ........... 65, 100

maxima Conrad. ...................... 64, 100

muta Hall ........................ . . 64, 100

plana Hall.............................64, 100
Puge.

Palæoneilo tenuistriata Hall .......... 64, 100

Panenka Barrande..................... 62

lincklæni Miller.................... 62,99

potens Hall . ......................... 62,99

sp. undet . . .......................... 62,99

Paracyclas Hall . . . . . . . . . 72-73

lirata Conrad ...................... 73, 102

tenuis Hall ......................... 72 72,102

Parallelodon Meek ...................... 65

hamiltonire Hall . . . . . . . . . . . . . . . 65, 101

Parallelodontidæ Dall ...................

Pectinacea Reeve. . ...................... 69-70

Pectinidæ Lamarck . . . . . . . . . . . . . . . . .... 69-70

Pelecypoda Goldfuss ............ 59-73, 87,89,99

Pentameracea Schuchert................. 58

Pentamerella Hall ....................... 58

pavilionensis Hall . ................. 58,99

Pentameridæ McCoy ...................... $\quad 58$

Phacopidø Salter . . . .................... $\quad 80$

Phacops Emmrich ....................... 80 cristata var. pipa Hall ...... . . ..... 22, 80,104 rana Green ......... 23, 28, 29, 31,32,49, 80,104

Pholadella Hall .......................... 71 parallela Hall ....................... $\mathbf{7 1 , 1 0 2}$ radiata Conrad. .................... 71,102

Pholadellidæ Miller …................. 71-72

Pholidops Hall ............................ 52 hamiltoniæ Hall ...... . . . . . . 28, 29, 31, 32, 52, 98 linguloides............................ 52 oblata Hall . . .... . . . . . . . . . . . . . . . 52,98

Pholidostrophia Hall and Clarke......... 54 iowaensis Owien ................... 26,54.98

Phragmoceratidx .................... 79

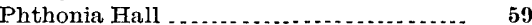

cylindrica Hall .................... 59, 99

nodicostata Hall .................. 27, 59, 99

sectifrons Conrad . ................. 59,99

Phyllocarida Packard. .................. 81

Plant fragments....................... 8*, 105

Plantre . . ................................. 82

Platyceras Conrad ....................... 75

bucculentum Hall .................. 75,103

carinatum Hall ...................... 75, 103

conicum Hall ...................... 75, 103 erectum Hall .................... 75,103

Platyostoma Conrad ................... 75 lineata Conrad................... 85, 75, 103 varians Hall ...................... 75,103

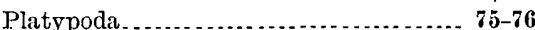

Plethomytilus Hall ..................... 66 oviformis Conrad . ................. 66, 101

Pleurophoridæ Dall . ................... 72

Pleurotomaria de France ............... 73-74 capillaria Conrad .................. 73, 102 itys Hall ......................... 73, 102 rotalia Hall ........................ 73, 103 rugulata Hall ..................... 74, 103 sulcomarginata Conrad ............. 73, 103 trilix Hall ......................... 73, 103

Pleurotomariidæ d'Orbigny . ........... 73-74

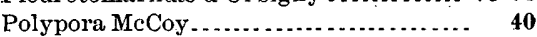
multiplex Hall ...................... 40,96

Prionodesmacea Dall. .................. 59-71

Productella Hall ...................... 57 navicella Hall

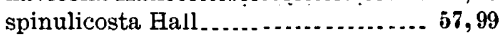
truncata ........................... 57 
Page.

Productidre Gray

Productinæ Waagen

Pröetidæ Barrande

Pröetus Steiningex

macrocephalus Hall

microgemma Hall

rowi Green.

Proparia Beecher.

Prosser, C. S., cited on Vitulina pustulosa quoted on correlation by Professor. White reference to faunal lists of

Prothyris Meek ............................ lanceolata Hall. ................... 27, 60,99 truncata sp. nov .....................60,99

Protremata Beecher ..................... 53-58

Ptenoglossa Gray ....................... 6

Pteriacen Dall ........................... 65-68

Pteriidæ Meek ............................ 67-68

Pterinea Goldfuss. ....................... 6j

flabella Conrad ..................... 65, 101

Pterineidæ Dall ............................

Pterineopecten Hall.................... 69 hermes Hall ......................... 69, 101 intermedius Hall ................... 69, 101 undosus Hall. . ..................... 69, 101 vertum.nus Hall. ..................69, 101

Pteropoda Cuvier .... $\quad \mathbf{7 6}$

Pyramidellidæe Gray ................. $75-76$

R.

Rafinesquininæ Schuchert.............. 53-55

Renevier, correlation of . ................. 19

Reptaria Rolle.......................... $\quad 39$

stolonifera Rolle..................... 39,96

Reticularia McCoy ........................ 49 flmbriata Courad .............. 49, 86,97

Rhinocardidæ Clarke.................... $\mathbf{8 1}$

Rhinocarina Clarke..................... 81

Rhinocaris Clarke....................... 81 $\mathrm{sp}$

Rhipidoglossa Troschel ................ 73-74

Rhipidomella Oehlert................. 5s cyclas Hall . . ......................... 58,99 penelope Hall ........................ 58, 99 vanuxemi Hall....... 24, 29, 31, 58, 99

Rhynchonella congregata................. dotis

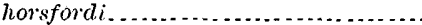

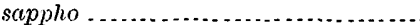

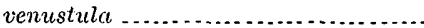
prolifica

Rhy probingellacen Schuchert.

Rhynchonellidæe Gray ............... 41-43

\section{S.}

Scalariidæ Broderip

Schizodus King. appressus Conrad contractus $\mathrm{Hall}$ 68,101

68, 101

Shurger Glen, concretionary layers at... Skaneateles Lake, coral bed near.......... Solemyacidæ Dall

Solenopsidre Neumayr . . . .................

South American Hamilton, correlation of

Spathella Hall typica Hall
Sphenotus Hall ......................

arcæeformis Hall .................. 65, 101

cuneatus Conrad................... 65, 101

solenoides Hall...................... 65, 101.

Spirifer Sowerby ....................... 45-47 audaculus Conrad ........... 31, 45,46,47,97 macronotus Hall .................. 46,97 clintoni .............................. 46 consobrinus.......................... 29 divaricatus Hall ................ 24,27,46,97 fimbriata............................ 49 granulifera Hall ..................... 46 gronulosus Conrad............ 27, 31, 46, 86, 97 macra .......... macrus Hall.................... $22,47,86,97$ marcyi Hall . ................... 31, 47,86,97

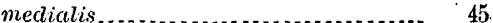
mucronata.......................... 47 mucronatus......................... 83 pennatus Atwater................... 26, 28, $29,30,31,45,47,48,97$

tullia tullius Hall ...................... 30,47,97 Spirifer-Atrypa zone, description of..... 31

Spirifera sculptilis ........................ 48 subumbona.......................... 48 ziczac ................................ 48

Spiriferacea Waagen.................... 450.51

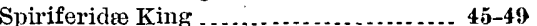

Spirorbis Daudin ......................... 39 angulatus Hall ...................... 39,96

Streptelasma Hall. ...................... 35 rectiom Hall ....................... 29, 35,95

Streptoneura Spengel.................. 73-78

Streptorhynchus chemungensis arctostriata.......................... 54

chemungensis perversus .............. 55 pectinacea ............. 55

Strophalosia King . . .................... 57 truncata Hall ................... 33, 57,86,99

Stropheodonta Hall .................... 53-54 concava Hall .................... 29, $53,86,98$ demissa Conrad .................... 53,98 inæquistriata Conrad .......... 24, 29, 53,98 junia Hall .................... 29, 31, $54,86,98$ nacrea Hall .......................... 54 perplana Conrad . ................. 31, 54,98 var .............................. 54,98

textilis

Stropheodonta-coralline zone, description of ........................... 29

Strophomenacea Schuchert............ 53-5s

Strophostylus ............................. 75

Styliola Lesueur ....................... 23,33, 76

fissurella Hall................... 21, 76,103

Syringopora Goldfuss .................... 37,84 sp. undet .......................... 37,95

Syringoporidre E. \& H ................. $\quad 37$

Suessinæ Waagen, ....................... 45

T.

Tabulata E. \& H....................... 36-38

Tænioglossa Bouvier ..................... $\quad 75$

Tæniopora Nicholson ................... 39 exigua Nicholson ................... 39,96

Taonurus ............................... 89,105

sp. ? Fischer-Ooster .................. $8 \mathbf{8 2}$ 
Teleodesmacea

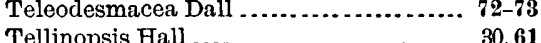
subemarginata Conrad . ....... 27,32,61,99

Tellinopsis zone, description of . . . ....... 26-27

Telotremata Beecher. 41-51

Tentaculites Schlotheim $21,23,33,76$ bellulus Hall _.... . . . . . . . . . . . . . 6,103

Tentaculitidø Walcott ................ 76

Terebratellidø King . .................... 44-45)

Terebratula zone, first, description of ... 23-24 Terebratula zone, second (Encrinal beds), description of

Terebratulacea Waagen

Terebratulidæ Gray

$43-45$

Terebratulinæ Dall

Tetrabranchiata Owen

44
$7-79$

Tetracoralla Haeckel

$\mathbf{3 5}-\mathbf{3 6}$

Torellellidæ Holm

77

Trachypora E. \& H

(Dendropora) ornata Rominger $\quad 37,95$

Trigoniacea Bronn

Trigoniidæe Lamarck .

Trigonotretinæ Schucher

Trilobita 45-49

Tropidocaris Beecher.
Page.

Tropidocaris hamiltonize Hall ........... $\mathbf{S 1 , 1 0 4}$

Tropidoleptiina Schuchert . . . . . . . ..... 44-45

Tropidoleptus Hall ........ . . . . . . . ... 26, 44-45 carinatus Conrad . ................. 19,22

$25,26,28,32,44-45,86-97$

Tubicola ............................... 39

Tully fold, extent and character of . . . . . . 15-16

V.

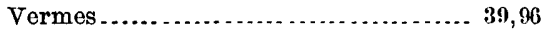

Verneuil, correlation by ............... 19

Vitulina Hall ................... pustulosa Hall ..... 19, $24,27,44,45, \tilde{50}, 84,97$

W.

\}

Williams, H.S., correlation by .......... 19

introduction by ......

letter of transmittal by .............

\section{Z.}

Zaphrentidæ E:\& H ...............

Zaphrentis Rafinesque . ................. 35 simplex Hall . . . . . . . . . . . . . . . . . 35,95

Zones, fossiliferous, descriptions of ...... 20 20-34 figure showing.................... 21 